Portland State University

PDXScholar

7-16-1992

\title{
A Classroom Preferences Questionnaire Based on the Theory of Multiple Intelligences
}

\author{
Allyn Snider \\ Portland State University
}

Follow this and additional works at: https://pdxscholar.library.pdx.edu/open_access_etds

Part of the Curriculum and Instruction Commons

Let us know how access to this document benefits you.

\section{Recommended Citation}

Snider, Allyn, "A Classroom Preferences Questionnaire Based on the Theory of Multiple Intelligences" (1992). Dissertations and Theses. Paper 4426.

https://doi.org/10.15760/etd.6304

This Thesis is brought to you for free and open access. It has been accepted for inclusion in Dissertations and Theses by an authorized administrator of PDXScholar. Please contact us if we can make this document more accessible: pdxscholar@pdx.edu. 
AN ABSTRACT OF THE THESIS OF Allyn Snider for the Master of Science in Education: Curriculum and Instruction presented July 16, 1992.

Title: A Classroom Preferences Questionnaire Based on the Theory of Multiple Intelligences.

\section{APPROVED BY THE MEMBERS OF THE THESIS COMMITTEE:}

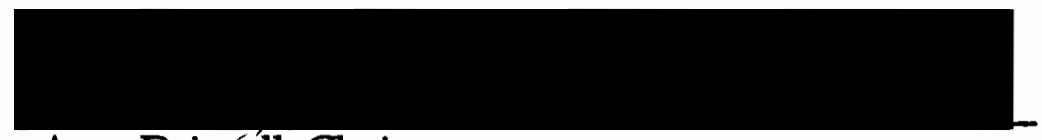

Amy Driscóll, Chair

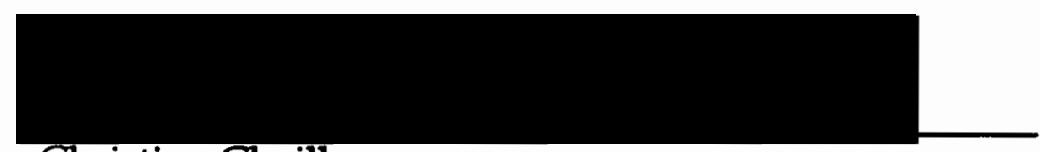

Christine Chaille

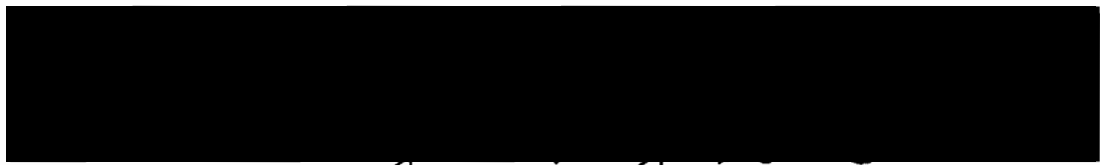

Rosemary Wray Wflliams
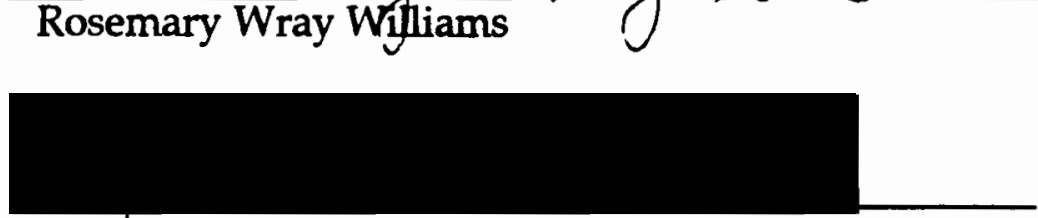

Michael Arcidiacono

A questionnaire based on Gardner's Theory of Multiple Intelligences was developed and administered to forty-five second grade students in three different classrooms. Sections of the fifty-eight item questionnaire dealt with students' preferences for certain classroom activities, methods of learning, and modes of social interaction. Each student's responses were summarized to create an individual profile, indicating preference for linguistic, mathematical, and/or 
spatial activity. In addition, students' preferences for receptive and/or expressive methods of learning, and for working by themselves, with peers, or with adults were profiled.

Of the forty-five students who participated in the study, eight expressed strong preference for linguistic activity, five for mathematical activity, fifteen for spatial activity, and seventeen for a combination of two or three activity types. Seven of the forty-five youngsters indicated preference for such receptive methods of learning as listening, reading, and watching, while thirty-one favored more expressive methods (telling, drawing, and building), and seven expressed preference for various combinations of receptive and expressive methods. Fifteen of the participating students indicated that they most preferred to work alone, sixteen expressed preference for working with peers, three expressed preference for working with adults, and eleven indicated preference for some combination of two or three types of social interaction.

In order to examine connections between expressed preferences and actual classroom performance and behavior, Classroom Preference Questionnaires on each of the participating students were also completed by teachers. Teachers were requested to base their responses about students' probable preferences for classroom activities, learning methods, and social interactions on their own observations and perceptions. Agreement between expressed student preferences and teacher perceptions was found to be highest in the area of learning methods, with twenty-eight instances of high agreement, twelve moderate, and five low. Agreement between teachers and students was less consistent in the areas of classroom activity and social orientation. In general, teachers seemed to 'read' some of their students, particularly those with very definite preferences, more accurately than others. 
Selected student work samples were also examined to establish connections between students' expressed preferences and actual performance. The efforts of children who expressed high preference for linguistic activities and who were also perceived by their teachers to prefer such activities, were found to be characteristically 'chatty'. It appeared that these children were very aware of communicating with others, and used spoken and written words as a vehicle to approach many different learning tasks. The efforts of students who expressed strong mathematical preferences, on the other hand, were more compact. Ideas and solutions tended to be reported briefly; these students' concerns appeared to revolve around the quantitative properties of physical objects (number, size, location, relationship), and numbers or logical chains of reasoning often figured in their responses to classroom tasks. The efforts of students with strong spatial preferences also appeared to reflect concern with the world of physical objects, but these students were particularly attuned to the visual properties of objects, making frequent use of sketches and diagrams in response to spatial, mathematical, and even linguistic tasks. Finally, students who indicated fairly equal preference for all three types of activity seemed to use the favored learning vehicles of each domain in balance.

In summary, there appeared to be fair correspondence between children's expressed preferences and their actual performance in the classroom, as perceived by teachers and evidenced in work samples. Inasmuch as the Classroom Preferences Questionnaire offered information about children's favored learning vehicles (words, numbers, diagrams, and/or objects), approaches to learning (receptive or expressive), and modes of social interaction, it provided a useful lens through which to view and interpret student's work and classroom behavior. 
A CLASSROOM PREFERENCES QUESTIONNAIRE BASED ON THE THEORY OF MULTIPLE

\title{
INTELLIGENCES
}

by

ALLYN SNIDER

A thesis submitted in partial fulfillment of the requirements for the degree of

\author{
MASTER OF SCIENCE \\ in \\ EDUCATION: CURRICULUM AND INSTRUCTION
}

Portland State University

1992 


\section{TO THE OFFICE OF GRADUATE STUDIES:}

The members of the Committee approve the thesis of Allyn Snider presented July 16, 1992.

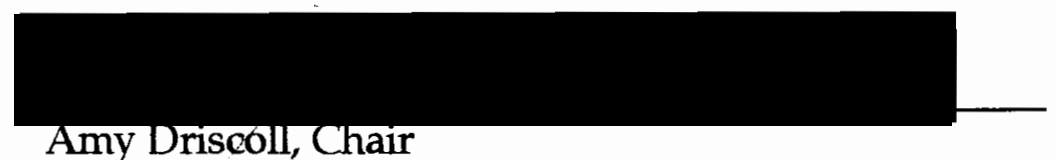

Amy Driscoll, Chair

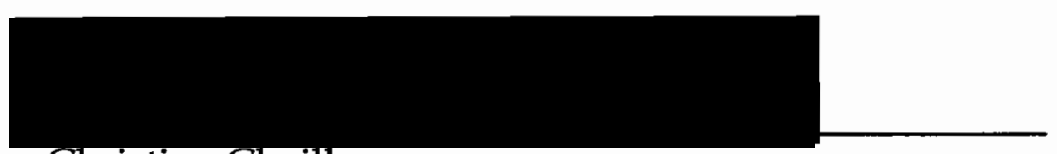

Christine Chaille

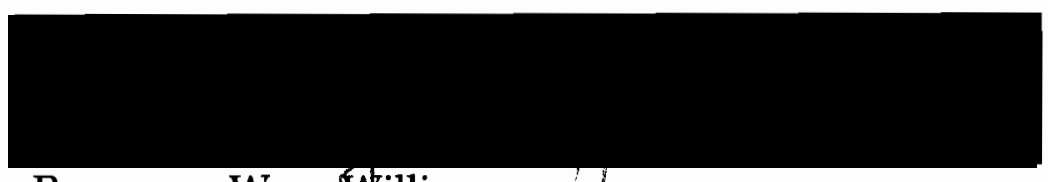

Rosemary Wray Williams

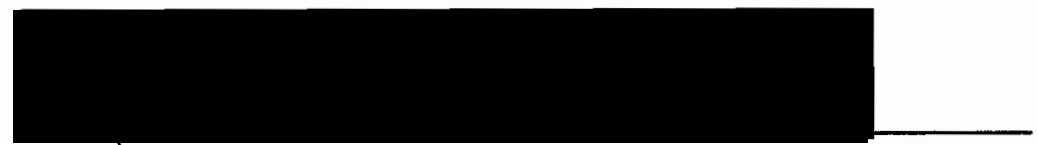

Michael Arcidiacono

\section{APPROVED:}

Robert B. Everhart, Dean, School of Education

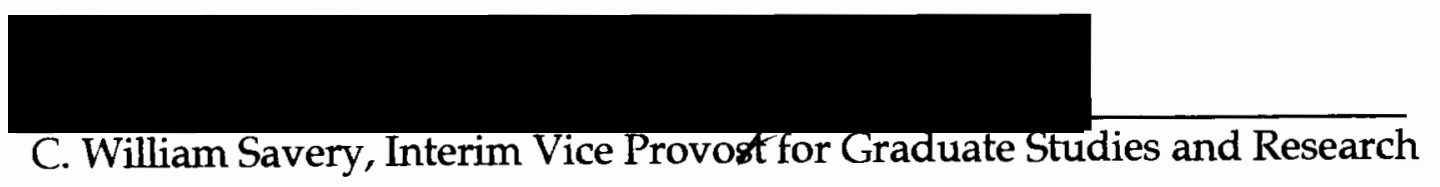




\section{ACKNOWLEDGEMENTS}

I wish to thank Rosemary Wray of the Math Learning Center for her invaluable help in designing and revising the Classroom Preferences Questionnaire. I also wish to thank Lindy Delf, Janet Johnstone, Veronica Parachinni, and their second graders for allowing me to spend so many hours in their classrooms observing and asking questions. Thanks also to my advisor, Amy Driscoll, and my committee members, Christine Chaille, Mike Arcidiacono, and Rosemary Wray for their help and support. Finally, thanks to Vaunie Maier for typing and editing the manuscript. 


\section{TABLE OF CONTENTS}

PAGE

ACKNOWLEDGMENTS..................................................................................... iii

LIST OF TABLES ................................................................................................. vii

LIST OF FIGURES ......................................................................................................... viii

\section{CHAPTER}

New Trends in Assessment .................................................. 1

Initial Explorations.................................................................... 2

Multiple Intelligences in the Classroom? .............................. 4

Evolution of the Classroom Preferences Questionnaire..... 6

II LITERATURE REVIEW .................................................................... 8

The History of Multiple Intelligences ……............................. 8

Gardner's Theory of Multiple Intelligences ......................... 10

Measuring Multiple Intelligences .......................................... 12

Related Research in the Field of Learning Styles................. 14

III DEVELOPING THE CLASSROOM PREFERENCES

QUESTIONNAIRE .................................................................... 17

Statement of Research Questions.......................................... 17

Selecting Areas Classroom Endeavor to Match Multiple Intelligences 
Developing a Questionnaire Format - The Paired Comparison Model 20

Field-Testing the Questionnaire ........................................... 22

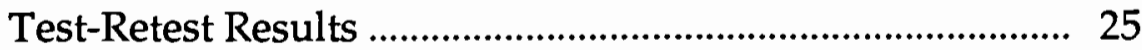

Teacher's Rating of Children's Demonstrated Preferences 28

Research Questions Revisited 31

Classroom Overviews

Administering the Classroom Preferences Questionnaire to Students

Administering the Classroom Preferences Questionnaire to Teachers

Data Analysis Methods - Scoring Students' and Teachers' Responses

Comparing Students' and Teachers' Responses

Investigating the Connection Between Students' Expressed Preferences and Classroom Performance

Student Responses - Preferred Classroom Activities.

Student Responses - Preferred Methods of Learning ..........

Student Responses - Preferred Modes of Social Interaction

Comparison of Students' and Teachers' Responses............. 51

Examining the Work of "Strong Preference" Students ...... 58

Discussion 


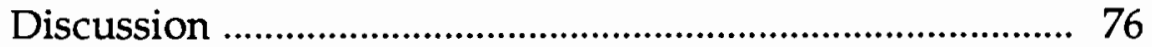

VI CONCLUSIONS AND DISCUSSION ....................................... 78

Using Information Gained from the Classroom

Preferences Questionnaire to Enhance Students'

Self-Knowledge

Using Information Gained from the Classroom

Preferences Questionnaire to Influence Curriculum

Decisions

Using Information Gained from the Classroom

Preferences Questionnaire to Enhance

Assessment

REFERENCES 83

APPENDICES 85

A SUMMARY OF CLASSROOM PREFERENCES QUESTIONNAIRES. 85

B CLASSROOM PREFERENCES QUESTIONNAIRE 88

C PARENT CONSENT FORMS. 95

D SAMPLE RANKING COMPARISON SHEETS 98 


\section{LIST OF TABLES}

\section{TABLE}

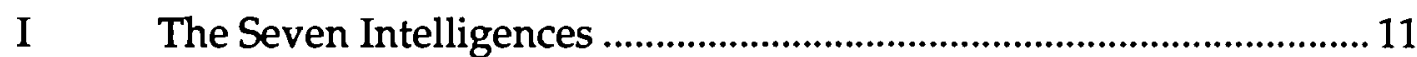

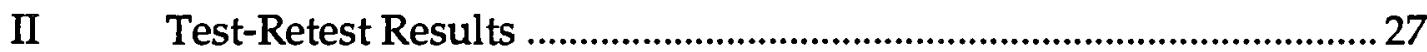

III Mrs. Johnstone's Class: Classroom Activity Preference Profiles 46

IV Ms. Parachinni's Class: Classroom Activity Preference Profiles 47

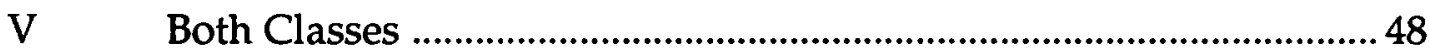

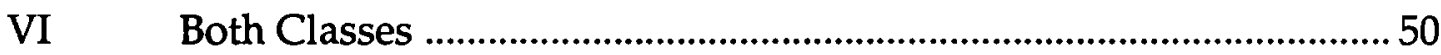

VII Mrs. Johnstone's Class: Comparison of Overall Preference

Profiles as Expressed by Students and Perceived

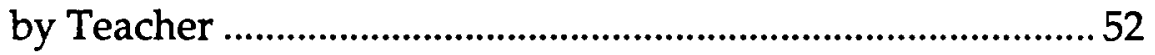

VIII Ms. Parachinni's Class: Comparison of Overall Preference

Profiles as Expressed by Students and Perceived by

the Teacher. .54

IX Summary of Agreement Levels Between Students and Teachers 57 


\section{LIST OF FIGURES}

FIGURE

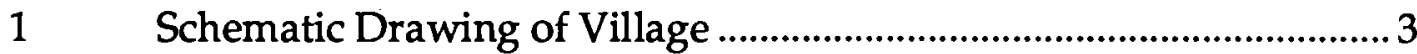

2 Pictorial Drawing of Village .................................................................. 4

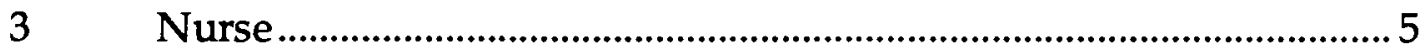

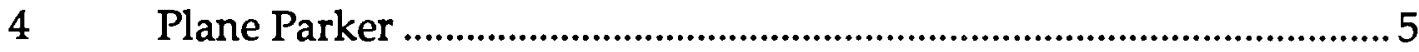

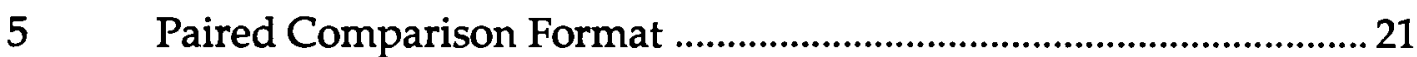

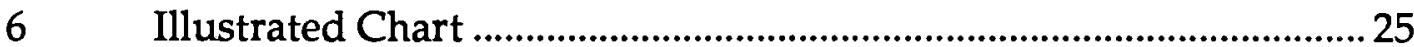

$7 \quad$ Paired Choice Marking System ................................................................ 34

8 Students From Ms. Parachinni's Class ...............................................43

9 Students From Mrs. Johnstone's Class .............................................. 43

10 Anita's Evaluation of The Popcorn Party ..........................................6 60

11 Micah's Evaluation of The Popcorn Party .......................................... 61

12 Martin's Evaluation of The Popcorn Party ......................................... 61

13 April's Evaluation of The Popcorn Party ...............................................6 62

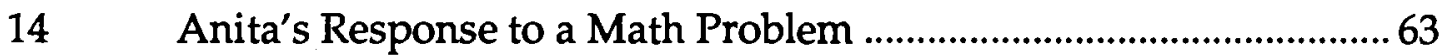

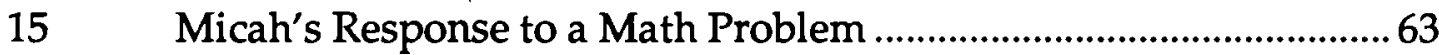

16 Martin's Response to a Math Problem ..................................................6 64

17 Anita's Response to a Math Problem ….................................................65

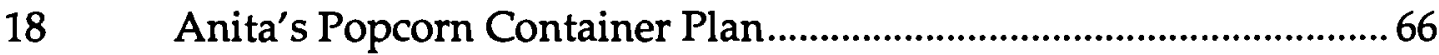

19 Micah's Popcorn Container Plan ...........................................................67 67

$20 \quad$ Martin's Popcorn Container Plan ........................................................67

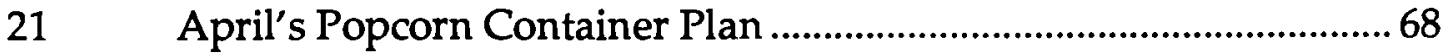


22 A Comparison of Becky's and Spencer's Linguistic Work............... 70

23 Sample of Spencer's Math Work …............................................................ 71

$24 \quad$ Richard's Drawing of the Imagined Village ......................................... 72

25 Vicki's Drawing of the Imagined Village …...................................... 72

26 Vicki's Evaluation of the Gingerbread Village Project .....................73

27 A Comparison of Jay's and Jared's Math Work...............................74

28 Jay's Milk Carton House Plan ................................................................. 75

29 James' Popcorn Container Plan .......................................................... 76

$30 \quad$ Eden's Popcorn Container Plan ....................................................... 76

31 Eden's Response to a Questionnaire About The Popcorn Party ..... 76 


\section{CHAPTER I}

\section{INTRODUCTION}

\section{NEW TRENDS IN ASSESSMENT}

If the 1980's were a decade of reform in curriculum, the 1990's have ushered in a growing recognition that curriculum reform must be accompanied by testing reform. National organizations including the National Council of Teachers of Mathematics (1991), the National Commission on Testing and Public Policy (1990), the National Center for Improving Science Education (1989), and the National Association for the Education of Young Children (1991) are now urging educators to use assessments that align with current views of curriculum and reflect children's learning more accurately than standardized paper and pencil testing. In recent publications, NAEYC and NCTM have called for evaluation procedures that

- are linked closely with on-going classroom instruction and activity

- use a variety of methods to assess children's progress

- are collaborative (i.e., focused on the judgment of all those concerned - student, teacher, and parent)

- examine what children can do rather than what they can't

- help teachers more adequately meet the needs of individual learners.

These reforms in assessment are expected, in turn, to further enhance teaching practices; if evaluation is to be performance-based, children must be given opportunities to develop and display their abilities by engaging in tasks more complex than filling in blanks on a worksheet or bubbles on a test form. But if alternative forms of assessment are viewed by some as key elements in the reform 
movement, their development has sometimes lagged behind the curriculum they support. Such is the case with Math Excursions, a set of integrated units published recently by Heinemann Books (Burk, Snider, and Symonds, 1991).

When Math Excursions 2 was first developed, the intent was to give second graders opportunities to use math as a tool with which to pursue projects or conduct investigations. Mathematics topics such as estimation, number sense, computation, geometry, measurement, statistics, patterning, and problem solving were not meant to be studied systematically or at length, but simply used as they related to such practical problems as building models, planning parties, or making quilts. Of course, different students displayed very different profiles of performance along the dimensions represented by these different skills, which made assessment problematic. Consequently, the topic was not addressed particularly well in the first edition, and became a focus for my thesis.

\section{INITIAL EXPLORATIONS}

The first step in developing some effective assessment strategies for Math Excursions was to determine what could be learned about a group of children by watching them go through one of the Excursions units. When a teacher at a local school said she was planning to do "The Gingerbread Village" with her second graders last December, I saw an opportunity to develop a set of criteria to guide future observations and assessments based on children's actual responses to the tasks and problems posed by the unit. But it didn't take too many days to realize that I was watching social, linguistic, spatial, and kinesthetic behavior as well as, or even instead of, mathematical problem solving at times. I began to feel that mathematical assessments alone would exclude much of the children's work, and that my strategies ought to reflect the integrated nature of the units. 
This was exciting but overwhelming. What to look for? When? The longer I watched, the more apparent it became that each child in this classroom had a distinct set of strengths, as well as some weaker areas. Jay ${ }^{1}$, who couldn't read, write, or compute particularly well, drafted complex plans for his milk carton house and then astonished us by following them exactly. Vicki and Becky took two days longer than anyone else to make their building because neither would compromise with the other. LaTonya, Nick, and Richard could add long strings of numbers in their heads, while Terry, who could barely count on, was able to propose model sizes for buildings based on size comparisons of real buildings. Moreover, it appeared that students approached the same tasks in different ways. When asked to draw their visions of the finished village at the beginning of the unit, some children focused on spatial relationships, creating map-like schematics (see Figure 1), while others produced highly pictorial, story-like drawings, complete with flowers, trees, and people (see Figure 2).

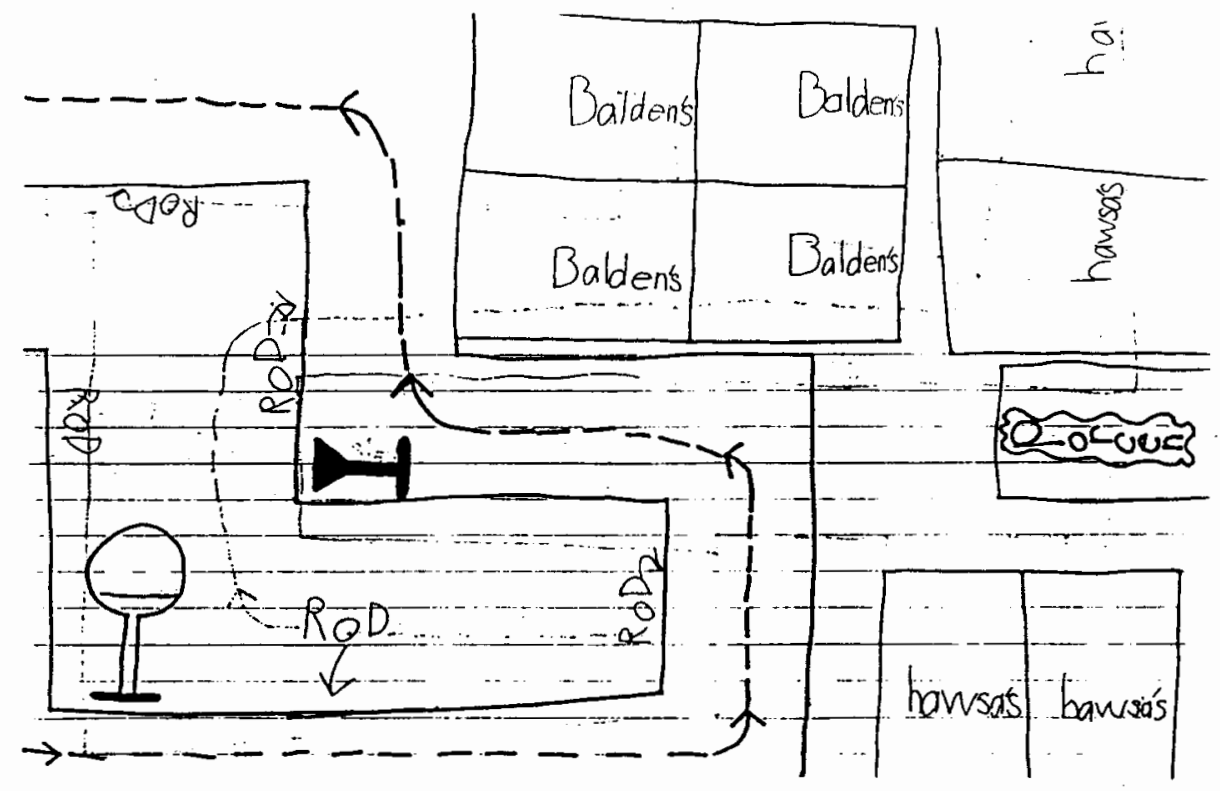

Figure 1. Schematic drawing of village.

1 Student names throughout this document have been changed 


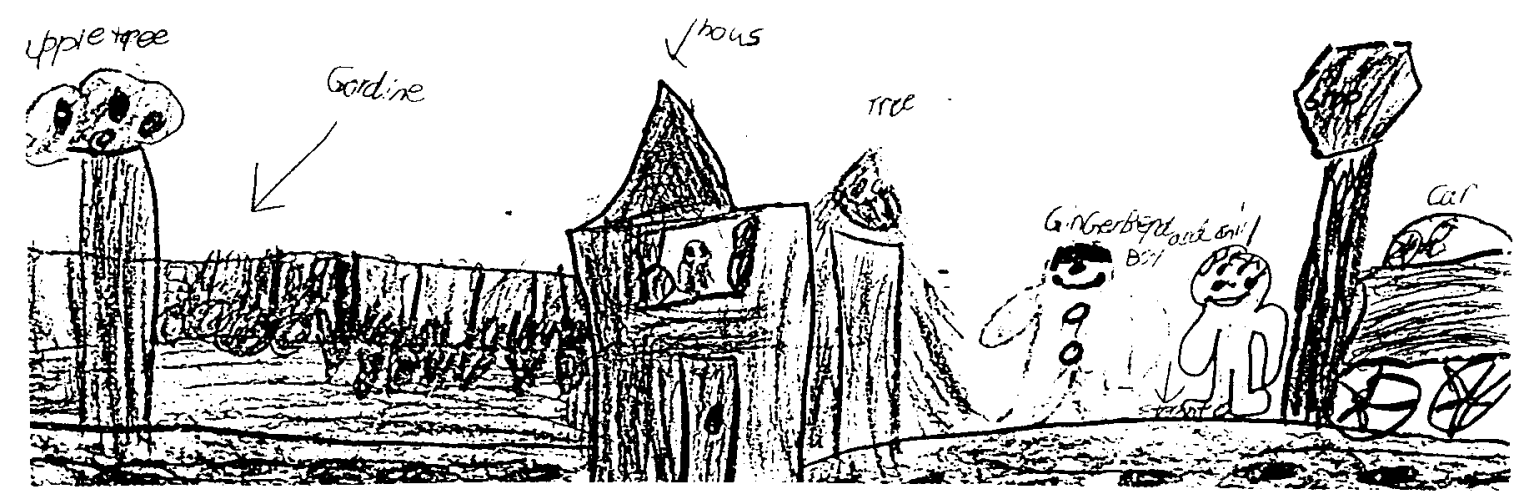

Figure 2. Pictorial drawing of village.

When asked to describe their gingerbread citizens later, some children focused on the social roles and transactions of their workers (see Figure 3), while others responded in a more configurational manner, describing the clothing and other accouterments of their workers (see Figure 4). It seemed that some students favored verbal and written descriptions over visual means of articulation even when engaged in spatial tasks such as drawing and building, while others appeared to flourish in the creation of two- and three-dimensional displays and often had little to say when writing descriptions or reactions. Why was this, and was it coincidental that the verbalizers generally appeared, in their teacher's estimation, to be better students, while some of the more spatially inclined youngsters apparently had a harder time reading, writing, doing computation, and keeping up with school-related tasks?

\section{MULTIPLE INTELLIGENCES IN THE CLASSROOM?}

In searching for a way to understand the diverse behavior of these second graders, I came across an article that explained Howard Gardner's theory of multiple intelligences (Frames of Mind,1983) from the vantage point of classroom practitioners. According to Gardner, the authors explained, humans have at least 


\section{vurs}

My Worker

This is what my worker wears to work:

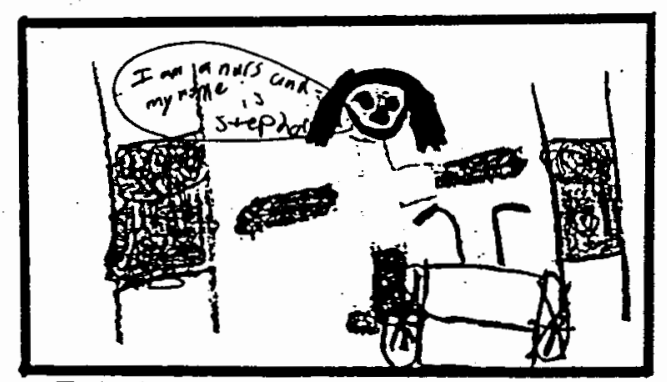

This is what my worker does at his, her. job:

$$
\begin{aligned}
& \text { she heles people, if they call } \\
& \text { her aomic and they say Ineed } \\
& \text { some foed I will oet it for } \\
& \text { thembut twant give it fo them } \\
& \text { a baby freezing in the soow she } \\
& \text { will hulp heretim. }
\end{aligned}
$$

Figure 3. Nurse. (She helps people if they call her name and they say I need some food I will get it for them after dinner. And if they find a baby freezing in the snow she will help her, him .)

$$
\text { Pinyn Parcher }
$$

My Worker

This is what my worker wears to work:

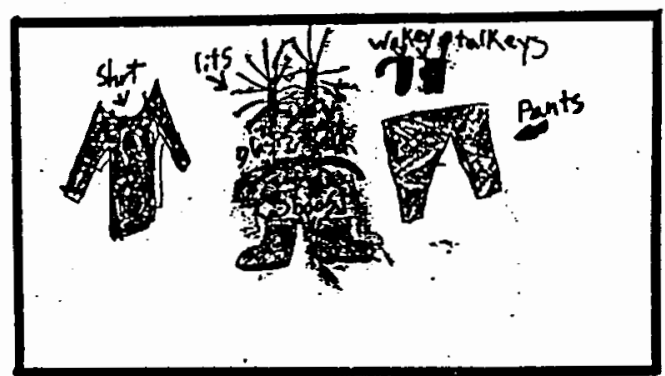

This is what my worker does at his job:

He shows Plans were tor
Parck. the stroff un in. the sckwe
is the stuff he weres,

Figure 4. Plane parker. (He shows planes where to park. The stuff up in the square is the stuff he wears.)

seven distinct intelligences: linguistic, logical-mathematical, spatial, kinesthetic, musical, interpersonal, and intrapersonal. Furthermore, each individual exhibits a distinct profile of strengths and weaknesses with respect to these intelligences. The tendency toward greater strengths in certain types of intelligence over others may make a difference in students' preferred learning styles, interests, and future career choices. By being more aware of students' preferred learning styles, teachers might encourage those "at promise" in a particular intelligence, provide intervention for those "at risk", and "help all students find their niche in learning and in life" (Faggella and Horowitz, 1990). 
The article went on to describe the characteristics of each intelligence, including 'linguistic learners', who like to read, write, and tell stories; 'logical-mathematical learners', who enjoy doing experiments, figuring things out, working with numbers, and exploring patterns and relationships; 'spatial learners', good at drawing, building, designing, and creating things; 'kinesthetic learners', often moving, touching, or talking; and 'interpersonal learners', who may learn best by sharing, comparing, relating and cooperating.

\section{EVOLUTION OF THE CLASSROOM PREFERENCES QUESTIONNAIRE}

These ideas were intriguing, but I wondered how such styles or intelligences could be identified in second grade students. Teachers of very young children are often able to construct rich portraits of students' interests and proclivities over a year's time because their programs provide enriching materials across a broad, diversified range of content areas. By second grade, however, the sand table, woodworking bench, and building blocks are gone. While opportunities to identify linguistic and mathematical learners abound, it's more difficult to spot children who may have spatial, kinesthetic, interpersonal, or intrapersonal strengths. At first I thought the Math Excursions units themselves might provide an opportunity to gauge students' intelligence strengths, but realized that such observations might be difficult to make in the short amount of time - 2 to 4 weeks - allowed for each unit. Yet I saw clear evidence of linguistic, mathematical, spatial, kinesthetic, and interpersonal strengths in children as they worked at the broadbased Excursions tasks.

Then I reasoned that if teachers of younger children made use of data generated during choosing time (e.g., youngsters' social behavior, the frequency with which they visit certain areas, cognitive skills demonstrated while using various 
materials) as a point of entry for assessment, perhaps some sort of questionnaire that allowed second graders to express their preferences for certain classroom activities, ways of working, and levels of social interaction could be designed. Students' expressed preferences might, in turn, offer teachers a way to focus their observations and inquiries during Excursions units or other classroom work. If, for instance, a child expressed strong preference for spatial activities and ways of working, perhaps supporting evidence could be found in his or her work; evidence that might allow the student, teacher, and parents to acknowledge and value a strength that often goes unnoticed. If a child expressed strong preference for working alone, perhaps observations could be made during partner or smallgroup work to determine why, and to provide intervention if necessary.

Information from such a questionnaire might also allow teachers and students to acknowledge the fact that people in any group have different preferences; that some like to work in small groups while others prefer to work alone; that some approach learning tasks by listening, watching, reading, or planning, while others prefer more active modes of engagement. With these ideas in mind, I abandoned the task of developing assessment strategies for Math Excursions per se, and turned my attention to developing a questionnaire that would allow teachers to focus their observations and inquiries by profiling children's preferences and possibly their actual intelligence strengths. 


\section{CHAPTER II}

\section{LITERATURE REVIEW}

\section{THE HISTORY OF MULTIPLE INTELLIGENCES}

The idea that intelligence is not a single, general factor but a set of abilities extends back at least two hundred years to Franz Gall. Gall investigated the bumps on individuals' heads, searching for the hills and valleys in each specific region that he believed would reveal strengths, weaknesses, and idiosyncrasies. For him, the measure of intelligence resided in the pattern of cranial bumps found on a person's head.

During the first half of the twentieth century, the model of intelligence as something to be mapped dominated theory and research. The psychologist studying intelligence was both an explorer and a cartographer, working by touch no longer but with the statistical tool of factor analysis - "a means of separating intelligence into a number of hypothetical factors or abilities that are believed to form the basis of individual differences in test performance" (Sternberg, 1988). The major debate among these theorists - including Spearman, Thurstone, Guilford, Cattell, and Vernon - centered on the issue of the "true" factorial structure, or map, of intelligence.

Charles Spearman believed that intelligence could be understood in terms of a single general factor, " $\mathrm{g}$ ", as well as a set of less influential factors, each of which was involved in performance on a single type of mental ability. Louis Thurstone, on the other hand, believed that the core of intelligence resided not in 
one single factor, but seven, including verbal comprehension, verbal fluency, inductive reasoning, spatial visualization, number, memory, and perceptual speed. J. P. Guilford proposed as many as 150 factors in his structure-of-intellect model, while Raymond Cattell held to a much more modest figure of two major subfactors, fluid ability (the understanding of abstract relationships) and crystallized ability (the accumulation of facts, ideas, and strategies). A similar theory was proposed by Philip Vernon, who made a general division between practical-mechanical and verbal-educational abilities.

In the latter half of this century, many psychologists, including Earl Hunt, Herbert Simon, and Robert Sternberg, moved towards a computational model, seeking to understand the information processing people do when they think intelligently. Still others, including David Feldman, David Olson, Gavriel Salomon, and Howard Gardner, took a "symbol systems" approach, seeking to uncover the fine structure of development within and between the symbol systems of language and literacy, mathematics, visual design, music, and movement. As a result of his own studies of the development and breakdown of cognitive and symbol-using capacities, Gardner came to believe that "separate psychological processes appear to be involved in dealing with linguistic, numerical, pictorial, gestural, and other kinds of symbolic design" (Gardner and Wolf, 1983). On a more practical level, he became increasingly disturbed by the fact that IQ tests measured only linguistic and logical-mathematical capacities. This narrow definition of intelligence, he felt, failed to explain such areas of human endeavor as chess and other games of strategy, musical and athletic performance, artistic or mechanical design, and navigation. Furthermore, it encouraged educators to bypass children who had strengths in areas other than language or mathematics. 


\section{GARDNER'S THEORY OF MULTIPLE INTELLIGENCES}

As a result of these and other factors, Gardner developed a conceptualization of the human intellect that took into account a wide variety of cognitive capacities, and entailed many kinds of symbol systems. In his theory of multiple intelligences, he defined intelligence as the "capacity to solve problems or to fashion products that are valued in one or more cultural settings" (Gardner, 1983). To arrive at his list of intelligences, Gardner and his colleagues examined the literature in a number of areas, including the development of cognitive capacities in normal individuals; the breakdown of cognitive capacities under various kinds of organic pathology; the existence of abilities in such "special populations" as prodigies, autistic individuals, and learning disabled children; forms of intellect valued in different cultures; and two forms of psychological evidence - the results of factor-analytic studies of human cognitive capacities and the outcome of studies of transfer and generalization. Gardner's provisional list includes seven intelligences, each with its own component processes and end states (see Table I, below, from Gardner and Hatch, 1989).

According to Gardner, each of us possesses all seven intelligences to some degree, but we also exhibit distinct profiles of intelligence, or areas of relative strength or weakness. Thus, one individual may be particularly strong in linguistic and interpersonal intelligence, while another exhibits a great deal of logicalmathematical and spatial strength. Our various intellectual competencies can serve both as means and message in an educational setting. That is, the abilities entailed in an intelligence can be used as a means of acquiring information, even as the material to be mastered may itself fall within the domain of a specific intelligence. If someone learns algebra, for instance, the knowledge to be gained is 
TABLE I

\section{THE SEVEN INTELLIGENCES}

Intelligence

Logical-mathematical

Linguistic

Musical

Spatial

Bodily-kinesthetic

Interpersonal

Intrapersonal
End-States

Scientist

Mathematician

Poet

Journalist

Composer

Violinist

Navigator

Sculptor

Dancer

Athlete

Therapist

Salesman

Person with detailed, accurate self-knowledge

\section{Core Components}

Sensitivity to, and capacity to discern, logical or numerical patterns; ability to handle long chains of reasoning.

Sensitivity to the sounds, rhythms, and meanings of words; sensitivity to the different functions of language.
Abilities to produce and ap- preciate rhythm, pitch, and timbre; appreciation of the forms of musical expressive- ness.

Capacities to perceive the visual-spatial world accurately and to perform transformations on one's initial perceptions.

Abilities to control one's body movements and to handle objects skillfully.

Capacities to discern and respond appropriately to the moods, temperaments, motivations, and desires of other people.

Access to one's own feelings and the ability to discriminate among them and draw upon them to guide behavior; knowledge of one's own strengths, weaknesses, desires, and intelligences.

logical-mathematical, but depending on the individual's particular intelligence strengths, the information may be gained largely through the exploitation of linguistic codes, mathematical chains of reasoning, or spatial demonstrations. 


\section{MEASURING MULTIPLE INTELLIGENCES}

In order to take advantage of students' multiple intelligences, there must be some way to identify their strengths and weaknesses reliably, and this, in fact, has been the thrust of Gardner's work for the last decade. In each of three major undertakings, Project Spectrum, Arts PROPEL, and the Key School, Gardner and his colleagues have worked to develop assessments for the various intelligences, seeking to demonstrate that they are relatively independent of one another and that individuals have distinct profiles of intelligence. Because traditional paperand-pencil intelligence tests have stressed linguistic and logical skills almost exclusively, the researchers have had to take a fresh approach, using materials and methods that deal more directly with the symbol systems that apply to each intelligence. For example, the spatial intelligence of children can be assessed by asking them to complete a set of visual tasks in a test booklet, but Gardner and his associates prefer to have students actually take apart and reassemble a meat grinder.

The activity requires them to "puzzle out" the structure of the object and then to discern or remember the spatial information that will allow reassembly of the pieces. Although linguistically inclined children may produce a running report about the actions they are taking, little verbal skill is necessary (or helpful) for successful performance on such a task. (Gardner and Hatch, 1989)

In developing assessments that are "intelligence fair", based on familiar activities, and set in familiar contexts, Gardner and his colleagues have come to believe that information can and should be drawn from classroom curriculum, as long as such curriculum is rich and evocative, filled with opportunities for students to exercise all seven types of intelligence. Thus, the Project Spectrum researchers have developed a set of 15 different activities for preschoolers, featuring miniature replicas and props, household objects, science materials, math 
games, and creative movement, each of which taps a particular intelligence or set of intelligences. Provision of this variety of "high-affordance" materials allows children to gain experiences that engage their several intelligences, even as teachers have the chance to observe and assess children's strengths, interests, and proclivities (Wexler-Sherman, Gardner, and Feldman, 1988). At the elementary level, Patricia Bolanos and her colleagues have used MI theory to design an entire public school in Indianapolis. Through a variety of special classes, all children in the Key School are given opportunities to discover their areas of strength and to develop the full range of intelligences. In addition, each child executes a number of projects based on schoolwide themes, which are videotaped and subsequently analyzed (Blythe and Gardner, 1990). At the junior and senior high school level, Arts PROPEL seeks to assess growth and learning in such areas as music, creative writing, and visual arts, through a series of "domain projects," that serve the goals of both curriculum and assessment (Walters and Gardner, 1990).

Although Gardner and his fellow investigators have yet to prove conclusively that there are exactly seven intelligences, all of which operate with relative independence, their results have been reasonably consistent with the claims of MI theory. Furthermore, they feel that their programs with both older and younger children confirm that consideration of a broader range of talents brings to the fore individuals who might otherwise have been considered unexceptional or even at risk for school failure. In the words of Gardner, who's always quick to acknowledge that multiple intelligences is a construct rather than scientific fact, "The goal of detecting distinctive human strengths, and using them as a basis for engagement and learning, may prove to be worthwhile, irrespective of the scientific fate of the theory" (Gardner and Hatch, 1989). 


\section{RELATED RESEARCH IN THE FIELD OF LEARNING STYLES}

It must be noted that research bearing much resemblance to Gardner's has been taking place in the related field of learning styles since the early 1970's. In standard theories of intelligence, including Gardner's (1983) and Sternberg's (1985), the emphasis is on measuring how much of each ability the individual has. In contrast, the learning style theorists are interested in how an individual's intelligence is directed or exploited. Robert Sternberg, a noted psychological researcher with his own theory of intelligence, heralds the advent of learning styles with the words, "Intellectual styles represent an important link between intelligence and personality because they probably represent a way in which personality is manifested in intelligent thought and action. Measuring styles is a first step toward understanding people's preferences for ways of using their intelligence. Ultimately we hope to be able to teach students to use various styles flexibly in order to optimize the extent to which they can apply their intelligence, both in and out of school" (Sternberg, 1990). If Sternberg's words seem reminiscent of Gardner's, this may reflect the fact that Gardner regards an individual's intelligence strength as his or her preferred approach to learning as well as a determinant of the subject material at which he or she may excel. In early studies of very young children, Wolf and Gardner identified "patterners' or "visualizers", who displayed strong interest and skill in configurational uses of materials - the making of patterns, structures, and orders; and "dramatizers' or verbalizers', who showed tremendous interest in what others did, how they thought and felt, and how they could be contacted and affected (Wolf and Gardner, 1975).

Furthermore, the researchers noted that even very young children tended to acquire the basics of symbolic competence using their own particular strengths. 
...our findings held out the possibility that children termed dramatists might exploit their sensitivity to narrational forms not only as a route to acquiring event-structure skills but also as a means for acquiring mapping skills. Conversely, it suggested that while patterners developed the simplest event structures in synchrony with dramatists, they employed their configurational abilities to construct full-blown event structures. (Wolf and Gardner, 1975)

Gardner (1983), Sternberg (1990), and such learning style theorists as David Kolb (1984), Bernice McCarthy (1990), Rita Dunn (1978), and James Keefe (1990) all propose that educators tailor their instruction to the abilities and needs of the particular individuals involved. The cost of attempting to treat all individuals the same, these researchers feel, or of trying to teach individuals in ways uncongenial to their preferred modes of learning, may be great. On the other hand, teaching matched to student style promotes achievement, and increased achievement wins new converts, especially among "at-risk" students, who may be discriminated against in classrooms because their preferences and styles often don't match prevailing practices (Guild, 1990).

Although each of these researchers has his or her own definition of what constitutes learning style, all, with the exception of Gardner, use self-report instruments to measure individuals' learning styles, as well as teacher observation of student behavior and analysis of student performance. Sternberg (1990) asks college students to rate a collection of statements on a 1-to-9 scale, while McCarthy and Kolb use an inventory in which adults choose words that best describe their learning preferences (Kolb, 1984). Dunn and Dunn have developed an instrument for students above second grade in which children mark each of one hundred statements about environmental, emotional, sociological, and physical preferences true or false (Dunn and Dunn, 1978). A modified version of Dunn and Dunn's self report form has also been developed for first and second graders. The Picture Learning Style Inventory (Perrin, 1980) consists of thirteen individual pic- 
ture booklets, each of which illustrates a different element of learning style. The inventory is administered verbally to small groups of children in several sessions. In short, although Gardner's attempts to assess intelligence strengths/styles has largely revolved around observation of children at selected tasks in rich environments, there are many precedents for attempting to gauge students' styles through self-report instruments as well. 


\section{CHAPTER III}

\section{DEVELOPING THE CLASSROOM PREFERENCES QUESTIONNAIRE}

\section{STATEMENT OF RESEARCH QUESTIONS}

Given the available precedents and the fact that I was interested in developing some way to focus classroom observation and inquiry, the research questions I chose to investigate were quite basic:

1. Could certain classroom activities, approaches to learning tasks, and modes of interacting with others be identified that would give insight into children's intelligence profiles as outlined by Gardner?

2. Could a simple instrument be developed which would provide insight into second graders' preferences in these key areas?

3. Would children's stated preferences match classroom performance and behavior as indicated by a) teacher perception and/or, b) actual work samples?

\section{SELECTING AREAS OF CLASSROOM ENDEAVOR TO MATCH MULTIPLE INTELLIGENCES}

Working from the core components of Gardner's seven intelligences (see Table I, page 9) along with Faggella's and Horowitz's interpretations (1990), it was possible to identify certain activity preferences and approaches to learning that might characterize children with linguistic, logical-mathematical, spatial, kinesthetic, interpersonal, and intrapersonal strengths. Because music was outside the scope of Math Excursions, I made a decision early on to leave it out. Students with linguistic strengths, it seemed, might be inclined to choose reading, writing, and telling stories over most other classroom activities. Words 
would probably be their chosen mode of expression. Logical-mathematical learners would be drawn to math and problem-solving activities, choosing numbers or reasoned chains of logic as preferred modes of expression and inquiry. The child with spatial strengths would most likely choose art and design activities, preferring pictures and diagrams as a means of expression and investigation. A kinesthetic learner would most likely be in motion much of the time, preferring such active modes of learning as building, manipulating objects, taking things apart, and using them, as opposed to watching or reading about them. I wasn't sure I could identify interpersonal and intrapersonal learners without extensive observation and inquiry, but it seemed possible for children to indicate preferences for working by themselves, with peers, or with adults in the context of a simple questionnaire.

I approached the task of selecting specific classroom activities and learning methods by trial and error, working through several drafts with the help of Rosemary Wray of the Math Learning Center and students in a local second grade classroom. The final list of activities, approaches to learning, and social preferences is shown below:

Preferred Classroom Activities (Linguistic, Mathematical, or Spatial)

Preferred Subject

- reading (linguistic)

- writing (linguistic)

- math (mathematical)

- art (spatial)

-science (spatial)

Preferred Tool

- words (linguistic)

- numbers (mathematical)

- diagrams (spatial)

- objects (spatial/kinesthetic) 
Preferred Language Activity

- write a story (linguistic)

- write a math story problem (mathematical)

- write a set of instructions (spatial)

Preferred Type of Math Problem

- word problem (linguistic)

- computational problem (mathematical)

- spatial problem (spatial)

Preferred Art Activity

- draw a story illustration (linguistic)

- draw a pattern (mathematical)

- draw a map (spatial)

Preferred Method of Learning,Working, or Investigating Problems (Methods go from more receptive to more expressive and become increasingly kinesthetic as one progresses through each set of four.)

In Language Arts

- listening to a story (receptive)

- reading a story (receptive)

- telling a story (expressive)

- writing a story (expressive)

In Figuring out a Math Problem

- figuring it out in your head (receptive)

- figuring it out on paper (expressive)

- drawing a sketch or diagram (expressive)

- using manipulatives (expressive/kinesthetic)

In Learning About How Something Works

- watching it (receptive)

- reading about it (receptive)

- taking it apart (expressive/kinesthetic)

- using it (expressive/kinesthetic)

In Working on an Invention

- planning it in your head (receptive)

- writing about it (expressive)

- drawing it (expressive)

- building it (expressive/kinesthetic)

Preferred Social Orientation (Self, peer, or adult-oriented)

Working in Class

- alone (self-oriented)

- with a partner (peer-oriented) 
- with a small group (peer-oriented)

- with the entire class (adult-oriented)

Deciding What to Draw or Write

-your own idea (self-oriented)

- an idea you made up with other kids in the class (peer-oriented)

-your teacher's idea (adult-oriented)

\section{DEVELOPING A QUESTIONNAIRE FORMAT - THE PAIRED COMPARISON MODEL}

Had I wanted students to indicate only one preference under each heading, the questionnaire would have been easy to compose. What I was after, however, was a rank ordering of items in each category. Under "Preferred Subject", for instance, I was interested to know that math was a student's top favorite, but felt there was something more to be gained by knowing that she ranked math first, art second, science third, writing fourth, and reading fifth. Given the fact that rank ordering three or more items is difficult even for adults, I decided to use a paired comparison format, in which students would never be asked to choose between more than two items, but choices could be tallied to determine ranking. The paired comparison model is considered to have several advantages over other approaches to gauging people's preferences, including the fact that "the data production task imposed on subjects is both simple and fast, allowing the scaling of many stimuli and the easy collection of large data sets" (Bradford and Schriesheim, 1990).

To set up a list of choices in such a format, each choice is simply paired with every other choice in the set. That is, given choices $a, b, c$, and $d, a$ is paired with $b$, $c$, and $d ; b$ is paired with $c$ and $d$, and $c$ is paired with $d$ (see Figure 5). 


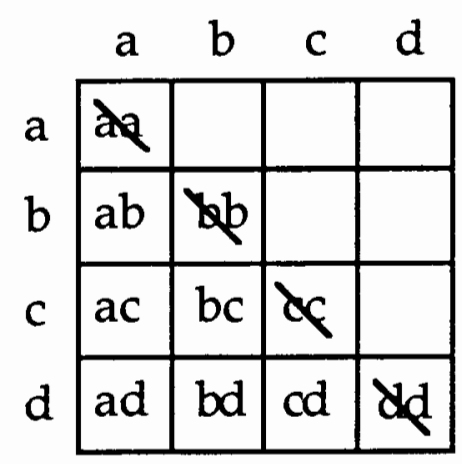

Figure 5. Paired comparison format.

Thus, the list of four items under "Preferred Method of Figuring Out a Math

Problem" generates six questions:

Would you prefer to work on a math problem by:

-figuring it out in your head or figuring it out on paper?

-drawing a sketch or diagram or using manipulatives?

- figuring it out on paper or drawing a sketch or diagram?

- using manipulatives or figuring it out in your head?

-drawing a sketch or diagram or figuring it out in your head?

- using manipulatives or figuring it out on paper?

Rank ordering of a student's preferences is accomplished by tallying the number of times each item is selected (see example below).

Would you prefer to learn about how something works by:

- watching it or reading about it?

- taking it apart or using it?

- reading about it or taking it apart?

- watching it or using it?

- taking it apart or watching it?

-reading about it or using it?

\begin{tabular}{|l|l|l|}
\hline $\begin{array}{l}\text { Preferred way to learn about } \\
\text { how something works }\end{array}$ & Number of times selected & Rank order \\
\hline watching it & 1 & 3 \\
\hline reading about it & 2 & 2 \\
\hline taking it apart & 0 & 4 \\
\hline using it & 3 & 1 \\
\hline
\end{tabular}




\section{FIELD-TESTING THE QUESTIONNAIRE}

As mentioned previously, the questionnaire went through three drafts, each of which was field-tested with the help of students in Lindy Delf's second grade class at Irvington School. The first draft consisted of 36 paired choice questions, six in each of six categories, including preferred learning tool (words, objects, numbers, pictures), preferred language activity (read, write, tell, listen to stories), preferred method of figuring out a math problem (head, paper \& pencil, unifix cubes, calculator), preferred spatial activity (draw, invent, watch, take apart), preferred work style (alone, partner, small group, whole group), and preferred problem solving activity (make plans, look for patterns, sort things, think of different ways). The first eight students to arrive in Lindy's room on Monday, April $20^{2}$ were selected to fill out the original questionnaire. The nine of us moved into a small workroom nearby and I took about eleven minutes to explain the instrument (what it was for and how to mark the paired choice questions), and to conduct a brief reading and discussion of one or two examples from each page. It took thirteen minutes for all the students to complete the questionnaire, although some finished more quickly. On the whole, they seemed enthusiastic, and were able to operate without much help from me. Several had trouble reading the words "unifix", "calculator", and "partner", and a number of them had questions or comments as they worked, including:

- Do you circle the things on each line?

- It asks the same question over!

2 This group, as it turned out, was hardly a random sample. When I asked Lindy to give me an informal estimate of their reading levels later, she reported that four were high readers, two were high-average, and two were average. Many of her lower readers were in the second field-test group, however. 
- What does this mean - "Watch things happen?"

- I like writing my own stories.

- I don't know which to choose (invent things or take things apart - I like to invent things and then take them apart!)

- Does this number (2.6) tell what page you're on? Then I'm on page 26! (2.6 actually meant page 6 in the second questionnaire booklet, but I didn't bother to explain that to the student.)

- And I'm on page 66!

- This doesn't make sense because when you read stories you listen to them.

The second draft of the questionnaire, which I field-tested with the same eight children nearly doubled in length. It consisted of 61 questions, ten under the category of preferred subject (reading, writing, math, art, science), three under the category of preferred type of math problem (word, computational, spatial), and six in each of eight other categories, some of which were carried over from the first questionnaire, and some of which were new. The changes reflected an effort on my part to learn more about children's intelligence strengths by looking at their preferred approaches to learning. I figured that a linguistic learner might be inclined to find out about how something worked by reading about it, while a spatial child might choose to take it apart and a kinesthetic child might simply use it. I couldn't figure out what sort of behavior would characterize a mathematical thinker, however, and in the final draft, I finally organized my categories under three major sub-headings - Preferred Activity, Preferred Method of Learning, and Preferred Social Orientation (see Appendix A). The categories and questions under the first heading were designed to identify linguistic, spatial, or mathematical preferences, while those under the second were designed to examine children's preferences for working receptively (in-head, tending to absorb rather 
than produce), or expressively (product-oriented). Choices at the expressive end of each category were also quite kinesthetic (building, taking apart, using manipulatives, favoring the use of objects over sketches, numbers, or words). The categories and questions under the third heading were organized to look at children's social preferences - self-oriented (possibly intrapersonal), peer-oriented, or adult-oriented (possibly interpersonal).

By the third draft, which now consisted of 58 items (see Appendix B), my presentation of the questionnaire was much more extensive. I had been unable to eliminate some of the more difficult words ("diagrams", "instructions", "illustration', "manipulatives', 'building'), and felt that some of the children in the second field-test group, which included many of the lower readers in Lindy's class, needed a chance to see the words in print and to establish some common understandings by talking about all the categories and choices before completing the instrument. Consequently, I drew up illustrated charts for each category (see Figure 6), which we read through together and discussed beforehand. Even with a more thorough presentation, however, the time required for all phases - explanation, discussion, and completion - was only thirty minutes.

Children's responses to the questionnaire continued to be quite positive throughout. They seemed intrigued with the idea that someone was asking them about their preferences in school, and even in the second group, there were few reading problems, although one child needed to have the questionnaire read to him in its entirety. By the time I'd tested the third draft, I felt the instrument was sufficiently refined to bear retest with the same group of children. I was also interested to have Lindy complete a questionnaire on each of the eight children in the second group, based on her observations of them over the year. Would her 


\section{Would you rather draw}

\section{a story illustration}

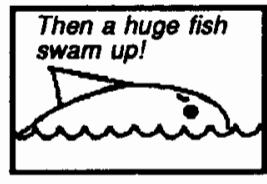

a map

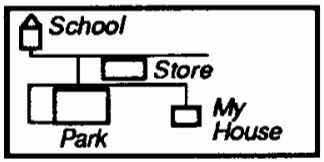

a pattern

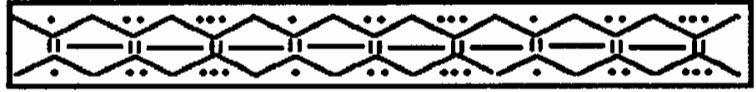

Figure 6. Illustrated chart.

perceptions of these children match their expressed preferences for activities, ways of learning, and social interaction?

\section{TEST-RETEST RESULTS}

In order to look at test-retest reliability, I had the second group of eight students complete the third-draft questionnaire again a week later. I computed the differences in Week One and Week Two scores in three different ways. The first involved computing the difference in the number of times each item was chosen from a pair. For example, a child may have chosen diagrams as a preferred tool three times on the first questionnaire and only twice the second time around. There were 58 response opportunities on the questionnaire, so tally mark difference percentages were computed as $x / 58$, or the number of different responses 
from one week to the next divided by the total number of possible responses.

I also computed the differences between preference ratings for language activities, math activities, spatial activities, expressive or receptive methods of learning, and social orientation (self, peer, or adult) from one week to the next. If a child rated three language activities as first choice and two language activities second choice the first week, her overall language total for that week was $(3 \times 2)+2=8$ preference points (first-choice ratings were double weighted). Thus, a student may have accumulated 8 preference points for language the first week, and only 6 preference points for language the second week, depending on how she ranked various activities each time. In general, these percentages of difference were lower than the percentages calculated on the basis of tally mark placement because of the multi-layered nature of the questionnaire, the fact that children had several opportunities to indicate preferences under each major subheading.

The final method I used to examine test-retest reliability was to contrast children's overall profiles from one week to the next; their top-ranking choices in terms of activity, method of learning, and social orientation. The results of my computations are summarized in Table II. Average test-retest reliability was highest when Week One and Week Two responses were examined for changes in overall preference profile. When the differences in preference rating points were analyzed, average test-retest reliability dropped to $76 \%$, and when differences in actual tally mark placement, which may be the least qualitatively significant measure of the three, were computed, 
TABLE II

TEST-RETEST RESULTS

\begin{tabular}{|l|l|l|l|}
\hline Child Number & $\begin{array}{l}\text { \% Difference in } \\
\text { Tally Point } \\
\text { Assignments }\end{array}$ & $\begin{array}{l}\text { \% Difference in } \\
\text { Preference Rating } \\
\text { Points }\end{array}$ & $\begin{array}{l}\text { Change in Overall } \\
\text { Preference Profile }\end{array}$ \\
\hline 9 & $43 \%$ & $18 \%$ & no change \\
\hline 10 & $29 \%$ & $18 \%$ & no change \\
\hline 11 & $28 \%$ & $13 \%$ & no change \\
\hline 12 & $55 \%$ & $30 \%$ & $\begin{array}{l}\text { change in pre- } \\
\text { ferred learning } \\
\text { method }\end{array}$ \\
\hline 13 & $17 \%$ & $9 \%$ & $\begin{array}{l}\text { slight change in } \\
\text { social orientation } \\
\text { preference }\end{array}$ \\
\hline 14 & $41 \%$ & $41 \%$ & $\begin{array}{l}\text { change in pre- } \\
\text { ferred learning } \\
\text { method }\end{array}$ \\
\hline 15 & & $47 \%$ & $\begin{array}{l}\text { change in pre- } \\
\text { ferred learning } \\
\text { method and social } \\
\text { orientation }\end{array}$ \\
\hline 16 & $41 \%$ & & no change \\
\hline $\begin{array}{l}\text { Average } \\
\text { Differences }\end{array}$ & $33.75 \%$ & $16 \%$ & $19 \%$ \\
\hline $\begin{array}{l}\text { Average Test- } \\
\text { Retest Reliability }\end{array}$ & $66.25 \%$ & $24 \%$ & $81 \%$ \\
\hline
\end{tabular}

test-retest reliability dropped to $66.25 \% \%^{3}$. I was most pleased to see that children's overall profiles did not vary tremendously from one week to the next. Children who indicated strong preferences for spatial activities, expressive methods of learning, and peer-oriented work the first week, for instance, expressed fairly similar preferences the following week.

${ }^{3}$ According to Assessment in Early Childhood Education: A Consumer's Guide (Langhorst, 1989), which designates reliability rating of .70- or great " fair", and total $r$ greater than .80 "good", the reliability ratings obtained for The Classroom Preferences Questionnaire are fairly reasonable. 


\section{TEACHER'S RATING OF CHILDREN'S DEMONSTRATED PREFERENCES}

Once test-retest reliability had been established, I was interested to see how children's expressed preferences for certain classroom activities, methods of learning, and social orientation compared with their demonstrated preferences, as observed by their teacher. My initial inclination was to have Lindy characterize each child as primarily linguistic, mathematical, spatial, or kinesthetic in choice of activities; expressive or receptive in approach to learning; and self, peer, or adult-oriented in class work, by marking global descriptions similar to those developed by Faggella and Horowitz (1990). (See sample below.)

When Lindy attempted to select the global ratings that fit each of the eight children best, she had several problems. For one thing, there was too much information lumped together under each description. She felt one child, for instance, needed pictures to understand new information, but said he didn't do well with maps and charts. Several other children had wonderful gross motor skills, but didn't do well at craft or drawing activities at all. She wondered, also, about the students who loved to read but hated to write, or vice versa. In addition, she found that several descriptions fit some children, while none of the descriptions really characterized others. In the end, I asked her to fill out the same 58-item, paired choice questionnaires as the children. This took her about 45 minutes, and while tedious, allowed her to profile the youngsters more specifically.

In comparing Lindy's perceptions to the self-expressed preferences of this particular group of eight students, I found that she tended to underestimate their predilection for spatial activities, but like the children themselves, identified most as expressive learners, who preferred building, drawing, using sketches or diagrams, taking things apart, and using them. In general, she saw these students as 
Child's Name

Teacher

Date

Preferred Types of Classroom Activity

Please read the descriptions below and choose the one that seems to fit this student most closely. If more than one description seems to apply, rate the top two, marking the one that seems most applicable with a 1, and the one seems second most applicable with a 2.

Loves to read books, write, and tell stories. Has a good memory for names, places, dates, and trivial information. Favorite activities may include storytelling, oral reading, creative writing, audio-taping, written and oral direction games, and joke telling. This child may excel in social studies activities involving dates and places, and will enjoy writing stories and reports.

Enjoys math. Has strong problem-solving and reasoning skills. Asks questions in a logical manner. Favorite activities may include experimenting, exploring, categorizing, classifying, working with numbers, questioning. This child may enjoy breaking codes, solving mysteries, and writing word problems or coded riddles for other children to solve.

Needs a mental or physical picture to best understand new information. Does well with maps, charts, and diagrams. Likes mazes and puzzles. Has a good imagination: can design, draw, and create things. Daydreams. This child is comfortable with organizing visual information, and can conjure up vivid mental pictures of stories.

Is good at physical activities. Has a tendency to move around, touch things, and gesture. Shines in physical skills, both fine and large motor. This child likes craft activities and drawing and can express him- or herself through dance, drama, and movement.

being more peer-oriented than they saw themselves. Five out of the eight rated working alone as their top preference, but in Lindy's estimation, all eight were most likely to prefer working with a partner. I found the differences between teacher and student perceptions provocative and worthy of further consideration; a means, perhaps, of conducting future inquiry and observation. Why was it that so many children in this group expressed higher preference for spatial activities than the teacher had apparently observed in their classroom behavior? Was it the fact that preference doesn't always equal proficiency, so that Lindy might not have judged children with poor drawing skills to be interested in using diagrams or sketches? Could it have been that children weren't given enough opportunity 
to show their preferences and abilities in the realm of spatial activity? Why did Lindy see this group as children who liked to work together when so many of them, in fact, expressed stronger preference for working alone? These and other questions were on my mind when I went into the two Excursions classrooms with the final draft of the Classroom Preferences Questionnaire. 


\section{CHAPTER IV}

\section{RESEARCH METHODOLOGY}

\section{RESEARCH QUESTIONS REVISITED}

In developing and field-testing the Classroom Preferences Questionnaire, I felt I'd been able to identify classroom activities, approaches to learning, and modes of social interaction that matched, or at least held to the spirit of Gardner's multiple intelligences. Furthermore, the questionnaire had proved to be relatively quick and easy to administer, and comprehensible as well as readable to a fair range of second graders. In effect, I had answered my first two research questions, and needed to find out whether children's expressed preferences matched their actual classroom performance. Would children who indicated strong preference for mathematical activities actually demonstrate any particular skill or enthusiasm for mathematical work in the classroom, and would their preference for such activity be duly noted by teachers? Would youngsters who indicated preference for using such receptive approaches to learning as reading, listening, watching, and planning actually exhibit these behaviors in daily work? To investigate these questions, I planned to administer the Classroom Preferences Questionnaire to students in the two classrooms in which I'd observed Math Excursions units earlier. Having spent six weeks in one classroom and three in the other, I'd collected enough work samples to compare children's questionnaire responses with their performance in several domains. In addition, I planned to have the teachers fill out questionnaires on each child, seeking again to find con- 
nections between students' expressed preferences and teachers' perceptions and observations of children's behavior. The combination of quantitative and qualitative data, I knew, would provide more powerful answers to my questions than considering either in isolation.

\section{CLASSROOM OVERVIEWS}

The first class in which I'd observed was Mrs. Janet Johnstones's second grade at Sacramento School in the Parkrose District, located in East Multnomah County. Sacramento is a K-6 school that serves about 450 children, most of whom come from average to very low income households. Mrs. Johnstone had 24 students in her class this year, 15 boys and 9 girls. The second class, Ms. Veronica Parachinni's at Duniway School, located in Eastmoreland, was only thirty minutes from Sacramento, but sometimes seemed a world away. Duniway School, part of the Portland district, serves about 480 students, most of whom come from middle to upper income households. There is a sprinkling of lower income children bussed in from Sellwood, but many of Ms. Parachinni's 29 children (12 boys and 17 girls) seemed bigger, older, and more self-assured than Mrs. Johnstone's students.

Despite some differences in the students with whom they work, Mrs. Johnstone's and Ms. Parachinni's teaching methods, assessment techniques, and educational goals are similar. Both favor a whole-language approach to reading and writing, in which students often select their own reading materials and choose their own writing topics. Children are rarely grouped by ability, but meet to share and discuss literature as a whole class or in small interest groups. Mathematics in both classrooms is activity-based. Concrete models are used by children and teachers alike as a way to understand concepts, and a premium is 
placed on problem-solving rather than arriving at correct answers quickly. Discussion of multiple solutions is encouraged in both classrooms, particularly Ms. Parachinni's. Art instruction in Ms. Parachinni's room is discipline-based, while in Mrs. Johnstone's class it's often related to ongoing math, literature, or social studies projects. Both teachers facilitate study of life-cycles in science, and have dabbled in science-design technology for the last year or two.

Direct observation, individual interviews, and performance samples are favored by both teachers, while paper-and-pencil assessments are rarely used. This year, Ms. Parachinni engaged her students in developing their own portfolios, while Mrs. Johnstone spent more time than ever watching individuals and small groups at work during a variety of classroom activities. Both want children to love learning, feel comfortable taking risks, and have a sense of community and comfort in their classrooms. Ms. Parachinni, in particular, emphasizes the importance of student autonomy, and constantly encourages children to find their own methods of solving problems of all kinds and resolving conflicts. My observations of both Ms. Parachinni and Mrs. Johnstone in action led me to believe they are highly competent, innovative, and likely to be aware of children's behavior across a variety of domains.

\section{ADMINISTERING THE CLASSROOM PREFERENCES QUESTIONNAIRE TO STUDENTS}

After securing the cooperation of school administrators and participating teachers, I visited each classroom and briefly explained my project to the students. I asked that they take permission slips home to their parents to be signed and returned as quickly as possible (see Appendix $\mathrm{C}$ ). When I came back to the classrooms one week later, I found that twenty children in Ms. Parachinni's 
class and seventeen in Mrs. Johnstone's had obtained permission from their parents. Students who had not returned the signed forms were permitted to participate in the initial presentation of the questionnaire, but asked to read or write quietly as the others completed the instrument. Presentation of the questionnaire took about twenty minutes and consisted of a second explanation of the project (to develop a questionnaire that would help teachers understand what students most preferred to do in the classroom), a discussion of the categories using illustrated charts, and a demonstration of the paired choice marking system, in which children were instructed to respond to each question by circling the choice they most preferred of the two (see Figure 7). If neither choice appealed, students were to circle the most tolerable, and if both appealed, they were encouraged to try to choose the one that seemed the "best".

Would you rather work

\begin{tabular}{llll}
\hline $\begin{array}{l}\text { with a small group of } \\
3 \text { or } 4 \text { kids }\end{array}$ & or & or \\
\hline with a partner? & or & $\begin{array}{l}\text { with a partner? } \\
\text { four kids? }\end{array}$ \\
\hline alone & or & alone? \\
\hline with a partner? & or & or with a small group of \\
\hline
\end{tabular}

Figure 7. Paired choice marking system.

Once the presentation was complete, students were requested to do their own work (and, in fact, were given questionnaire booklets that had been stapled in 
different orders), but encouraged to raise their hands if they had problems reading any of the words or understanding any of the items. Completion time ranged from 20 to 45 minutes, although I discovered that one child who'd taken 45 minutes had also illustrated her booklet rather nicely, and three others had taken it upon themselves to score their own questionnaires, a procedure I'd only explained in passing. Six or seven children in each class needed some help reading or understanding items, while two needed extensive help. As before, enthusiasm was high. Children seemed to enjoy indicating their preferences using the simple paired choice format. One child remarked that the questionnaire should be given several times a year because students' responses were likely to change. She herself would have never have chosen writing as her best subject at the beginning of the year, she explained, but now it was her favorite.

\section{ADMINISTERING THE CLASSROOM PREFERENCES QUESTIONNAIRE TO TEACHERS}

To help insure that they had equivalent understandings of the questionnaire items and marking procedures, the teachers were asked to sit in on the presentation made to students, and allowed to help individual children with any reading or comprehension problems they encountered. Once the students had finished working, the teachers were asked to complete questionnaires on all participating children. Their judgments were to be based on their own perceptions and observations of students' actual classroom behavior over the year. This process took Mrs. Johnstone about two hours, and Ms. Parachinni about two hours and thirty minutes. Both teachers reported that some of the items were difficult to mark for some students - they felt as if they were guessing sometimes rather than making informed choices - but seemed to find the task interesting. 


\section{DATA ANALYSIS METHODS - SCORING STUDENTS' AND TEACHERS' RESPONSES}

Once all the questionnaires were completed, students' and teachers' responses under each category were tallied and ranked side-by-side on a score sheet to allow easy comparison. Those activities ranked first and second under each category were marked with highlighter pens to show whether they were linguistic (green), logical-mathematical (pink), spatial (yellow), kinesthetic (orange), or peer-oriented, which was interpreted as interpersonal (blue). First choice activities were marked with solid lines and assigned two points; second choice activities were marked with dotted lines and assigned one point (see example below). ${ }^{4}$ In this manner, I was able to draw up student's overall preference profiles, and teachers' perceptions of students' profiles under each subheading . Nicky, whose score sheet for preferred activities is shown above, for instance, ranked reading, words, story, and story illustration first choice, and word problems second choice, for a total of 9 points under linguistic preferences $[(4 \times 2)+1=9]$. He ranked numbers and computation first choice and math second choice for a total of 5 points under mathematical preferences $[(2 \times 2)+1=5]$, and drawing maps as a second choice, which gave him one point under spatial preferences (see summary below).

4 To organize these tables, I ordered the Ranking Comparison Sheets from highest to lowest level of agreement between students' expressed preferences and teachers' perceptions in the area of classroom activities. It was interesting to note the correlation, or lack thereof, between levels of agreement when the other areas of consideration were added to the chart. 
Ranking Comparison Child's Name Nicky

Teacher_Johnstone

Date_ 5/27/92

Preferred Activities

\begin{tabular}{|c|c|c|c|c|}
\hline Subject & Self Tally & Self Rank & Teacher Tally & Teacher Rank \\
\hline reading & 11111 & 1 & 111 & 2 \\
\hline writing & 11 & 3 & 1 & 4 \\
\hline math & 111 & 2 & 1111 & 1 \\
\hline art & 1 & 4 & & 5 \\
\hline science & & 5 & 11 & 3 \\
\hline Tools & Self Tally & Self Rank & Teacher Tally & Teacher Rank \\
\hline words & 111 & 1 & 111 & 1 \\
\hline numbers & 11 & 2 & 11 & 2 \\
\hline diagrams & & 4 & 1 & 3 \\
\hline objects & 1 & 3 & & 4 \\
\hline Language & Self Tally & Self Rank & Teacher Tally & Teacher Rank \\
\hline story & 11 & 1 & 11 & 1 \\
\hline $\begin{array}{l}\text { math story } \\
\text { problem }\end{array}$ & 1 & 2 & 1 & 2 \\
\hline instructions & & 3 & & 3 \\
\hline Math & Self Tally & Self Rank & Teacher Tally & Teacher Rank \\
\hline $\begin{array}{l}\text { word prob- } \\
\text { lems }\end{array}$ & 1 & 2 & & 3 \\
\hline computation & 11 & 1 & 1 & 2 \\
\hline $\begin{array}{l}\text { spatial prob- } \\
\text { lems }\end{array}$ & & 3 & 11 & 1 \\
\hline Art & Self Tally & Self Rank & Teacher Tally & Teacher Rank \\
\hline $\begin{array}{l}\text { story illustra- } \\
\text { tion }\end{array}$ & 11 & 1 & & 3 \\
\hline a pattern & & 3 & 1 & 2 \\
\hline a map & 1 & 2 & 11 & 1 \\
\hline
\end{tabular}


Nicky's Expressed Preference Profile for Classroom Activities

\begin{tabular}{|l|l|l|l|}
\hline Preferred Activities & Linguistic Activities & $\begin{array}{l}\text { Logical-Mathematical } \\
\text { Activities }\end{array}$ & Spatial Activities \\
\hline First Choice & 1111 & 1 & \\
\hline Second Choice & 1 & 111 & 1 \\
\hline Total Points & $9[(4 \times 2)+1]$ & $5[2+(3 \times 1)]$ & $1[1 \times 1]$ \\
\hline
\end{tabular}

Thus, Nicky expressed strong preference for linguistic activities, some preference for logical-mathematical activities, and very low preference for spatial activities. Mrs. Johnstone's perceptions of Nicky did not correspond to his expressed preferences, however. When her responses were tallied, ranked, and assigned preference points, it was clear that she perceived him to be almost equally balanced in linguistic, mathematical, and spatial strength (see summary below).

Mrs. Johnstone's Perceptions of Nicky's Preferred Classroom Activities

\begin{tabular}{|l|l|l|l|}
\hline Preferred Activities & Linguistic Activities & $\begin{array}{l}\text { Logical-Mathematical } \\
\text { Activities }\end{array}$ & Spatial Activities \\
\hline First Choice & 11 & 1 & 11 \\
\hline Second Choice & 1 & 1111 & \\
\hline Total Points & $5[(2 \times 2)+1]$ & $5[1+(4 \times 1)]$ & $4[2 \times 2]$ \\
\hline
\end{tabular}

Children's and teachers' responses under the other two subheadings were also scored as described above to profile students' preferred methods of learning and social orientation, and teachers' perceptions of youngsters' inclinations (see examples of completed Ranking Comparison Score Sheets in Appendix D).

Preferences for such kinesthetic ways of working as using objects, taking things apart or using them to understand how they work, building inventions, and using manipulatives to solve math problems were also noted. Children who ranked three or more of these methods as most preferred ways of working were desig- 
nated as having strong kinesthetic preferences.

Nicky's overall profile on the Classroom Preferences Questionnaire indicated strong preference for linguistic activities ( 9 points linguistic, 5 points logicalmathematical, and 1 point spatial); equal preference for receptive and expressive approaches to learning ( 6 points for each, with 3 points indicated for kinesthetic ways of working out of a possible 10); and a fair preference for working with peers ( 2 points self orientation, 4 points peer-orientation, 0 points adult orientation). Although the teacher's assessment of Nicky's preferred activities didn't match his expressed preferences, her perceptions of his favorite ways to work and interact with others were very close ( 6 points receptive, 6 points expressive, 5 points kinesthetic; 3 points self-oriented, 3 points peer oriented - see summary below).

\section{COMPARING STUDENTS' AND TEACHERS' RESPONSES}

To investigate the similarities and differences between students' and teachers' questionnaire responses, the results of individuals' Ranking Comparison Sheets were first analyzed informally. Differences in specific tally mark placements and item rankings were examined, as well as overall preference profiles. That is, I noted with interest that Anita's expressed preferences for linguistic activities, receptive methods of learning, and working by herself were mirrored quite closely by her teacher's perceptions. On the other hand, Eden's expressed preferences for spatial activities, receptive methods of learning, and interaction with adults did not match her teacher's perceptions in any way.

Unfortunately, attempts to compare students' preferences and teachers' perceptions in a more quantitative fashion proved fruitless, due to the fact that preference point totals varied considerably. Eric and his teacher, for instance, were in 
Comparison of Student Preferences and Teacher Perceptions (Nicky and Mrs. Johnstone)

\begin{tabular}{|c|c|c|c|c|c|c|}
\hline & $\begin{array}{l}\text { Student } \\
\text { (Nicky) }\end{array}$ & & & $\begin{array}{l}\text { Teacher (Mrs. } \\
\text { Johnstone) }\end{array}$ & & \\
\hline $\begin{array}{l}\text { Preferred } \\
\text { Activities }\end{array}$ & $\begin{array}{l}\text { Linguistic } \\
\text { Activities }\end{array}$ & $\begin{array}{l}\text { Logical-Math } \\
\text { Activities }\end{array}$ & $\begin{array}{l}\text { Spatial } \\
\text { Activities }\end{array}$ & $\begin{array}{l}\text { Linguistic } \\
\text { Activities }\end{array}$ & $\begin{array}{l}\text { Logical-Math } \\
\text { Activities }\end{array}$ & $\begin{array}{l}\text { Spatial } \\
\text { Activities }\end{array}$ \\
\hline First Choice & 1111 & 1 & & 11 & 1 & 11 \\
\hline $\begin{array}{l}\text { Second } \\
\text { Choice }\end{array}$ & 1 & 111 & 1 & 1 & 1111 & \\
\hline Total Points & 9 & 5 & 1 & 5 & 5 & 4 \\
\hline $\begin{array}{l}\text { Preferred } \\
\text { Methods of } \\
\text { Learning }\end{array}$ & Receptive & Expressive & Kinesthetic & Receptive & Expressive & Kinesthetic \\
\hline First Choice & 111 & 1 & 1 & 11 & 11 & 11 \\
\hline $\begin{array}{l}\text { Second } \\
\text { Choice }\end{array}$ & & 1111 & 1 & 11 & 11 & 1 \\
\hline Total Points & 6 & 6 & 3 & 6 & 6 & 5 \\
\hline $\begin{array}{l}\text { Preferred } \\
\text { Social } \\
\text { Orientation }\end{array}$ & Self & Peer & Adult & Self & Peer & Adult \\
\hline First Choice & 1 & 1 & & 1 & 1 & \\
\hline $\begin{array}{l}\text { Second } \\
\text { Choice }\end{array}$ & & 11 & & 1 & 1 & \\
\hline Total Points & 2 & 4 & 0 & 3 & 3 & 0 \\
\hline
\end{tabular}

close agreement about his preferences for mathematical and spatial activities, but efforts to equate their responses numerically didn't work because Eric's scored questionnaire assigned 2 preference points to linguistic activities, 5.5 to mathematical activities, and 6 to spatial pursuits, for a total of 13.5, while his teacher's responses resulted in 1 point assigned to linguistic activities, 5 to mathematical, and 9 to spatial, for a total of 15 . This disparity was due to ties between items in two categories on Eric's questionnaire. Differences between preference point totals occurred fairly frequently when comparing students' and teachers' responses to preferred classroom activities, but were even more glaring in the area of pre- 
ferred methods of learning. Furthermore, the number of points to be contrasted under preferred modes of social interaction was too small to be considered seriously, so in the end, I decided to compare students' and teachers' responses on the basis of overall profiles rather than preference points.

The level of agreement between student's and teacher's responses was considered to be high if the overall preference profiles indicated by both were identical, or close to it. Agreement level was designated moderate if: a) the child's top preference remained the same but points in the other areas were allocated quite differently by the teacher; $b$ ) a student expressed a strong preference for one category but was seen by the teacher to have preferences balanced equally between that area and another; or c) the student indicated preferences balanced between two areas and the teacher allocated more preference points to one of those areas than the other. Agreement level was considered low if: a) the student expressed strong preference for one area but was seen by the teacher to have interests balanced in all three areas; b) if the student expressed balanced interest in all three areas but the teacher perceived a strong preference in one area only; or c) the child expressed preference for areas not identified at all by the teacher.

Suppose, for example, that a student's questionnaire allocates 8 preference points to linguistic activities, 3 to mathematical, and 4 to spatial activities. It appears, then, that this child has strong preferences for linguistic activities.

Suppose, then, that the questionnaire the teacher fills out on this child allocates 3 points to linguistic activities, 7 to mathematical, and 5 to spatial. She sees him as a student whose preferences are nearly balanced in the domains of math and spatial activity. The level of agreement between the teacher and this child in the area of classroom activities would be considered low. In the area of learning methods, however the child has allocated 2 points to receptive approaches and 8 to ex- 
pressive. The teacher has allocated 4 points to receptive and 8 to expressive for him. Both teacher and student agree that he prefers expressive methods of learning; their level of agreement is high. Finally, the student has allocated 3 preference points to self-oriented work and 3 to peer-oriented, while the teacher has assigned 4 points to self-oriented work and 2 to peer-oriented. She sees this student as a bit more inclined to prefer working by himself, while he expresses a balanced preference for self-oriented and peer-oriented work. The level of agreement between the two is moderate.

\section{INVESTIGATING THE CONNECTION BETWEEN STUDENTS' EXPRESSED PREFERENCES AND CLASSROOM PERFORMANCE}

In order to explore the connection between students' expressed preferences and their actual performance, as perceived by teachers and demonstrated in the classroom, the Excursions work of four children was selected for more in-depth examination. This group included three children from one class who expressed stronger preference for linguistic, mathematical, or spatial activity than any of their classmates, as well as one child who expressed equal preference for all three types of activity. Linguistic, mathematical, and spatial work samples from each of the four were examined for similarities, differences, and signs of particular skill or enthusiasm in the area of strongest preference.

In addition, four children in each class were identified for further study via work sample analysis. This group was to have included two students from each class who expressed strong preference for language activity; two, a strong preference for mathematical activity; and two, spatial. Unfortunately, I could not identify anyone in Mrs. Johnstone's class with particularly strong linguistic preferences, nor anyone in Ms. Parachinni's with strong expressed preferences for 
mathematical activities, so the potential pool of twelve was reduced to eight. Of the two in each existing group, however, there was one whose overall preference profile for classroom activities matched the teacher's perceptions quite closely and one for whom there was little agreement (see Figures 8 and 9).

\begin{tabular}{|l|l|l|l|}
\hline & $\begin{array}{l}\text { Strong Expressed } \\
\text { Linguistic Preference }\end{array}$ & $\begin{array}{l}\text { Strong Expressed } \\
\text { Mathematical } \\
\text { Preference }\end{array}$ & $\begin{array}{l}\text { Strong Expressed } \\
\text { Spatial Preference }\end{array}$ \\
\hline $\begin{array}{l}\text { High Agreement } \\
\text { Between Student and } \\
\text { Teacher }\end{array}$ & Becky & $\mathrm{X}$ & Jason \\
\hline $\begin{array}{l}\text { Low Agreement } \\
\text { Between Student and } \\
\text { Teacher }\end{array}$ & $\begin{array}{l}\text { Spencer } \\
\text { (Teacher sees Spencer } \\
\text { as someone with high } \\
\text { preference for math } \\
\text { and spatial activities.) }\end{array}$ & $\mathrm{X}$ & $\begin{array}{l}\text { Eden } \\
\text { (Teacher sees Eden as } \\
\text { someone with high } \\
\text { preference for lan- } \\
\text { guage activities.) }\end{array}$ \\
\hline $\begin{array}{l}\text { Type of Task } \\
\text { Examined }\end{array}$ & Linguistic & Mathematical & Spatial \\
\hline
\end{tabular}

Figure 8. Students from Ms. Parachinni's class.

\begin{tabular}{|l|l|l|l|}
\hline & $\begin{array}{l}\text { Strong Expressed } \\
\text { Linguistic Preference }\end{array}$ & $\begin{array}{l}\text { Strong Expressed } \\
\text { Mathematical } \\
\text { Preference }\end{array}$ & $\begin{array}{l}\text { Strong Expressed } \\
\text { Spatial Preference }\end{array}$ \\
\hline $\begin{array}{l}\text { High } \\
\text { Agreement Between } \\
\text { Student and Teacher }\end{array}$ & $\mathrm{X}$ & Jared & Richard \\
\hline $\begin{array}{l}\text { Low Agreement } \\
\text { Between Student and } \\
\text { Teacher }\end{array}$ & $\mathrm{X}$ & $\begin{array}{l}\text { Jay } \\
\text { (Teacher sees Jay as } \\
\text { someone with very } \\
\text { strong preference for } \\
\text { spatial activities.) }\end{array}$ & $\begin{array}{l}\text { Vicky } \\
\text { (Teacher sees Vicki as } \\
\text { someone with very } \\
\text { strong linguistic pref- } \\
\text { erences.) }\end{array}$ \\
\hline $\begin{array}{l}\text { Type of Task } \\
\text { Examined }\end{array}$ & Linguistic & Mathematical & Spatial \\
\hline
\end{tabular}

Figure 9. Students from Mrs. Johnstone's Class.

Jared and Jay both expressed strong preference for mathematical activities, although Jay also indicated almost equal interest in spatial activities. Mrs. 
Johnstone's responses on the questionnaires she completed for the boys indicated a high level of agreement with Jared, but a much lower level of agreement with Jay, whom she saw as preferring spatial activities almost exclusively. I examined the work of both boys on the same mathematical task to investigate possible reasons for high agreement between student preference and teacher perception in the first case, and much less agreement in the second. Similar analysis was conducted on each pair of children in the selected group of eight. 


\section{CHAPTER V}

\section{RESULTS AND ANALYSIS}

\section{STUDENTS' RESPONSES - PREFERRED CLASSROOM ACTIVITIES}

As I scored and analyzed students' responses to the Classroom Preferences Questionnaire, I noticed that they fell into four groups with respect to preferred classroom activities: children who expressed strong preference for linguistic activity, children who expressed strong preference for logical mathematical activity, children who expressed strong preference for spatial activity, and students who expressed nearly equal preference for two, or even all three types of activity (see Tables III and IV).

Although my purpose was not to compare the classes, it was interesting to note that roughly a third to a half of the students in each class expressed balanced interests of one sort or another, while the other portion had more "extreme" preferences. Close to an equal number in each class expressed high preference for spatial activities (5 out of 17 in Mrs. Johnstone's room and 6 out of 20 in Ms. Parachinni's), while a higher number expressed strong preferences for linguistic activities in Ms. Parachinni's room (5 out of 20, as opposed to 1 out of 17). On the other hand, 4 of Mrs. Johnstone's students expressed strong preference for mathematical activities, while none of the students in Ms. Parachinni's class did so. 
TABLE III

MRS. JOHNSTONE'S CLASS

CLASSROOM ACTIVITY PREFERENCE PROFILES

Preference Point Allocation

\begin{tabular}{|l|l|l|l|l|}
\hline $\begin{array}{l}\text { Student } \\
\text { Code \# }\end{array}$ & Ling. & Math & Spatial & $\begin{array}{l}\text { Overall Preference Profile for Classroom } \\
\text { Activities }\end{array}$ \\
\hline 1 & 9 & 5 & 1 & Linguistic \\
\hline 8 & 5 & 3 & 7 & Spatial with a linguistic "backup" \\
\hline 12 & 3 & 5 & 7 & Spatial with a math "backup" \\
\hline 7 & 1 & 5 & 9 & Spatial \\
\hline 10 & 3 & 2 & 10 & Spatial \\
\hline 11 & 3 & 4 & 8 & Spatial \\
\hline 16 & 3.5 & 5 & 3.5 & Mathematical \\
\hline 15 & 5 & 8 & 2 & Mathematical \\
\hline 17 & 1.5 & 6.5 & 4 & Mathematical \\
\hline 13 & 5 & 8 & 2 & Mathematical \\
\hline 3 & 7 & 2 & 6 & Linguistic/Spatial Balance \\
\hline 14 & 2 & 7 & 6 & Mathematical/Spatial Balance \\
\hline 2 & 5 & 4 & 1 & Linguistic/Mathematical Balance \\
\hline 4 & 5 & 5.5 & 4.5 & Balance - All Three \\
\hline 6 & 6.5 & 4.5 & 6.5 & Balance - All Three \\
\hline 5 & 4 & 5.5 & 4.5 & Balance - All Three \\
\hline
\end{tabular}


TABLE IV

\section{MS. PARACHINNI'S CLASS \\ CLASSROOM ACTIVITY PREFERENCE PROFILES}

Preference Point Allocation

\begin{tabular}{|l|l|l|l|l|}
\hline $\begin{array}{l}\text { Student } \\
\text { Code \# }\end{array}$ & Ling. & Math & Spatial & $\begin{array}{l}\text { Overall Preference Profile for Classroom } \\
\text { Activities }\end{array}$ \\
\hline 6 & 8 & 3 & 4 & Linguistic \\
\hline 3 & 7 & 3 & 5 & Linguistic with a spatial "backup" \\
\hline 2 & 9 & 4 & 2 & Linguistic \\
\hline 1 & 8 & 2 & 2 & Linguistic \\
\hline 4 & 7 & 2 & 5 & Linguistic with a spatial "backup" \\
\hline 12 & 4 & 1 & 10 & Spatial \\
\hline 14 & 4.5 & 2.5 & 7 & Spatial \\
\hline 16 & 1 & 4 & 10 & Spatial \\
\hline 9 & 2 & 4 & 9 & Spatial \\
\hline 13 & 3 & 2 & 10 & Spatial \\
\hline 15 & 5 & 3 & 7 & Spatial with a linguistic "backup" \\
\hline 5 & 7 & 2 & 6 & Linguistic/Spatial Balance \\
\hline 10 & 5 & 2 & 5 & Linguistic/Spatial Balance \\
\hline 19 & 4.5 & 5.5 & 2 & Linguistic/Math Balance \\
\hline 17 & 2 & 5 & 6.5 & Math/Spatial Balance \\
\hline 18 & 2 & 5.5 & 6 & Math/Spatial Balance \\
\hline 7 & 5 & 5 & 5 & Balance - All Three \\
\hline 9 & 4 & 5 & 6 & Balance - All Three \\
\hline 8 & 6 & 4 & 5 & Balance - All Three \\
\hline 11 & 5.5 & 5.5 & 4.5 & Balance - All Three \\
\hline 20 & 5 & 6 & 4 & Balance - All Three \\
\hline & & & & \\
\hline
\end{tabular}




\section{STUDENT RESPONSES - PREFERRED METHODS OF LEARNING}

While one might have anticipated some connection between activity preference and favored method of learning - anticipated, for instance that children who indicated strong spatial preferences would choose very active methods of working, while linguistic-preference students might have been more inclined to watch, read, and listen - the results of the second section of the questionnaire did not establish any clear correlation, but seemed, instead, to support the developmental notion that young children generally prefer more expressive approaches to learning.

\section{TABLE V}

\section{BOTH CLASSES}

Summary of Preferred Learning Methods

\begin{tabular}{|l|l|l|l|l|}
\hline & $\begin{array}{l}\text { Receptive } \\
\text { (listening, figur- } \\
\text { ing things out } \\
\text { mentally, watch- } \\
\text { ing, reading } \\
\text { about) }\end{array}$ & $\begin{array}{l}\text { Expressive } \\
\text { (telling, writing, } \\
\text { drawing, using } \\
\text { manipulatives, } \\
\text { taking things } \\
\text { apart, using } \\
\text { things, building) }\end{array}$ & $\begin{array}{l}\text { Receptive and } \\
\text { Expressive } \\
\text { Balance }\end{array}$ & $\begin{array}{l}\text { Kinesthetic (using } \\
\text { manipulatives to } \\
\text { solve problems, } \\
\text { taking things } \\
\text { apart or using } \\
\text { them, building) }\end{array}$ \\
\hline $\begin{array}{l}\text { Mrs. Johnstone's } \\
\text { Students (N=17) }\end{array}$ & 0 & 16 & 1 & 11 \\
\hline $\begin{array}{l}\text { Ms. Parachinni's } \\
\text { Students (N = 20) }\end{array}$ & 5 & 10 & 5 & 7 \\
\hline
\end{tabular}

As shown in Table $\mathrm{V}$ above, sixteen out of the seventeen participating students in Mrs. Johnstone's class, and ten out of twenty in Ms. Parachinni's, indicated strong preference for such expressive modes of learning as writing, drawing, using manipulatives, taking things apart or using them to understand how they work, and building inventions rather than planning or writing about them. One student in Mrs. Johnstone's class and five in Ms. Parachinni's indicated pref- 
erence for an equal mixture of expressive and receptive learning methods, while five in Ms. Parachinni's showed strong preference for receptive methods. Of these eleven students, 3 expressed preference for linguistic activities in the first part of the questionnaire; 1 , math; 4, spatial; and 3, a balance, belying the notion that children with spatial preferences will always choose spatial and kinesthetic modes of working.

Interesting, also, is the fact that eleven ( 6 boys and 5 girls) out of Mrs. Johnstone's seventeen participating students (10 boys and 7 girls) indicated strong preference for such kinesthetic approaches to learning as using objects, taking things apart, building inventions, and using manipulatives to solve math problems, while only seven (4 boys and 3 girls) of Ms. Parachinni's twenty ( 7 boys and 13 girls) were so inclined. There are many conceivable explanations for these results, including differences in the age and gender composition of the two groups, as well as children's classroom experiences and expectations.

\section{STUDENT RESPONSES - PREFERRED MODES OF SOCIAL INTERACTION}

In light of the fact that most teachers ask children to spend a great deal of time engaged in whole-group lessons, and more recently, working with partners or in small cooperative groups, I found the results of the third section of the Classroom Preferences Questionnaire, summarized in Table VI most interesting.

While whole class instruction is surely one of the most efficient modes for teachers, it did not appear to be especially popular with these children, only two of whom express any interest at all in working with the entire group. Nor did it seem that every child was as keen on working with partners or in small groups as current trends in cooperative learning might dictate. After the questionnaire had been administered in Mrs. Johnstone's class, I asked several youngsters to 


\section{TABLE VI}

\section{BOTH CLASSES}

Summary of Social Orientation Preferences

\begin{tabular}{|l|l|l|l|l|}
\hline & $\begin{array}{l}\text { Self-Oriented } \\
\text { (Prefers to work } \\
\text { alone on own } \\
\text { ideas.) }\end{array}$ & $\begin{array}{l}\text { Peer-Oriented } \\
\text { (Prefers to work } \\
\text { with a partner or } \\
\text { small group on } \\
\text { own ideas or } \\
\text { ideas developed } \\
\text { by the group.) }\end{array}$ & $\begin{array}{l}\text { Adult-Oriented } \\
\text { (Prefers to work } \\
\text { with the entire } \\
\text { lass, or to carry } \\
\text { out ideas sug- } \\
\text { gested by the } \\
\text { teacher) }\end{array}$ & $\begin{array}{l}\text { Balance of Two or } \\
\text { Three } \\
\text { Orientations }\end{array}$ \\
\hline $\begin{array}{l}\text { Mrs. Johnstone's } \\
\text { Students (N=17) }\end{array}$ & 7 & 5 & 1 & $\begin{array}{l}4 \\
\text { (3 self/peer } \\
1 \text { peer/adult) }\end{array}$ \\
\hline $\begin{array}{l}\text { Ms. Parachinni's } \\
\text { Students (N=20) }\end{array}$ & 4 & 8 & 1 & $\begin{array}{l}7 \\
\text { (6 self/peer } \\
1 \text { peer/adult) }\end{array}$ \\
\hline
\end{tabular}

explain their preferences, and received the following responses:

On Working Alone:

Tyrone: I like being on my own so a partner doesn't have to boss me around - so I can do my own thing.

Richard: I like working by myself'cause you can do more when you're working by yourself. Because you can concentrate. My partner always takes up timr'cause he says he has to cut the string. I could have more time if I worked by myself.

On Working With the Whole Class:

Sally: I hate working with the whole class! I'm embarrassed to do things with everybody. Some kids are mean - I don't want to work with them, but I have to work with everyone in the whole class when we're together. Also, the teacher never picks me even if I raise my hand.

Shawn: I like working with the whole class. Because everyone like working with Mrs. Johnstone because she does stuff we like.

On Working With a Partner:

Nicky: Partners is good because then you can both think of what to do. I don't have to think of stuff by myself. If it's something real fun like making our pet shop, I like to do it with a partner. 
On Working With a Small Group:

Karin: I like being in a small group because it's easier to work and stuff. In the Gingerbread Village, we glued down the sections and then put our houses and buildings on them. We worked in small groups in the post office, and sometimes we do during reading.

\section{COMPARISON OF STUDENTS' AND TEACHERS' RESPONSES}

Comparison of the overall preference profiles expressed by students and perceived by their teachers didn't appear to show much in the way of patterns or trends, aside from the fact that the inclinations of a few children seemed to be very well-known or "well-read" by their teachers, while others' expressed preferences didn't seem to correspond to adult perceptions at all. Most students, however, fell somewhere in between (see Tables VII and VIII5, pages 44-47).

As demonstrated in the tables above, there seemed to be a few cases in each class of nearly total agreement between students' expressed preferences and the teacher's perceptions, and a few instances of almost complete mismatch. Most fell somewhere in between. One student's expressed preferences for math and working with peers appear to have been perceived by her teacher, while her inclinations toward more receptive methods of learning were not. Likewise, a student who expressed high preference for spatial activities, peer-oriented work, and expressive methods of learning was apparently viewed by his teacher as someone who had equal preference for linguistic and spatial activities, preferred to work by himself, but delighted in building, drawing, writing, and showing his work with manipulatives. Mismatch or match between student preferences and

5 To organize these tables, I ordered the Ranking Comparison Sheets from highest to lowest level of agreement between students' expressed preferences and teachers' perceptions in the area of classroom activities. It was interesting to note the correlation, or lack thereof, between levels of agreement when the other areas of consideration were added to the chart. 


\section{TABLE VII}

MRS. JOHNSTONE'S CLASS

COMPARISON OF OVERALL PREFERENCE PROFILES AS EXPRESSED BY STUDENTS AND PERCEIVED BY TEACHER

\begin{tabular}{|c|c|c|c|}
\hline $\begin{array}{l}\text { St. } \\
\#\end{array}$ & $\begin{array}{l}\text { Student's Expressed } \\
\text { Preference Profile }\end{array}$ & $\begin{array}{l}\text { Teacher's Perceived } \\
\text { Preference Profile }\end{array}$ & Level of Agreement \\
\hline 13 & $\begin{array}{l}\text { Math } \\
\text { Expressive } \\
\text { Peer }\end{array}$ & $\begin{array}{l}\text { Math } \\
\text { Expressive } \\
\text { Peer }\end{array}$ & $\begin{array}{l}\text { High } \\
\text { High } \\
\text { High }\end{array}$ \\
\hline 11 & $\begin{array}{l}\text { Spatial } \\
\text { Expressive } \\
\text { Self }\end{array}$ & $\begin{array}{l}\text { Spatial } \\
\text { Expressive/Receptive } \\
\text { Balance } \\
\text { Self }\end{array}$ & $\begin{array}{l}\text { High } \\
\text { Moderate } \\
\text { High }\end{array}$ \\
\hline 7 & $\begin{array}{l}\text { Spatial } \\
\text { Expressive } \\
\text { Peer }\end{array}$ & $\begin{array}{l}\text { Spatial } \\
\text { Expressive } \\
\text { Adult }\end{array}$ & $\begin{array}{l}\text { High } \\
\text { High } \\
\text { Low }\end{array}$ \\
\hline 10 & $\begin{array}{l}\text { Spatial } \\
\text { Expressive } \\
\text { Self }\end{array}$ & $\begin{array}{l}\text { Spatial } \\
\text { Expressive } \\
\text { Peer }\end{array}$ & $\begin{array}{l}\text { High } \\
\text { High } \\
\text { Low }\end{array}$ \\
\hline 6 & $\begin{array}{l}\text { Linguistic/Math/Spatial Bal. } \\
\text { Expressive } \\
\text { Self/Peer/Adult Balance }\end{array}$ & $\begin{array}{l}\text { Linguistic/Math/Spatial Bal. } \\
\text { Receptive } \\
\text { Peer }\end{array}$ & $\begin{array}{l}\text { High } \\
\text { Low } \\
\text { Low }\end{array}$ \\
\hline 5 & $\begin{array}{l}\text { Linguistic/Math/Spatial Bal. } \\
\text { Expressive } \\
\text { Self/Peer/Adult Balance }\end{array}$ & $\begin{array}{l}\text { Linguistic/Math/Spatial Bal. } \\
\text { Expressive } \\
\text { Peer }\end{array}$ & $\begin{array}{l}\text { High } \\
\text { High } \\
\text { Low }\end{array}$ \\
\hline 2 & $\begin{array}{l}\text { Linguistic/Math Balance } \\
\text { Expressive } \\
\text { Adult }\end{array}$ & $\begin{array}{l}\text { Linguistic } \\
\text { Expressive/Receptive } \\
\text { Balance } \\
\text { Peer/Adult Balance }\end{array}$ & $\begin{array}{l}\text { Moderate } \\
\text { Moderate } \\
\text { Moderate }\end{array}$ \\
\hline 3 & $\begin{array}{l}\text { Linguistic/Spatial Balance } \\
\text { Expressive } \\
\text { Self }\end{array}$ & $\begin{array}{l}\text { Spatial } \\
\text { Expressive } \\
\text { Self }\end{array}$ & $\begin{array}{l}\text { Moderate } \\
\text { High } \\
\text { High }\end{array}$ \\
\hline 17 & $\begin{array}{l}\text { Math } \\
\text { Expressive } \\
\text { Peer/Adult Balance }\end{array}$ & $\begin{array}{l}\text { Spatial/Math } \\
\text { Expressive } \\
\text { Peer/Adult Balance }\end{array}$ & $\begin{array}{l}\text { Moderate } \\
\text { High } \\
\text { High }\end{array}$ \\
\hline
\end{tabular}


TABLE VII

MRS. JOHNSTONE'S CLASS

COMPARISON OF OVERALL PREFERENCE PROFILES AS EXPRESSED BY STUDENTS AND PERCEIVED BY TEACHER

(continued)

\begin{tabular}{|c|c|c|c|}
\hline 15 & $\begin{array}{l}\text { Math with a Linguistic } \\
\text { "backup" } \\
\text { Expressive } \\
\text { Self/Peer Balance }\end{array}$ & $\begin{array}{l}\text { Linguistic with a Math } \\
\text { "backup" } \\
\text { Expressive } \\
\text { Peer/Adult Balance }\end{array}$ & $\begin{array}{l}\text { Moderate } \\
\text { High } \\
\text { Moderate }\end{array}$ \\
\hline 14 & $\begin{array}{l}\text { Math/Spatial Balance } \\
\text { Expressive } \\
\text { Self/Peer Balance }\end{array}$ & $\begin{array}{l}\text { Spatial } \\
\text { Expressive } \\
\text { Peer }\end{array}$ & $\begin{array}{l}\text { Moderate } \\
\text { High } \\
\text { Moderate }\end{array}$ \\
\hline 1 & $\begin{array}{l}\text { Linguistic } \\
\text { Expressive/Receptive } \\
\text { Balance } \\
\text { Peer }\end{array}$ & $\begin{array}{l}\text { Linguistic/Math/Spatial Bal. } \\
\text { Expressive/Receptive } \\
\text { Balance } \\
\text { Self/Peer Balance }\end{array}$ & $\begin{array}{l}\text { Low } \\
\text { High } \\
\text { Moderate }\end{array}$ \\
\hline 15 & $\begin{array}{l}\text { Math } \\
\text { Expressive } \\
\text { Peer }\end{array}$ & $\begin{array}{l}\text { Spatial } \\
\text { Expressive } \\
\text { Self }\end{array}$ & $\begin{array}{l}\text { Low } \\
\text { High } \\
\text { Low }\end{array}$ \\
\hline 9 & $\begin{array}{l}\text { Spatial } \\
\text { Expressive } \\
\text { Self/Peer/Adult Balanced }\end{array}$ & $\begin{array}{l}\text { Linguistic/Math/Spatial Bal. } \\
\text { Expressive } \\
\text { Peer/Self Balance }\end{array}$ & $\begin{array}{l}\text { Low } \\
\text { High } \\
\text { Moderate }\end{array}$ \\
\hline 8 & $\begin{array}{l}\text { Spatial with a linguistic back- } \\
\text { up } \\
\text { Expressive } \\
\text { Self }\end{array}$ & $\begin{array}{l}\text { Math } \\
\text { Expressive } \\
\text { Peer }\end{array}$ & $\begin{array}{l}\text { Low } \\
\text { High } \\
\text { Low }\end{array}$ \\
\hline 12 & $\begin{array}{l}\text { Spatial with a Math 'back- } \\
\text { up' } \\
\text { Expressive } \\
\text { Self }\end{array}$ & $\begin{array}{l}\text { Linguistic } \\
\text { Expressive } \\
\text { Self }\end{array}$ & $\begin{array}{l}\text { Low } \\
\text { High } \\
\text { High }\end{array}$ \\
\hline 4 & $\begin{array}{l}\text { Linguistic/Math/Spatial Bal. } \\
\text { Expressive } \\
\text { Self }\end{array}$ & $\begin{array}{l}\text { Spatial } \\
\text { Expressive } \\
\text { Peer }\end{array}$ & $\begin{array}{l}\text { Low } \\
\text { High } \\
\text { Low }\end{array}$ \\
\hline
\end{tabular}


TABLE VIII

MS. PARACHINNI'S CLASS

COMPARISON OF OVERALL PREFERENCE PROFILES AS EXPRESSED BY STUDENTS AND PERCEIVED BY THE TEACHER

\begin{tabular}{|c|c|c|c|}
\hline St.\# & $\begin{array}{l}\text { Student's Expressed } \\
\text { Preference Profile }\end{array}$ & $\begin{array}{l}\text { Teacher's Perceived } \\
\text { Preference Profile }\end{array}$ & Level of Agreement \\
\hline 1 & $\begin{array}{l}\text { Linguistic } \\
\text { Expressive } \\
\text { Self }\end{array}$ & $\begin{array}{l}\text { Linguistic } \\
\text { Expressive } \\
\text { Peer }\end{array}$ & $\begin{array}{l}\text { High } \\
\text { High } \\
\text { High }\end{array}$ \\
\hline 3 & $\begin{array}{l}\text { Linguistic with a Spatial } \\
\text { backup } \\
\text { Expressive } \\
\text { Peer }\end{array}$ & $\begin{array}{l}\text { Linguistic } \\
\text { Expressive } \\
\text { Peer }\end{array}$ & $\begin{array}{l}\text { High } \\
\text { High } \\
\text { High }\end{array}$ \\
\hline 4 & $\begin{array}{l}\text { Linguistic with a spatial } \\
\text { backup } \\
\text { Expressive } \\
\text { Self }\end{array}$ & $\begin{array}{l}\text { Linguistic } \\
\text { Expressive } \\
\text { Self }\end{array}$ & $\begin{array}{l}\text { High } \\
\text { High } \\
\text { High }\end{array}$ \\
\hline 13 & $\begin{array}{l}\text { Spatial } \\
\text { Receptive } \\
\text { Peer }\end{array}$ & $\begin{array}{l}\text { Spatial } \\
\text { Expressive } \\
\text { Self }\end{array}$ & $\begin{array}{l}\text { High } \\
\text { Low } \\
\text { Low }\end{array}$ \\
\hline 7 & $\begin{array}{l}\text { Linguistic/Math/Spatial Bal. } \\
\text { Expressive } \\
\text { Peer }\end{array}$ & $\begin{array}{l}\text { Linguistic/Math/Spatial Bal. } \\
\text { Expressive } \\
\text { Self/Peer/Adult Balance }\end{array}$ & $\begin{array}{l}\text { High } \\
\text { High } \\
\text { Low }\end{array}$ \\
\hline 11 & $\begin{array}{l}\text { Linguistic/Math/Spatial Bal. } \\
\text { Expressive } \\
\text { Peer/Adult Balance }\end{array}$ & $\begin{array}{l}\text { Linguistic/Math/Spatial Bal. } \\
\text { Expressive } \\
\text { Peer/Self Balance }\end{array}$ & $\begin{array}{l}\text { High } \\
\text { High } \\
\text { Moderate }\end{array}$ \\
\hline 2 & $\begin{array}{l}\text { Linguistic } \\
\text { Receptive } \\
\text { Self }\end{array}$ & $\begin{array}{l}\text { Linguistic/Math Balance } \\
\text { Receptive } \\
\text { Self }\end{array}$ & $\begin{array}{l}\text { Moderate } \\
\text { High } \\
\text { High }\end{array}$ \\
\hline 10 & $\begin{array}{l}\text { Linguistic/Spatial Balance } \\
\text { Expressive } \\
\text { Peer }\end{array}$ & $\begin{array}{l}\text { Spatial } \\
\text { Expressive } \\
\text { Peer }\end{array}$ & $\begin{array}{l}\text { Moderate } \\
\text { High } \\
\text { High }\end{array}$ \\
\hline 5 & $\begin{array}{l}\text { Linguistic/Spatial Balance } \\
\text { Receptive } \\
\text { Peer }\end{array}$ & $\begin{array}{l}\text { Linguistic } \\
\text { Expressive } \\
\text { Peer }\end{array}$ & $\begin{array}{l}\text { Moderate } \\
\text { Low } \\
\text { High }\end{array}$ \\
\hline 19 & $\begin{array}{l}\text { Linguistic/Math Balance } \\
\text { Receptive/Expressive } \\
\text { Balance } \\
\text { Self/Peer Balance }\end{array}$ & $\begin{array}{l}\text { Linguistic } \\
\text { Expressive } \\
\text { Self/Peer Balance }\end{array}$ & $\begin{array}{l}\text { Moderate } \\
\text { Moderate } \\
\text { High }\end{array}$ \\
\hline
\end{tabular}


TABLE VIII

MS. PARACHINNI'S CLASS

COMPARISON OF OVERALL PREFERENCE PROFILES AS EXPRESSED BY STUDENTS AND PERCEIVED BY THE TEACHER (continued)

\begin{tabular}{|c|c|c|c|}
\hline 18 & $\begin{array}{l}\text { Math/Spatial Balance } \\
\text { Expressive } \\
\text { Self }\end{array}$ & $\begin{array}{l}\text { Spatial with a Math Backup } \\
\text { Expressive } \\
\text { Self }\end{array}$ & $\begin{array}{l}\text { Moderate } \\
\text { High } \\
\text { High }\end{array}$ \\
\hline 16 & $\begin{array}{l}\text { Spatial } \\
\text { Receptive/Expressive } \\
\text { Balance } \\
\text { Peer }\end{array}$ & $\begin{array}{l}\text { Spatial with Linguistic } \\
\text { Backup } \\
\text { Expressive } \\
\text { Self }\end{array}$ & $\begin{array}{l}\text { Moderate } \\
\text { Moderate } \\
\text { Low }\end{array}$ \\
\hline 14 & $\begin{array}{l}\text { Spatial with a Linguistic } \\
\text { Backup } \\
\text { Expressive } \\
\text { Peer }\end{array}$ & $\begin{array}{l}\text { Spatial with a Math Backup } \\
\text { Expressive } \\
\text { Peer }\end{array}$ & $\begin{array}{l}\text { Moderate } \\
\text { High } \\
\text { High }\end{array}$ \\
\hline 17 & $\begin{array}{l}\text { Spatial/Math Balance } \\
\text { Expressive } \\
\text { Self/Peer Balance }\end{array}$ & $\begin{array}{l}\text { Math with a Spatial Backup } \\
\text { Receptive/Expressive } \\
\text { Balance } \\
\text { Self/Peer Balance }\end{array}$ & $\begin{array}{l}\text { Moderate } \\
\text { Moderate } \\
\text { High }\end{array}$ \\
\hline 8 & $\begin{array}{l}\text { Linguistic/Math/Spatial Bal. } \\
\text { Receptive/Expressive } \\
\text { Balance } \\
\text { Self/Peer Balance }\end{array}$ & $\begin{array}{l}\text { Linguistic/Spatial Balance } \\
\text { Receptive/Expressive } \\
\text { Balance } \\
\text { Peer }\end{array}$ & $\begin{array}{l}\text { Moderate } \\
\text { High } \\
\text { Moderate }\end{array}$ \\
\hline 9 & $\begin{array}{l}\text { Linguistic/Math/Spatial Bal. } \\
\text { Receptive } \\
\text { Peer }\end{array}$ & $\begin{array}{l}\text { Math/Spatial Balance } \\
\text { Receptive/Expressive } \\
\text { Balance } \\
\text { Peer } \\
\end{array}$ & $\begin{array}{l}\text { Moderate } \\
\text { Moderate } \\
\text { High }\end{array}$ \\
\hline 6 & $\begin{array}{l}\text { Linguistic } \\
\text { Expressive } \\
\text { Self/Peer Balance }\end{array}$ & $\begin{array}{l}\text { Math/Spatial Balance } \\
\text { Expressive } \\
\text { Self }\end{array}$ & $\begin{array}{l}\text { Low } \\
\text { High } \\
\text { Moderate }\end{array}$ \\
\hline 15 & $\begin{array}{l}\text { Spatial with a linguistic } \\
\text { Backup } \\
\text { Expressive } \\
\text { Self/Peer Balance }\end{array}$ & $\begin{array}{l}\text { Linguistic } \\
\text { Expressive } \\
\text { Peer }\end{array}$ & $\begin{array}{l}\text { Low } \\
\text { High } \\
\text { Moderate }\end{array}$ \\
\hline 12 & $\begin{array}{l}\text { Spatial } \\
\text { Receptive } \\
\text { Adult/Peer Balance }\end{array}$ & \begin{tabular}{|l|} 
Linguistic \\
Expressive \\
Peer
\end{tabular} & $\begin{array}{l}\text { Low } \\
\text { Low } \\
\text { Moderate }\end{array}$ \\
\hline 20 & $\begin{array}{l}\text { Linguistic/Math/Spatial Bal. } \\
\text { Receptive/Expressive } \\
\text { Balance } \\
\text { Peer }\end{array}$ & $\begin{array}{l}\text { Math } \\
\text { Receptive } \\
\text { Self/Adult Balance }\end{array}$ & $\begin{array}{l}\text { Low } \\
\text { Moderate } \\
\text { Low }\end{array}$ \\
\hline
\end{tabular}


teacher perceptions in one category did not necessarily mean mismatch or match in all three areas, although there appeared to be some degree of correlation at either end of the scale - some children well known or "well read" across the board, and others seemingly not so well known. On the whole, however, the individual configurations of students' preferences and teachers' perceptions seemed a bit like snowflakes - no two exactly alike.

Nevertheless, attempts to classify and analyze the matches and mismatches between teachers and students produced some interesting trends (see Table IX). In general, there was a higher level of agreement between students' expressed preferences and teachers' perceptions in the areas of learning methods and modes of social orientation than in preferred classroom activities. This might be explained by the fact that social and learning behavior are more easily and consistently observed than subject area preference in many cases. It was easy to observe in Mrs. Johnstone's class, for instance, that Richard really did prefer to work on his own, while Jane and Riva delighted in one another's company as they worked on Excursions projects. In Ms. Parachinni's class, Maggie and Nora demonstrated such receptive learning behaviors as listening, watching, reading, and operating mentally to solve problems and design inventions throughout the entire Excursions unit. It was also easy to pick out a few students in each class who had particularly strong subject area preferences: Martin, Larry, and Vicki were great at any kind of spatial work; Anita, Jared, and Nick loved every math problem we ever did; Adele's and Spencer's written responses to assigned questions and prompts always went on for pages. And, in fact, the table above shows some instances of high agreement between students and teachers in the area of classroom activities when students' preferences were very strong or very balanced among linguistic, mathematical, and spatial pursuits. Students whose 
TABLE IX

\section{SUMMARY OF AGREEMENT LEVELS BETWEEN STUDENTS AND TEACHERS}

\begin{tabular}{|c|c|c|}
\hline & $\begin{array}{l}\text { Johnstone - Levels of } \\
\text { Agreement }\end{array}$ & Parachinni - Levels of Agreement \\
\hline \multirow[t]{3}{*}{$\begin{array}{l}\text { Classroom } \\
\text { Activities }\end{array}$} & $\begin{array}{l}\text { High Agreement - } 6 \text { cases } \\
\text { (3 spatial, } 1 \text { math, } 2 \text { three-way bal- } \\
\text { anced) }\end{array}$ & $\begin{array}{l}\text { High Agreement - } 6 \text { cases } \\
\text { (4 linguistic, } 1 \text { spatial, } 1 \text { balanced) }\end{array}$ \\
\hline & $\begin{array}{l}\text { Moderate Agreement - } 5 \text { cases } \\
\text { ( } 1 \text { math, } 4 \text { two-way balanced }{ }^{6} \text { ) }\end{array}$ & $\begin{array}{l}\text { Moderate Agreement }-10 \text { cases } \\
\text { (1 linguistic, } 1 \text { spatial, } 6 \text { two-way bal- } \\
\text { anced, } 2 \text { three-way balanced) }\end{array}$ \\
\hline & $\begin{array}{l}\text { Low Agreement - } 6 \text { cases } \\
(1 \text { linguistic, } 1 \text { math, } 1 \text { spatial, } 2 \text { two- } \\
\text { way balance, } 1 \text { three-way balanced })\end{array}$ & $\begin{array}{l}\text { Low Agreement - } 4 \text { cases } \\
\text { (1 math, } 1 \text { spatial, } 1 \text { two-way balanced, } \\
1 \text { three-way balanced) }\end{array}$ \\
\hline \multirow[t]{3}{*}{$\begin{array}{l}\text { Methods of } \\
\text { Learning }\end{array}$} & $\begin{array}{l}\text { High Agreement - } 14 \text { cases } \\
\text { (13 expressive, } 1 \text { receptive/expressive } \\
\text { balance) }\end{array}$ & $\begin{array}{l}\text { High Agreement - } 10 \text { cases } \\
\text { ( } 8 \text { expressive, } 1 \text { receptive, } 1 \text { expres- } \\
\text { sive/receptive balance) }\end{array}$ \\
\hline & $\begin{array}{l}\text { Moderate Agreement - } 2 \text { cases } \\
\text { ( } 2 \text { expressive) }\end{array}$ & $\begin{array}{l}\text { Moderate Agreement - } 7 \text { cases } \\
\text { ( } 2 \text { expressive, } 1 \text { receptive, } 4 \text { recep- } \\
\text { tive/expressive balance) }\end{array}$ \\
\hline & $\begin{array}{l}\text { Low Agreement - } 1 \text { case } \\
\text { (1 receptive) }\end{array}$ & $\begin{array}{l}\text { Low Agreement - } 3 \text { cases } \\
\text { ( } 3 \text { receptive) }\end{array}$ \\
\hline \multirow[t]{3}{*}{$\begin{array}{l}\text { Modes of } \\
\text { Social } \\
\text { Orientation }\end{array}$} & $\begin{array}{l}\text { High Agreement }-5 \text { cases } \\
(3 \text { self, } 1 \text { peer, } 1 \text { peer } / \text { adult }\end{array}$ & $\begin{array}{l}\text { High Agreement - } 10 \text { cases } \\
(3 \text { self, } 5 \text { peer, } 2 \text { self } / \text { peer })\end{array}$ \\
\hline & $\begin{array}{l}\text { Moderate Agreement - } 6 \text { cases } \\
\text { ( } 1 \text { peer, } 1 \text { adult, } 2 \text { self-peer, } 2 \\
\text { self/peer /adult) }\end{array}$ & $\begin{array}{l}\text { Moderate Agreement - } 5 \text { cases } \\
\text { ( } 3 \text { self } / \text { peer, } 2 \text { peer } / \text { adult) }\end{array}$ \\
\hline & $\begin{array}{l}\text { Low Agreement - } 6 \text { cases } \\
\text { ( } 3 \text { self, } 1 \text { peer, } 1 \text { self } / \text { peer, } 1 \\
\text { self } / \text { peer } / \text { adult) }\end{array}$ & $\begin{array}{l}\text { Low agreement }-5 \text { cases } \\
\text { ( } 1 \text { self, } 3 \text { peer) }\end{array}$ \\
\hline
\end{tabular}

${ }^{6}$ The profiles noted in this table reflect the students' expressed preferences. 
preferences were less intense, or balanced between two types of activity tended to receive lower levels of agreement from teachers. Then there is the intriguing issue of complete mismatch. If we assume that Mrs. Johnstone's and Ms. Parachinni's responses to the Classroom Preferences Questionnaire were based on nearly a year's worth of interaction with student, can it be inferred that strong expressed preferences were demonstrated in children's classroom performance? What about students for whom there was very little preference/perception match? Did they mark their questionnaires on the basis of wishful thinking - a desire to be good at a particular activity rather than an actual preference - or an enthusiasm that was all but invisible to adults? Ultimately, this sort of analysis necessitates an examination of students' work, or, in on-going classroom situations, further observation and inquiry directed particularly toward children for whom little match is found.

\section{EXAMINING THE WORK OF “STRONG PREFERENCE" STUDENTS}

Each intelligence has its own ordering mechanisms, and the way that an intelligence performs its ordering reflects its own principles and its own preferred media. Gardner, 1983

If, as Gardner has suggested, children operate from their own particular configurations of intelligence, and if student's expressed preferences for certain types of activities and styles of learning are demonstrated in actual practice, we should expect to see differences in their work that reflect distinct profiles of intelligence. To explore this proposition, I examined the Excursions work of four children in Ms. Parachinni's class. This group included three children who expressed stronger preference for linguistic, mathematical, or spatial activity than any of their classmates, as well as one child who expressed equal preference for all three types of activity. These youngsters were the "extremes'. Anita's questionnaire 
allocated 9 preference points to linguistic activities, 4 to math and 2 to spatial pursuits. Micah's questionnaire showed a much more balanced profile, with 5 points given to language, 6 to math, and 4 to spatial activities, but also represented the strongest preference for math in the class. Martin's responses resulted in 1 point given to language, 4 to math, and 10 to spatial activities, while April's questionnaire allocated 5 points to each type of activity ${ }^{7}$. An investigation of their work over a range of three different tasks, one linguistic, one mathematical, and one spatial, revealed some interesting differences.

The first work sample I examined was a written evaluation of "The Popcorn Party", an Excursions unit the class had just completed. In thinking back over the unit, children were asked to respond to the following questions:

1. What were your favorite parts of the unit?

2. What was hard?

3. What was easy?

4. How did you use math?

5. Would you recommend this unit to another class? Why?

6. What did you learn?

In contrasting the four samples, I looked at form, style, mechanics, the children's main concerns, and their sense of audience.

Anita's replies (Figure 10) are complete and conversational - you can almost hear her talking. Her spelling is reasonably accurate and her use of capitalization and such conventions as periods, commas, and ampersands is fairly sophisti-

7 Parenthetically, Ms. Parachinni's perceptions of these children, as indicated by her questionnaire responses, demonstrated a high level of agreement with April's and Anita's expressed preferences. She was in moderate agreement with Martin, whom she saw as linguistic as well as spatial, and low agreement with Micah, whom she viewed as having almost exclusively mathematical preferences. 
cated. Many of her responses revolve around people: it was fun to figure out how many guests to invite, but hard to decide whom to invite. In the end, a party for 112 people was fun, but lots of work.

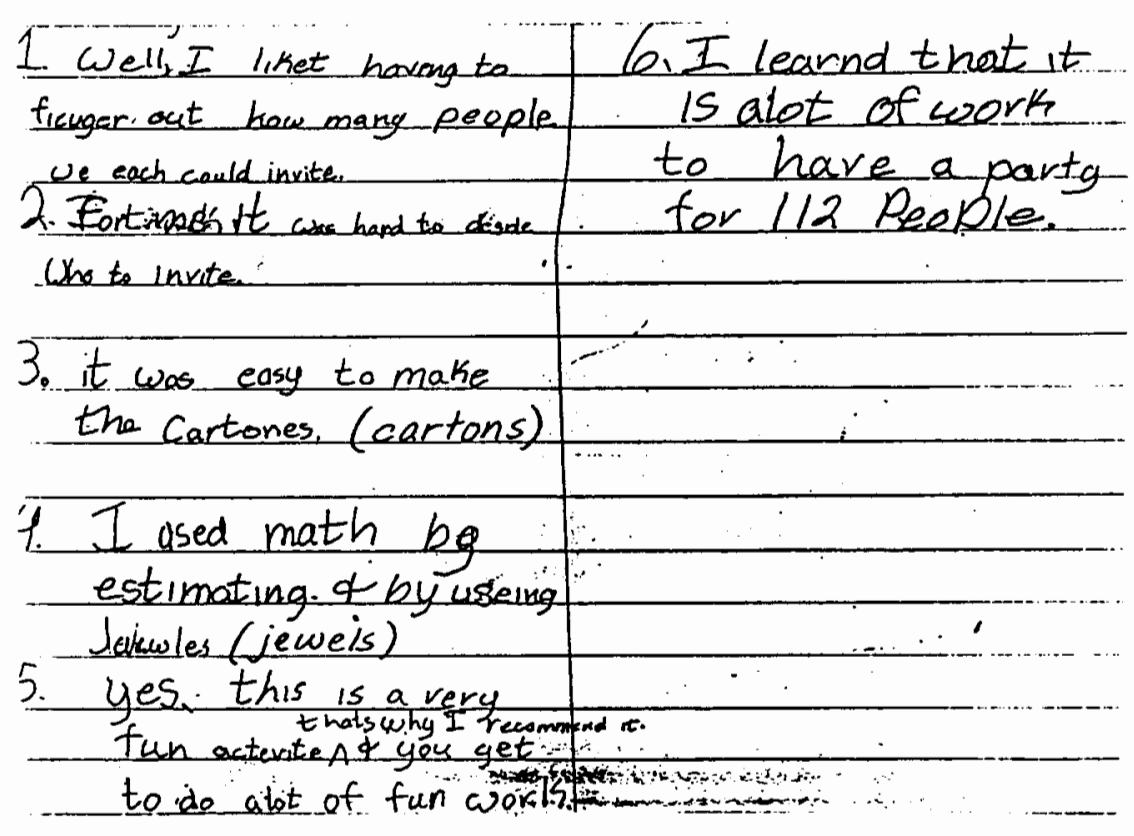

Figure 10. Anita's evaluation of the Popcorn Party.

Micah (Figure 11) has responded in a very straightforward way - each question is answered directly, with a minimum of words, and the effect is much less conversational. $\mathrm{He}$, too, uses capitals and periods, but not always conventionally. People do not enter his considerations. It was hard to make the cups, easy to eat the popcorn, and educational to put on a party.

Martin's response (Figure 12), which is in narrative instead of short answer form, expresses relief at completing the project because he "was tired of talking about it". In a manner reminiscent of Gardner's "patterners" (1975), Martin attends to the world of objects, rather than people, expressing admiration for my mini-tape recorder, and listing some of the mathematical tasks he and his class 


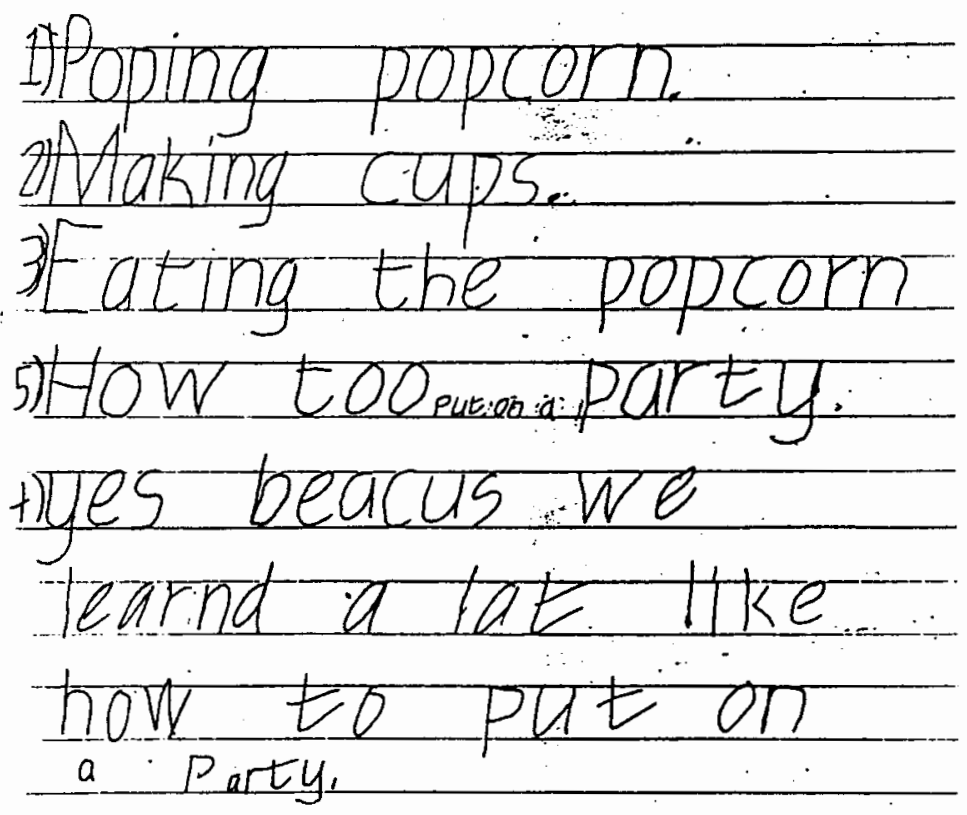

Figure 11. Micah's evaluation of the Popcorn Party.

mates had to perform to make the party possible. Like Anita, he uses punctuation and spelling in a fairly sophisticated manner.

My Fovret lart was the party cues I wabted. to yet it over with! cues I was tierd of Talking a bout it. 3ui I Liked the mini tape recorder. We had to find out How many Baches we neded, and that was twanty four, and one half 4p e kweld = five Bades, then we neded to tind out how many tabelswe neded, and then we had the partg a after afwew prodles. I lernd that one hundred twelve peopte

Figure 12. Martin's evaluation of the Popcorn Party.

April's response (Figure 13), like Anita's and Micah's, is in the form of short answers, although her remarks do not seem to correspond to the numbers on the questions. Of the four, her spelling and use of conventions are the least sophisticated, but her paper is tidy, easy to read, and nicely illustrated. Her concerns seem to revolve mostly around the mechanics of the project (cups, popcorn, 
brainstorming), although math did prove useful for figuring out how many guests to invite.

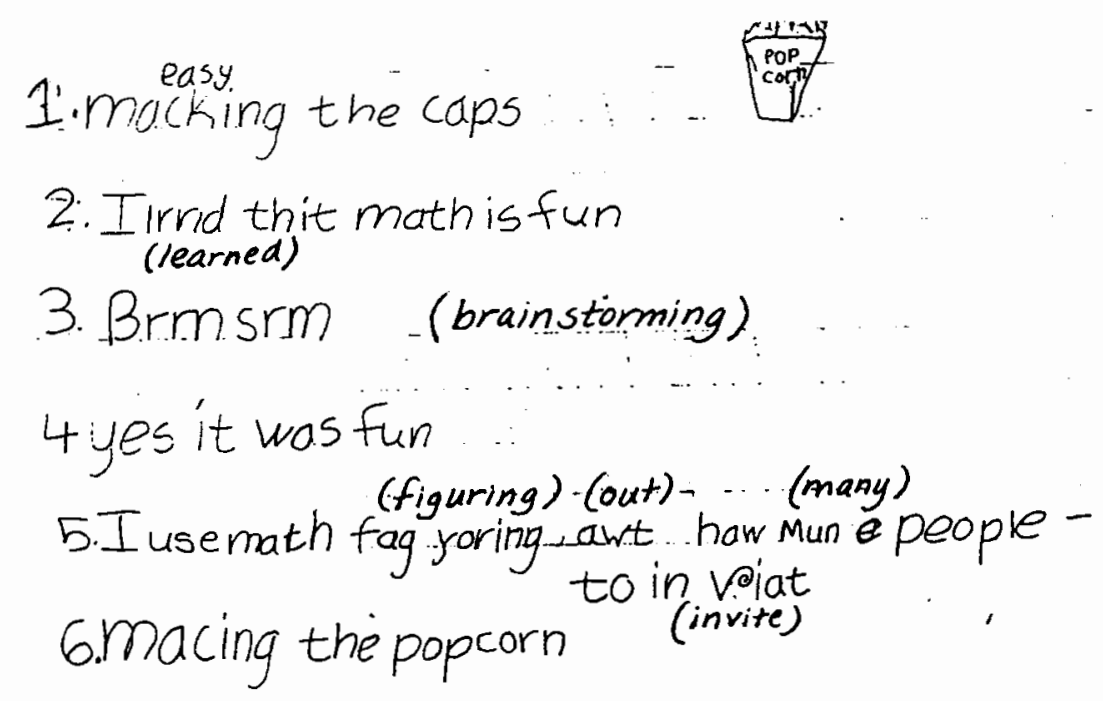

Figure 13. April's evaluation of the Popcorn Party.

The next task I looked at was a math problem in which the children were to work in partners to figure out how many guests each person in their class could invite to the popcorn party, holding the total as close to 100 as possible. They were allowed to use anything in the room, including calculators, to solve the problem, and were to write an explanation of their findings when they were done. This was a challenging problem, and some children experienced considerable difficulty with the idea that the total had to include class members as well as guests. In considering students' responses, I looked at their problem-solving strategies and the extent to which writing seemed a useful tool in terms of clarifying their thinking.

Anita's response (Figure 14) is a narrative description of the techniques she and her partner used to solve the problem. 


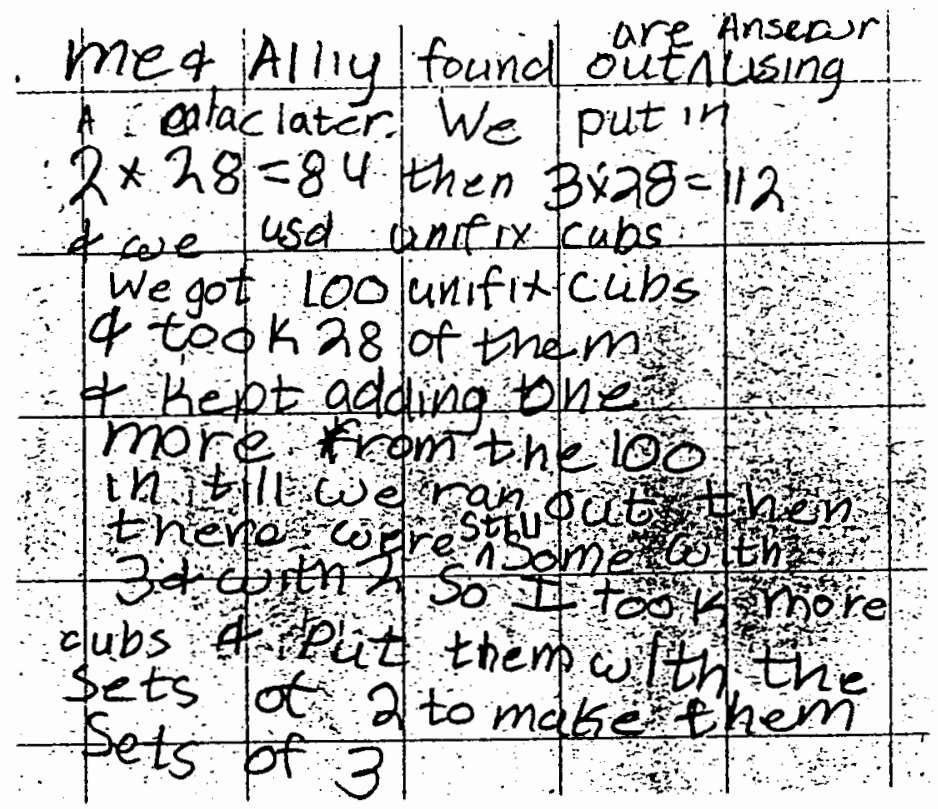

Figure 14. Anita's response to a math problem.

As in her unit evaluation, her efforts are directed at communicating clearly with the reader by using complete sentences in a conversational manner. I't's not clear whether or not she and her partner understood the results they got by using a calculator (incorrect, as reported), but her description of their operations with unifix cubes is quite lucid although she doesn't report their final solution.

Micah's explanation, by contrast, is very short and to the point (Figure 15).

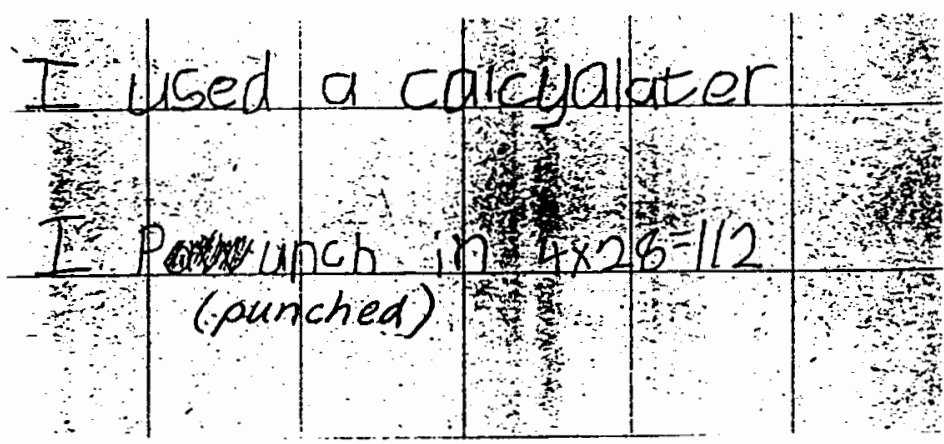

Figure 15. Micah's response to a math problem.

He used a calculator to get the answer, which was 112, and that was that. There is 
no indication in his written explanation of how he knew which numbers to enter, but 28 represents the number of children in the class, and my guess is that 4 was a good estimate on his part, resulting in a number that was as close to 100 as possible. This was a short and easy problem for Micah, and he did not feel compelled to work it out with manipulatives or explain his thinking, which was quite obvious to him, in great detail.

Martin's response to the problem was to begin sketching as his partner talked and worked things through with beans (Figure 16).

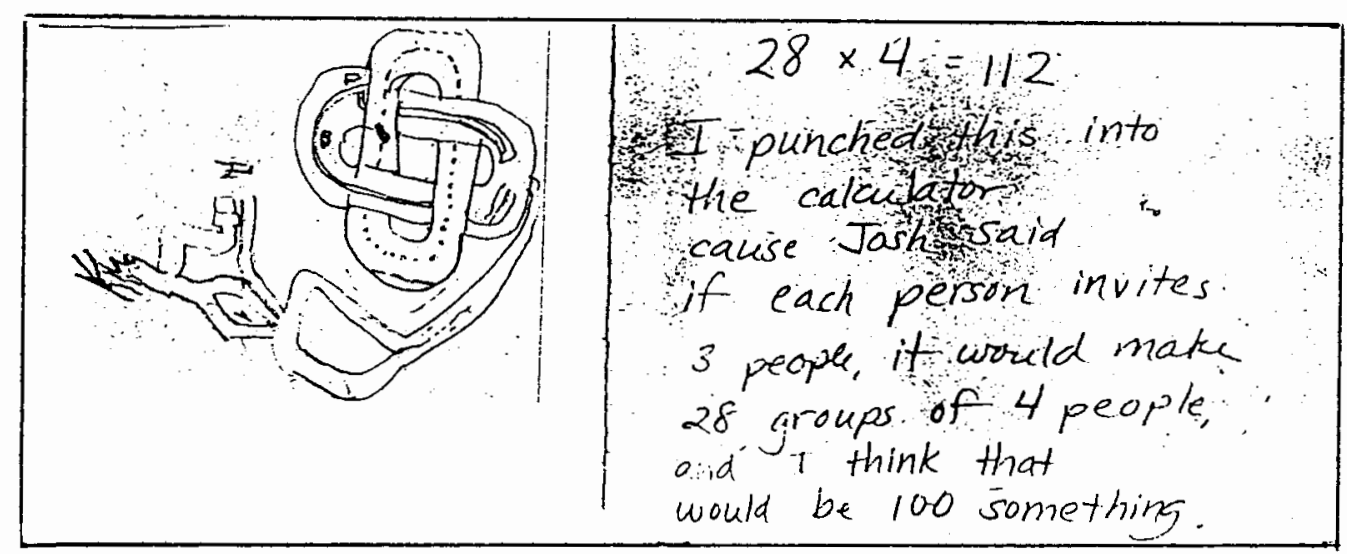

Figure 16. Martin's response to a math problem.

When I came by later, his doodle had become a rather elaborate racetrack that appeared to have nothing to do with the problem. Martin did not seem particularly interested in writing a description of his thinking, but when I asked him what he and his partner had discovered, he volunteered a explanation that indicated both an understanding of the problem, and some attempt to solve it mentally as well as with a calculator (see transcription above). He also explained that drawing mazes and tracks while he was working helped him think.

It is interesting to me that April's written response to the problem (see Figure 17 is a balanced use of three different modes, in that it includes numbers, words, 
and pictures, and is presented almost as a diagram, with arrows pointing from the drawings of the cubes to the words, "I used unifix cubes", and the number sentence to its corresponding word sentence. She and her partner did, in fact, punch $28 \times 4$ into the calculator to get an answer of 112, but being unclear about what they'd done or what the numbers meant, had also used 100 unifix cubes, which they set out in groups of three to represent the invited guests. What's not clear is whether or not there was any eventual connection between the numbers and the cubes.

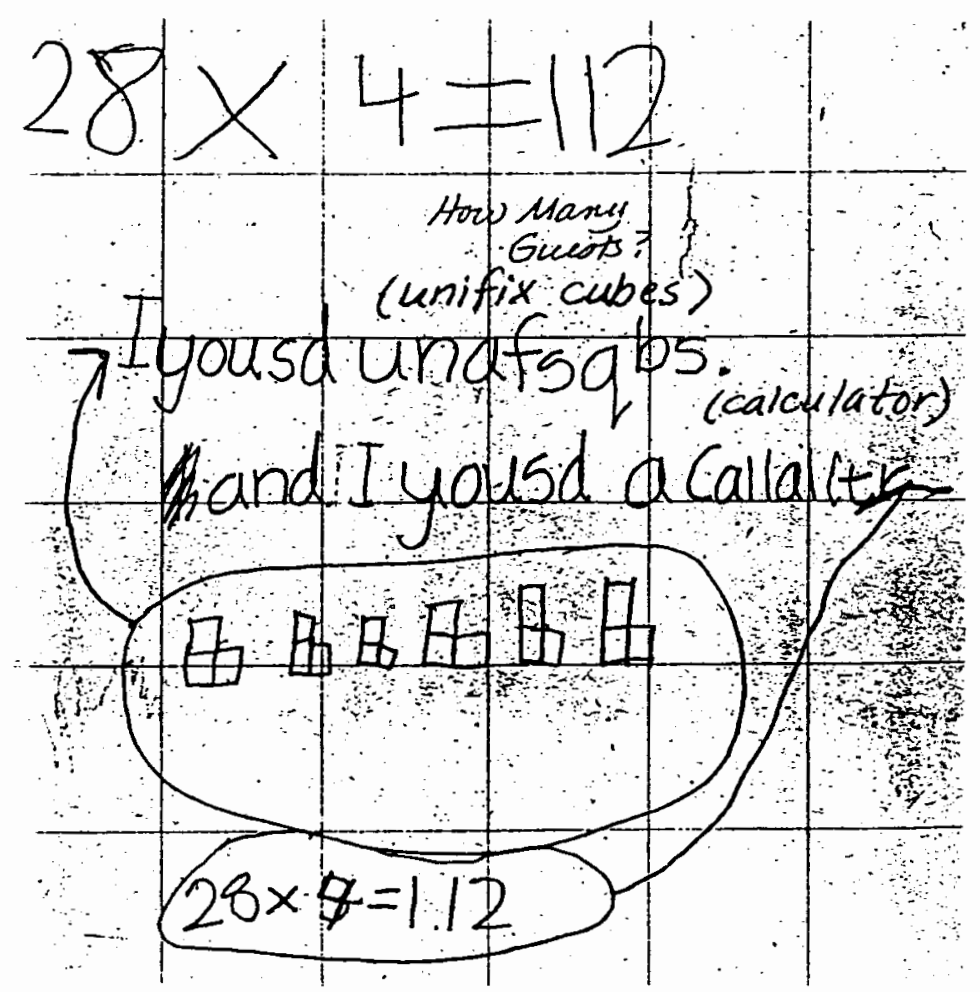

Figure 17. Anita's response to a math problem.

The last task I examined was a spatial problem in which the children were to sketch a design for a container that would hold 16 ounces of popcorn using a single sheet of $81 / 2^{\prime \prime} \times 11^{\prime \prime}$ paper and tape or staples and then actually make it. In contrasting their responses, I looked at both their sketches and the finished 
products, examining the extent to which the product resembled the plan; the degree to which students were able to visualize and then carry out their plans. I was also interested in the considerations that seemed to motivate children. Were they primarily concerned with size, complexity, or beauty; form or function?

Anita's sketch (Figure 18) shows a side view of a folded origami basket she'd learned to make at home. Paper-folding was one of her specialties, and she figured the basket she could make from an $81 / 2^{\prime \prime} \times 11^{\prime \prime}$ sheet of paper would be about the right size for 16 ounces of popcorn.

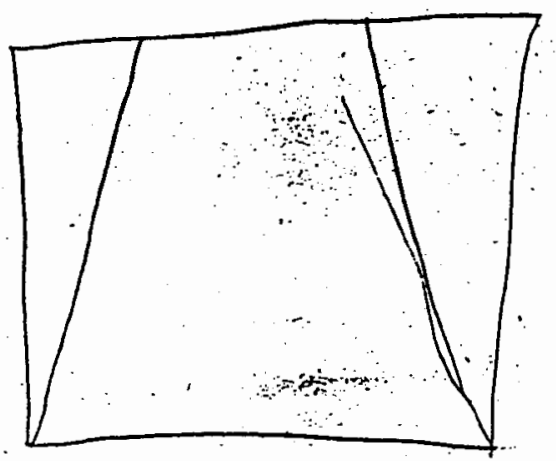

Figure 18. Anita's popcorn container plan.

Her finished container looked exactly like her sketch, although the sides had to be pulled out a bit to accommodate the required amount of popcorn.

Micah sketched out two plans (Figure 19) but wound up making the cylinder because it was easier. Foremost in his mind as he sketched and created the container was its size: he knew it had to be big to accommodate that much popcorn, and, in fact, his completed cone was one of the more efficient designs in class, in that it used up very little paper in folds or overlaps.

Martin, on the other hand, was far more concerned with complexity than size in his design. Somewhere, he explained, he'd seen a popcorn container that had some sort of spout at the top and a slot at the bottom for getting at the popcorn. 


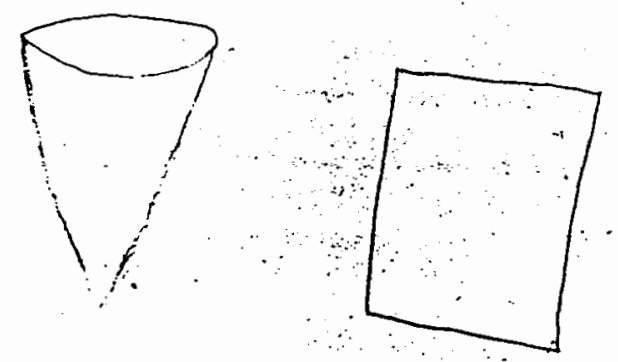

Figure 19. Micah's popcorn container plan.

His sketch (Figure 20) shows the container he intended to make from several angles, including a top view (the small double circle at the lower left). He spent a great deal of time constructing a cylindrical container with circular top and bottom, a spout at the top, and an "eating slot" at the bottom. His finished product looked a great deal like his original sketches, complete with a small " 4 " on the side. He was fully aware that his container would not hold enough popcorn, but also totally unconcerned.

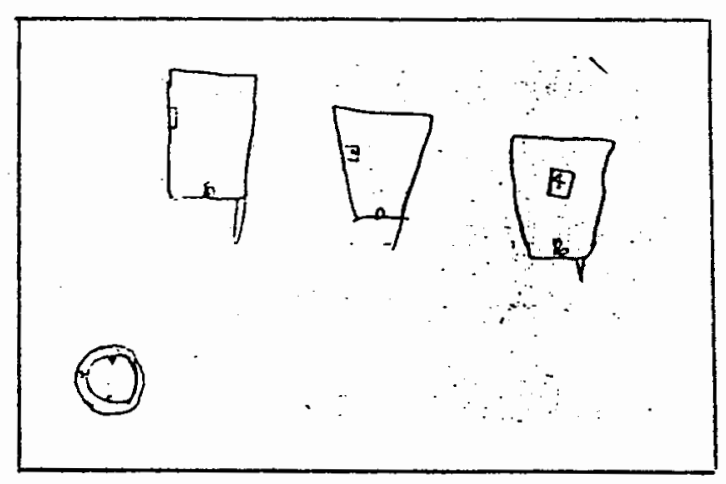

Figure 20. Martin's popcorn container plan.

April began by sketching a sort of paper bag, but then erased it and drew several other shapes, seeming to experiment with several possibilities (Figure 21). In the end, she wasn't sure what to do and worked with Anita, as did several other girls, to create an origami basket. Although her design wasn't original, she realized that it wouldn't hold enough popcorn and pulled out one of the corners to 
create more room when it was time to test the containers' capacities.
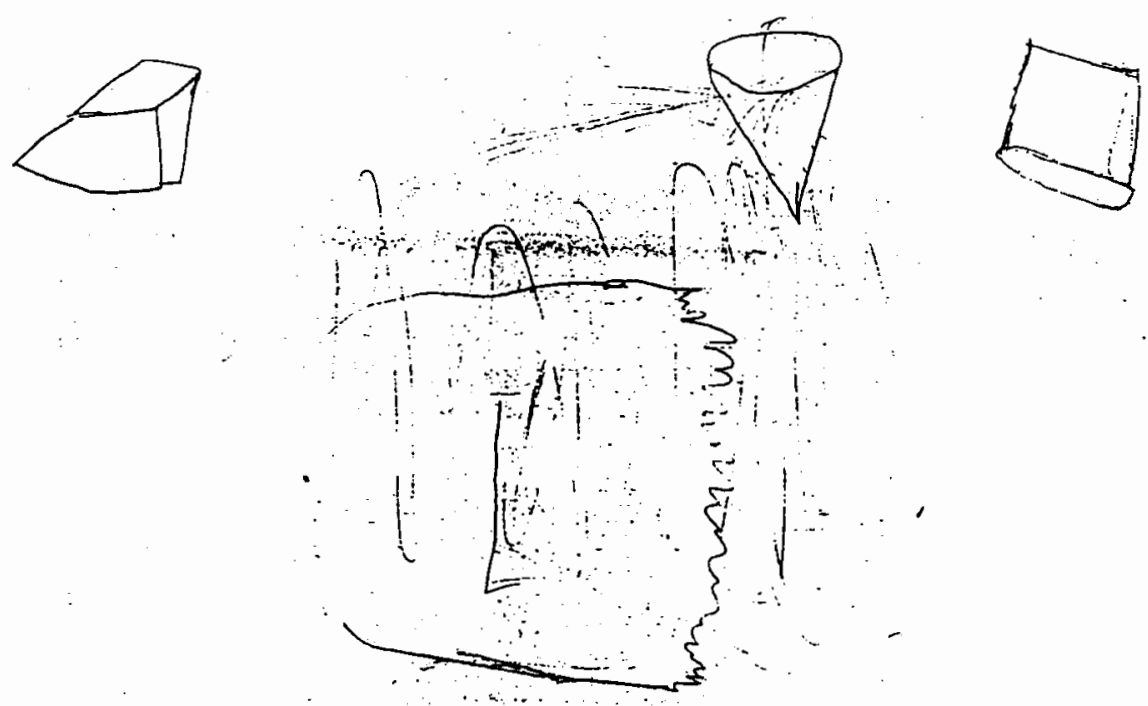

Figure 21. April's popcorn container plan.

\section{DISCUSSION}

In examining the work of these four students, it seems clear to me that their expressed preferences are, in fact, demonstrated in their classroom work. Anita, who expresses high preference for linguistic activities does use words effectively. Her writing is clear, detailed, mechanically sophisticated, and highly conversational. Like Gardner's "verbalizers" (1975), her energies are devoted toward effective communication with others and toward dramatic sharing of her experiences. Judging from her detailed written and verbal explanations of math problems, I believe Anna also uses word to make sense of other domains - talking and writing her way through to solutions.

It appears that Micah's and Martin's worlds are considerably less verbal. Micah needs few words to explain what, for him, are obvious chains of reasoning with numbers or logical propositions, while Martin says much with pictures, sketches, and diagrams. Both boys resemble Gardner's "patterners" (1975) in 
their interest in the configurational uses of materials - the making of patterns, structures, and orders. Their concerns appear to be more centered in the world of objects than the world of people. Martin's obvious ability to manipulate visual experience, moving from remembered popcorn container, to sketch, to creation of a new and complex three-dimensional object marks him as a person with high spatial intelligence in Gardner's framework.

April is harder to pinpoint. As a child who expresses equal preference for linguistic, mathematical, and spatial activities, she appears to use elements of all three. This renders her products less "spectacular" in any of the three domains, but may allow her a valuable sort of flexibility to use one tool or another - words, numbers, or pictures - as the situation demands. It is interesting, but no longer surprising, to note that Ms. Parachinni's perceptions of these four children matched their expressed preferences. As a perceptive classroom practitioner, who had nearly a year to observe their strengths and proclivities, Ms. Parachinni surely noticed the sorts of performance and behavior noted above on a daily basis. There were some students, though, whose expressed preferences for certain types of activities differed considerably from their teachers' perceptions. It is to them that I now turn my attention.

\section{EXAMINING THE WORK OF STUDENTS WHOSE EXPRESSED PREFERENCES DON'T MATCH TEACHERS' PERCEPTIONS}

As outlined in Chapter 4, I selected the work of four pairs of children, two from each class for further study. Both children in each pair expressed strong preference for the same type of classroom activity - one pair, linguistic; one pair, mathematical; and two pairs, spatial. The difference between the children in each pair was the degree to which their teachers' perceptions of their preferences 
agreed with their own expressed preferences, agreement being high for one child and low for the other. My purpose for this investigation was to get at some of the issues underlying mismatch between student expression and teacher perception.

The first pair I looked at was Becky and Spencer, both of whom showed strong preference for linguistic activity on the Classroom Preferences

Questionnaire. Ms. Parachinni indicated a high level of agreement with Becky, but saw Spencer as someone who had much stronger interest in the areas of math and spatial activity. I was a bit perplexed when I first examined samples of their written work (Figure 22) because they both looked fairly proficient with words.

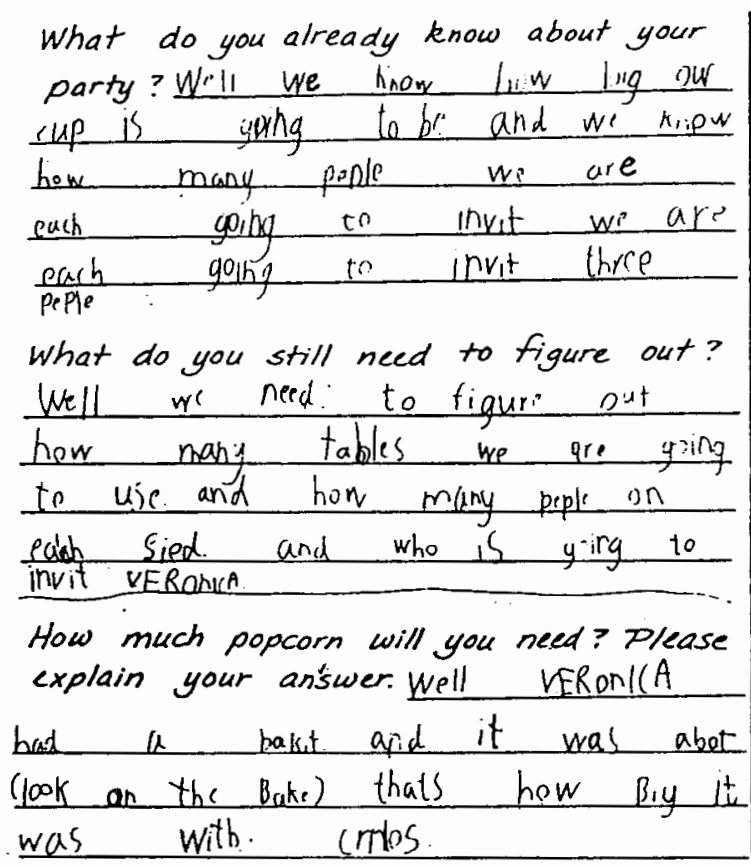

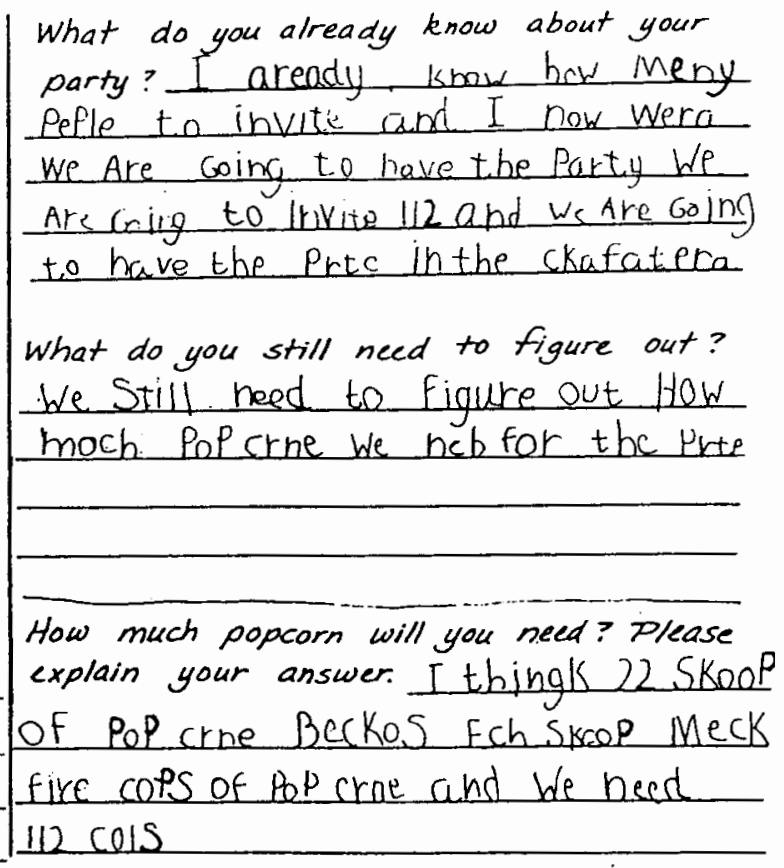

Figure 22. A comparison of Becky's and Spencer's linguistic work.

Upon closer reading, however, it became apparent that Becky had the sort of chattiness and concern for the world of people that seems to characterize linguistic learners, wondering who was going to invite Veronica, and estimating the amount of needed popcorn on the basis of a basket of kernels Ms. Parachinni had showed them. Spencer, on the other hand, had taken an extraordinarily mathe- 
matical approach to the last question, calculating the amount of popcorn needed almost exactly. Examination of another sample of Spencer's mathematical work revealed a similar bent for highly logical reasoning, expressed in a most detailed and verbal manner, despite the arithmetical errors (Figure 23).
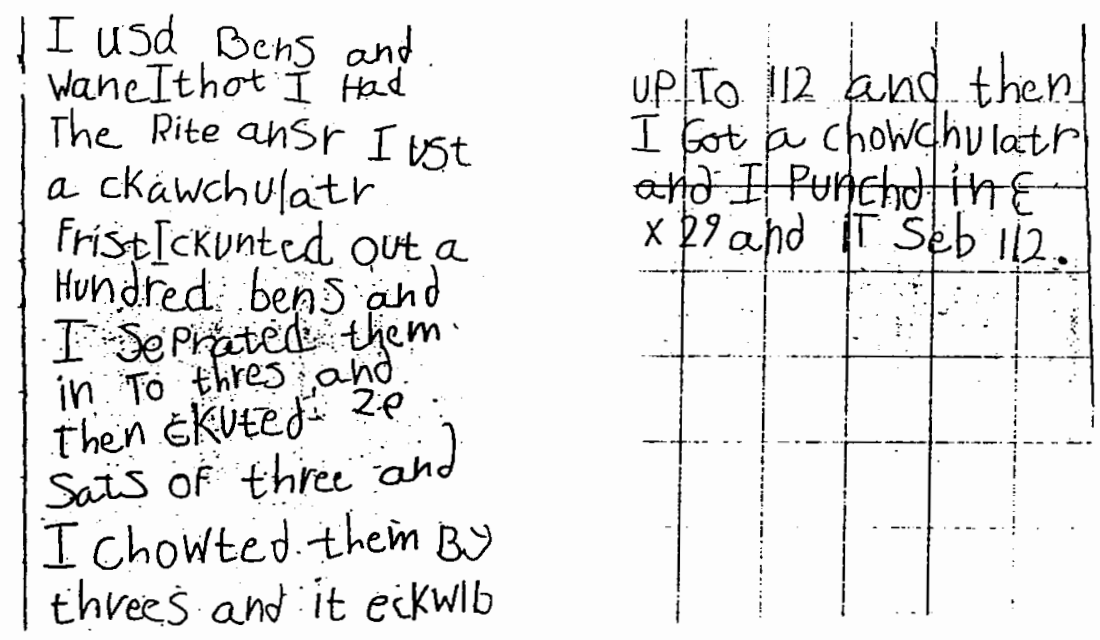

Figure 23. Sample of Spencer's math work. (I used beans and when I thought I had the right answer, I used a calculator. First I counted out a hundred beans and I separated them into threes and and then scooted 29 sets of three and I counted them bythrees and it equaled up to 112 and then I got a calculator and I punched in $3 \times 29$ and it said 112.)

Could it be, I wondered, that children with strong abilities in several areas didn't have adequate chance to express their preferences on the questionnaire? It was interesting to know that Spencer identified such strong preferences for linguistic activities, when it appeared that he was equally adept at mathematics.

A similar situation emerged in looking at the work of two students in Mrs. Johnstone's class. Vicki and Richard both expressed strong preference for spatial activity, while Mrs. Johnstone saw Vicki as someone with very strong preferences in the area of language. In looking at their work samples, I found that both youngsters took a rather map-like approach to drawing their vision of the finished village (Figures 24 and 25). 


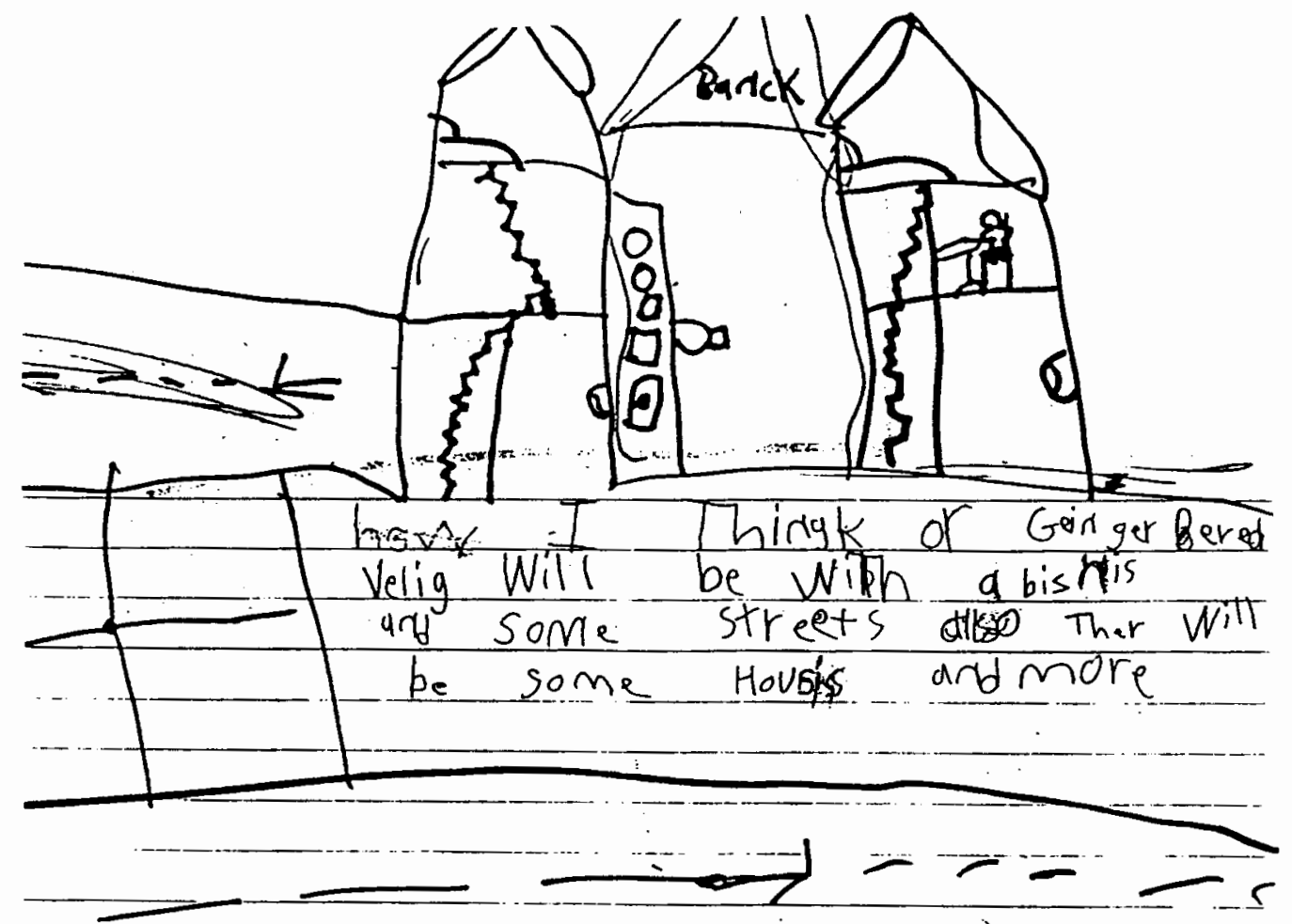

Figure 24. Richard's drawing of the imagined village.
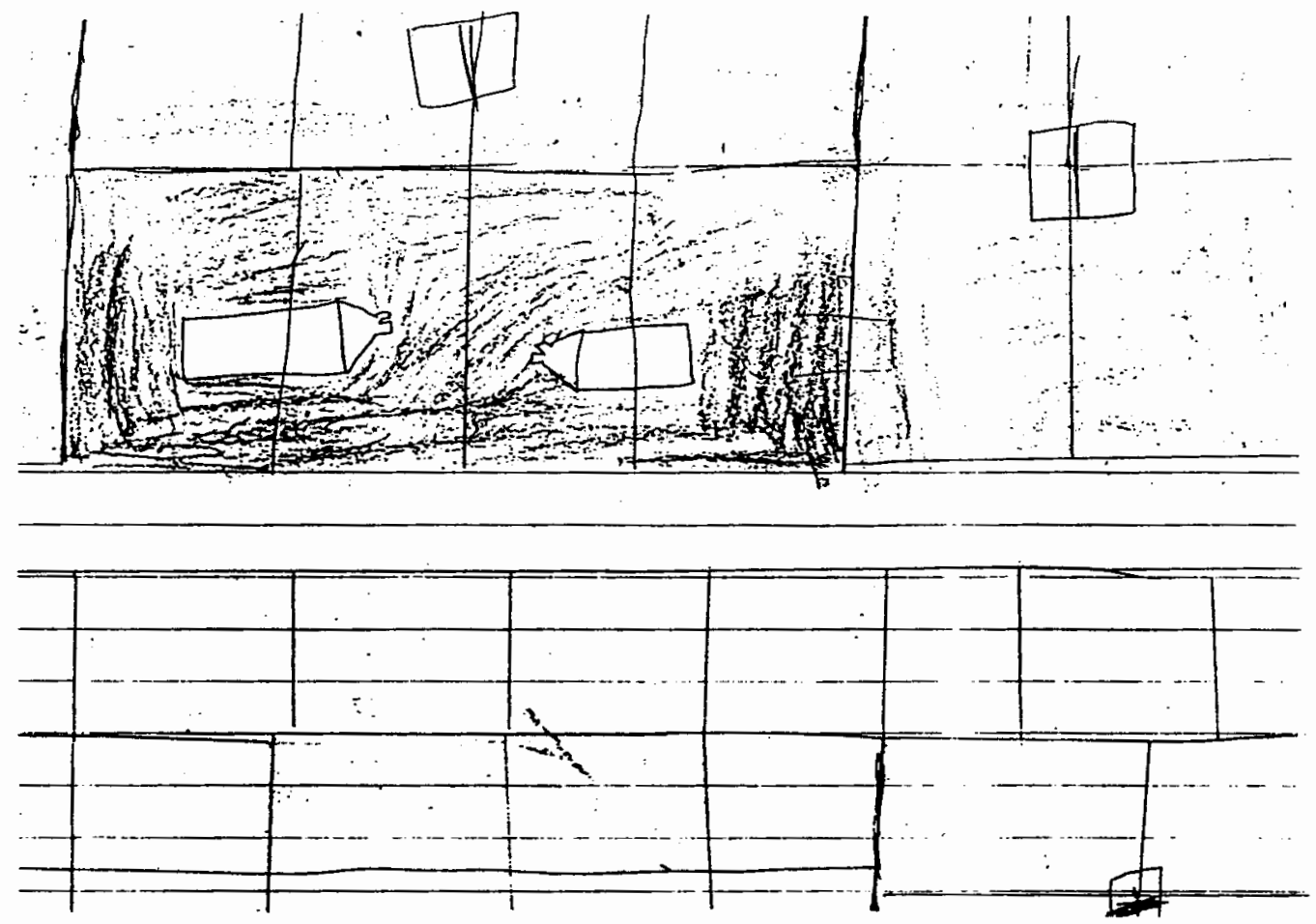

Figure 25. Vicki's drawing of the imagined village. 
Vicki, in particular imagined the village in terms of a grid, even the buildings laying flat, while Richard drew a combination picture-map, showing cut-away side views of the buildings. Both responses to the task seemed highly spatial. In looking at other samples of Vicky's work, I came across a plan she'd drawn for her milk carton house, which she followed exactly - every window and every door set exactly as planned, with no deviation, a bit like Martin carrying out his plan for the popcorn container. Looking at a sample of her writing showed some of the chattiness found in Anita's and Becky's work, but not nearly the fluency (see Figure 26).

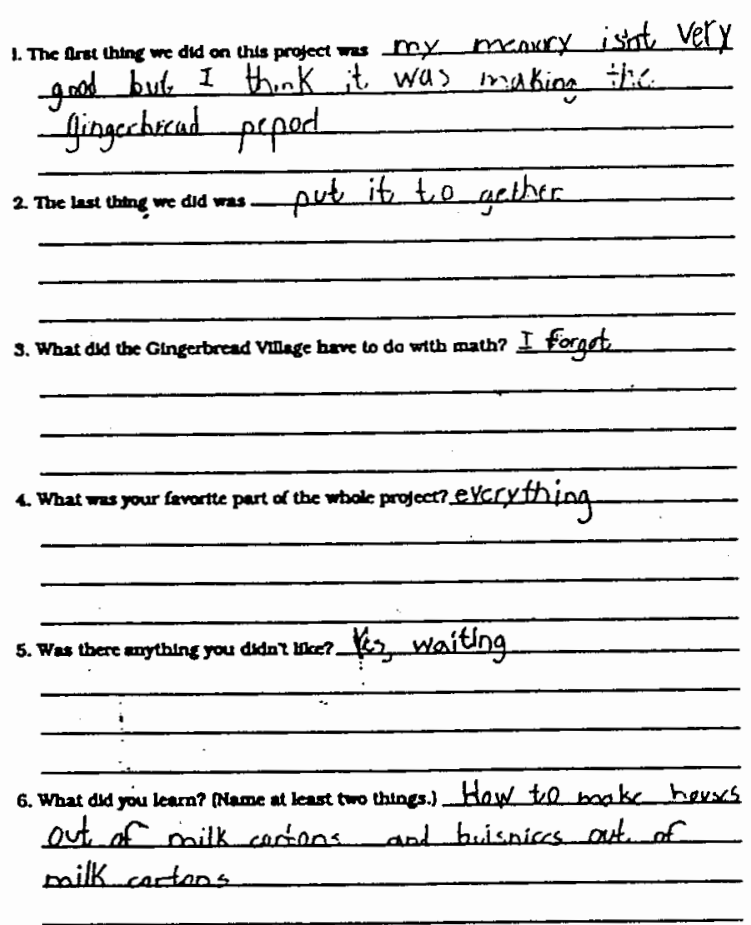

Figure 26. Vicki's evaluation of the gingerbread village project.

The quality of her spelling, punctuation, and hand-writing was better than nearly anyone else's in her class however, and I could understand why Mrs. Johnstone might have perceived her to have strong linguistic preferences. How important, then, to know about Vicki's expressed preferences for math and spatial work. 
The other two pairs I investigated seemed more illustrative of the "halo effect" seen in nearly all self-report instruments. Jared and Jay both expressed strong preference for mathematical activity, while Mrs. Johnstone saw Jay's interests as almost exclusively spatial. In examining work samples and anecdotal records on both boys, I found ample evidence that math was much easier for Jared (see Figures 27 and 28), while Jay positively shone at spatial tasks.
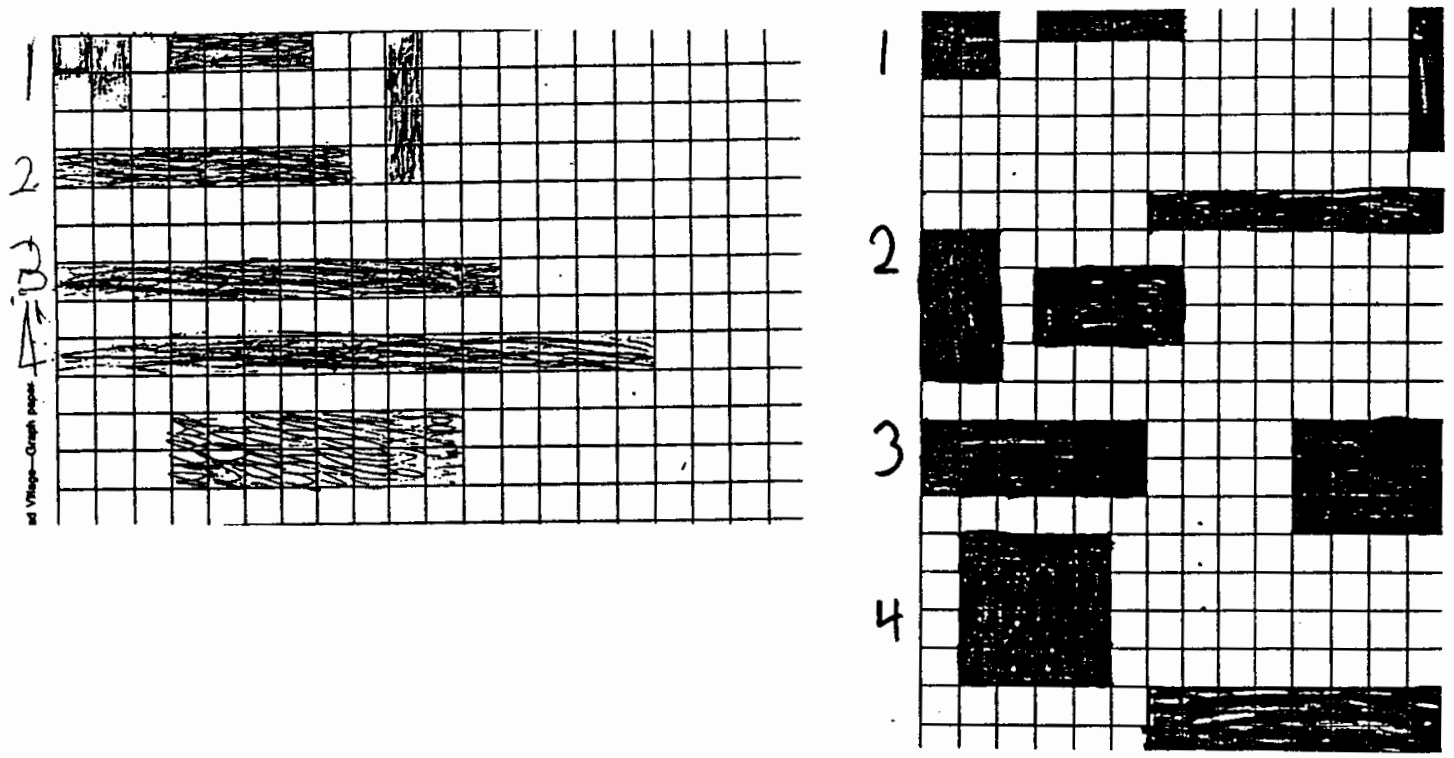

Figure 27. A comparison of Jay's and Jared's math work.

The paper on the left is Jay's, the one, on the right is Jared's. The assignment was to create and record as many different rectangles as possible, using 4, 8, 12, and 16 squares. The numbers $1,2,3$, and 4 alongside each paper refer to the number of squares needed for a one-carton building, a two-carton building, a three-carton building, and so on. Although both boys enjoyed the task, Jared had an easier time with it, and got much further in his investigations. Computation was particularly difficult for Jay, and very easy for Jared, who was often able to solve such problems as $15+15+27$ mentally. 


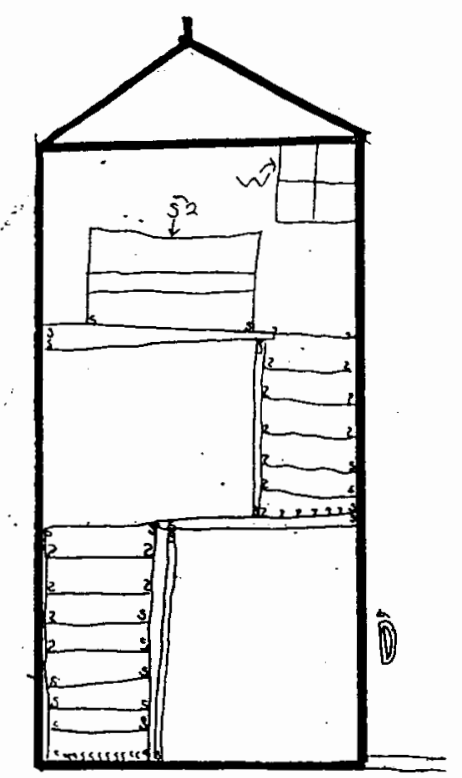

Figure 28. Jay's milk carton house plan.

Jay, on the other hand, was extremely adept spatially. He drew and labeled this plan and followed it with the precision of a draftsman in building his house.

Like Jared and Jay, Eden and James both expressed strong preference for spatial work, but Ms. Parachinni saw Eden as someone much more inclined to linguistic activity. Neither of their plans for popcorn containers (Figures 29 and 30) were as complex as Martin's, but James indicated his intention to make his threedimensional in an intriguing manner and actually managed to construct a cylindrical product, while Eden created a flat envelope.

Despite the fact that Eden's finished container looked rather ordinary, I would have been interested to know about her preference for spatial work early on, because she exhibited a great deal of reluctance to perform many other tasks in class, including activities that involved reading or writing (see Figure 31). 

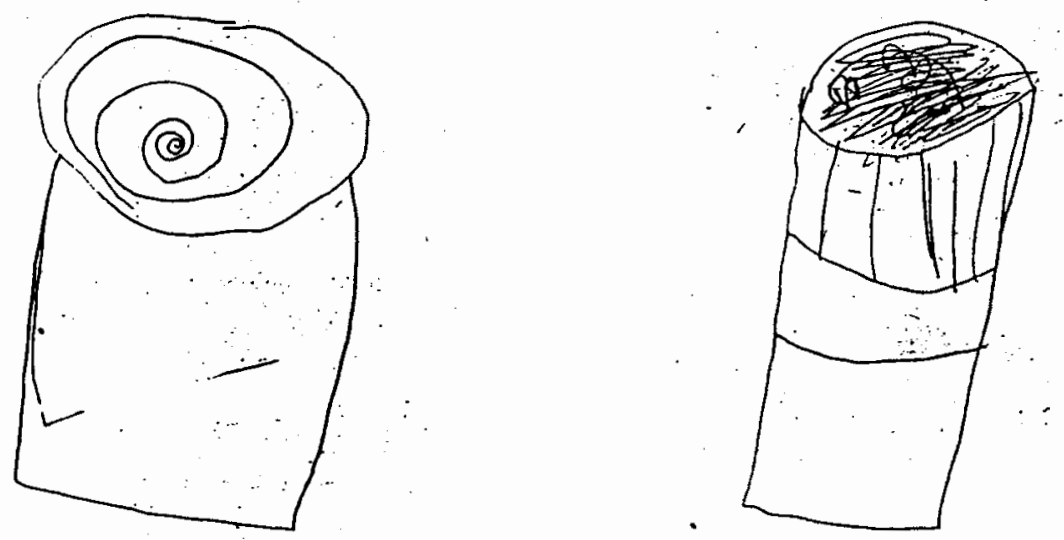

Figure 29. James' container plan. Figure 30. Eden's container plan

1. What do you already know about your

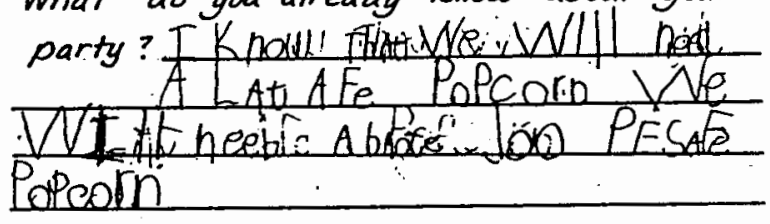

2. What do you still need to figure. out?

3. How much popcorn will you need? Dlease explain your answer.

Figure 31. Eden's response to a questionnaire about the popcorn party.

\section{DISCUSSION}

My investigations of high- and low-agreement pairs have shown that while the Classroom Preferences Questionnaire probably allows some children to profile themselves rather accurately, it does not work so for all students. The Questionnaire is surely as subject to "halo effects" as any other self-report instru- 
ment; children may well indicate preferences on the basis of longing to be good at something they're not, or desire to look good in the eyes of the teacher. Others may think they're "supposed" to prefer math to art, or working with a partner to working alone. In addition, it may be that the Questionnaire is not complex enough to accurately register more than one or two intelligence strengths. Although many students indicated preference for a balance of two or three activities, agreement between teachers and students seemed to be highest among those who expressed and demonstrated extremely high preference for one type of class activity. Another factor worth considering is that many classroom tasks require a combination of intelligence skills. It is helpful indeed to be verbally competent when solving any but the most mundane math problems. Likewise, spatial skills have much to do with science and mathematics. Children such as Martin who express strong preference for only one type of activity may actually excel, or have the potential to excel at tasks across a number of domains, especially when allowed to use their preferred learning vehicles. Whatever the Classroom Preferences Questionnaire lacks as a diagnostic tool, however, is of little concern to me, for I view its primary virtue as an avenue to discussion and dialogue with students. It is this and other potential uses of the Questionnaire, that I plan to discuss in my closing chapter. 


\section{CHAPTER VI}

\section{CONCLUSIONS AND DISCUSSION}

\section{USING INFORMATION GAINED FROM THE CLASSROOM PREFERENCES QUESTIONNAIRE TO ENHANCE STUDENTS' SELF KNOWLEDGE}

Although the Classroom Preferences Questionnaire might be used to help guide curricular and instructional decisions, as well as focus further observation and inquiry, perhaps its most appropriate use is to promote self-awareness and acceptance of diversity among students and teachers. So many decisions, including what to learn, how to learn, and with whom to learn are normally made by teachers, that students may not even be aware of the spectrum of legitimate possibilities that exist in a classroom. Some may even be unwitting victims of their own preferences, as children who prefer to work alone sometimes suffer under the new pressures imposed by cooperative learning, while those who prefer to draw their stories are sometimes browbeaten by well-meaning teachers who' $\mathrm{d}$ be so much happier with words. For students and teachers alike, then, what a revelation to acknowledge that some people like to figure things out in their head, while others prefer to sketch their ideas on paper; that some people like to work with objects while others prefer to play with words or numbers; that some people like to work on their own ideas, while others would rather develop ideas with a group.

The Classroom Preferences Questionnaire can be used to discuss the fact that there are a variety of classroom activities, approaches to learning, and modes of 
social interaction. Furthermore, once children have indicated their own preferences, the information can be shared by having them score their own responses or by holding informal chats to discuss the results. Students want to know and should know about their strengths and proclivities; the things they're good at and the areas in which they're weaker. Such knowledge is helpful to teachers as well, for while they may not always be able to act on each student's preferences they can acknowledge and respect them with such remarks as, "I know working in groups isn't your favorite way, but you'll be able to work on the next project by yourself if you choose", or "I'm curious to know more about how you solved this math problem. Would you rather use words or pictures to show me?" Awareness of the fact that there are tools other than words and numbers, multiple approaches to learning and solving problems, and possibly intelligences other than linguistic and mathematical is a boon to teachers and students alike.

\section{USING INFORMATION GAINED FROM THE CLASSROOM PREFERENCES QUESTIONNAIRE TO INFLUENCE CURRICULUM DECISIONS}

Although learning style theorists hold fast to the notion that one can diagnose, and then teach to a variety of individual styles, there is general consensus, at least among critics, that such efforts haven't really proved themselves to be of much worth. A meta-analysis by Kavale and Forness concluded that the practice "is ineffective... Although the notion of modality-based instruction remains intuitively appealing, the evidence is not supportive" (Kavale and Forness, 1987). Gardner, too, is aware that such attempts have not met with much success, but suggests that if one adopts the theory of multiple intelligences, "the options for such matches increase: as I have already noted, it is possible that the intelligences can function both as subject matters in themselves and as the preferred means for 
learning diverse subject matter" (Gardner, 1983).

This, I believe to be true. The knowledge that a number of children in one's class hold strong preferences for spatial activity doesn't necessarily dictate a sudden switch to daily art instruction, but may mean allowing these children to operate in various domains using spatial methods. Encouraging youngsters, for instance, to use sketches and diagrams as well as, or instead of, words or numbers to solve math problems; acknowledging and valuing stories told in pictures rather than words; and extending the option of building or drawing story maps to demonstrate reading comprehension. Likewise, it may be helpful to encourage linguistic learners to reason their way through math and spatial problems verbally, and acknowledge that the logical mathematical learners may be more inclined to write factual reports than flights of fiction. For intelligence strength implies not that an individual is only "good at" activities within a specific domain, but simply that he or she may prefer to approach learning tasks through that particular domain. The child who expresses strong preference for linguistic activities and approaches is not doomed to be "bad at" math, but may need help to find linguistic ways to approach mathematical tasks, just as a highly spatial youngster may need to enter the doors of mathematics, reading, and writing through pictures, sketches, diagrams, maps, and charts.

The knowledge that some students prefer to work alone rather than in groups isn't cause to abandon cooperative learning, but it is reason to extend alternatives more frequently. The understanding that many young students prefer to learn expressively is a chance to rejoice and get out the blocks again. In short, knowledge of children's preferences can be used to enrich the curriculum, while students" understanding of their own "best ways" of learning can be used to help them participate in the creation of curriculum more knowledgeably. 
USING INFORMATION GAINED FROM THE CLASSROOM PREFERENCES QUESTIONNAIRE TO ENHANCE ASSESSMENT

With this section, I come back full circle to the issue of assessment, which is where I started in the first place. After watching children go so many directions with Excursions work, I set off in search of a lens, a way to focus my observation and inquiry. The Classroom Preferences Questionnaire, I believe, provides such a lens. The knowledge of children's expressed preferences for particular types of activity, approaches to learning, or modes of social interaction gives me a place to start. I can analyze my own instruction - do my students have enough opportunity to exercise their preferences and demonstrate their strengths; is the environment I provide rich enough to accommodate intelligences other than linguistic and mathematical? I can observe their interactions with materials and other students, looking for signs of preferences. The notion that children express themselves in different ways and approach learning tasks through favored symbol systems has give me new ways to look at their work. Now, in addition to thinking about the mechanics, appearance, and specific content of children's work, I can consider their concerns, whether with the world of objects or the world of people. Do my students bear more resemblance to Gardner's infant patterners or dramatists? Do they tend to approach learning tasks receptively or expressively? This information will impact my observations and the ways I assess children's learning.

A friend of mine frequently asserts that assessment should be part of children's education. By that, she means that children should be engaged in the process of talking and thinking about how they're evaluated in school, and should hopefully have some input. Portfolio assessments and self-evaluation instruments are surely moving in this direction, but I view the Classroom Preferences 
Questionnaire as another way to open dialog in classrooms about what's assessed and how. Writing, drawing, talking, and building are all good ways of demonstrating learning, depending on children's individual preferences for receptive or expressive approaches. Engaging children in discussion about their own "best ways" of showing what they've learned might be a good first step in creating student portfolios or designing assessment of any kind. 


\section{REFERENCES}

Bradford, J. and Schriesheim, C. (1990) Thurscal: A program for interval scaling using paired comparisons or paired comparison treatment of complete ranks under case III assumptions. Educational and Psychological Measurement, 50 (4), 849 - 851.

Brandt, Ron. (1990) On learning styles: A conversation with Pat Guild. Educational Leadership, 48 (2), 10 - 14.

Burk, D., Snider, A., and Symonds, P. (1991) Math Excursions 2. Portsmouth, N.H.:Heinemann Educational Books.

Blythe, T. and Gardner, H. (1990) A school for all intelligences. Educational Leadership, 47.33 - 37.

Dunn, R. and Dunn, K. (1978) Teaching Students Through Their Individual Learning Styles. Reston, Va.: Reston Publishing Company, 1978.

Fagella, K. and Horowitz, J. (1990) Different child, different style. Instructor Magazine, 100, 49 - 54.

Gardner, H. (1983) Frames of Mind. New York: Basic Books.

Gardner, H. and Hatch, T. (1989) Multiple intelligences go to school: Educational implications of the theory of multiple intelligences. Educational Researcher , 18, 4- 10.

Harter, S. (1982) The perceived competence scale for children. Child Development, 53, 87 - 97.

Hatch, T. and Gardner, H. (1986) From testing intelligence to assessing competence: A pluralistic view of intelligence. Roeper Review, 8. 147 - 150.

Hein, G.E., ed. (1990) The Assessment of Hands-On Elementary Science Programs. Grand Forks, N.D.: North Dakota Study Group on Evaluation.

Hyman, R. and Rosoff, B. (1984) Matching learning and teaching styles: The jug and what's in it. Theory Into Practice, 23 (1), 35 - 43. 
Kavale, K and Forness, S. (1987) Substance over style: Assessing the efficacy of modality testing and teaching. Exceptional Children, 56 (3), $228-239$.

Keefe, J. and Ferrell, B. (1990) Developing a defensible learning style paradigm. Educational Leadership, 48 (2), 57 - 60

Langhorst, B. (1989) Assessment in Early Childhood Education: A Consumer's Guide. Portland, Or.: Northwest Regional Educational Laboratory Test Center Evaluation and Assessment.

McCarthy, B. (1990) Using the 4MAT system to bring learning styles to schools. Educational Leadership, 48 (2), 31 - 37.

Moore, W. and Lehmann, D. (1989) A paired comparison nested logit model of individual preference structures. Journal of Marketing Research, 26, 420 - 428.

NAEYC and the National Association of Early Childhood Specialists in State Departments of Education (1991) Guidelines for appropriate curriculum content and assessment in programs serving children ages 3 through 8 . Young Children, 46 (3), 21 - 38.

O'Neil, J. (1990) Making sense of style. Educational Leadership, 48 (2), 4 - 9.

Perrin, J. (1980) Picture Learning Style Inventory. New York: St. John's University.

Sternberg, R. (1990) Intellectual styles: Theory and classroom implications. In:

R. McClure, ed. Learning and Thinking Styles: Classroom Interaction, Washington D.C.: NEA National Center for Innovation.

Sternberg, R. (1988) The Triarchic Mind: A New Theory of Human Intelligence. New York: Viking.

Walters , J. and Gardner, H. (1990) Domain projects as assessment vehicles in a computer-rich environment. (ERIC Document Reproduction Service No. Ed 324367 )

Wexler-Sherman, C., Gardner, H., and Feldman, D. (1988) A pluralistic view of early assessment: The project spectrum approach. Theory Into Practice, 27 (1), $78-83$.

Wolf, D., and Gardner, H. (1980) Style and sequence in early symbolic play. In: K. Rubin, ed. Children's Play. San Francisco: Jossey Bass. 
APPENDIX A

SUMMARY OF CLASSROOM PREFERENCES

QUESTIONNAIRE 
Summary of Classroom Preferences Questionnaire

Preferred Activities

Subject - What are you better at?

- reading

- writing

- math

- art

- science

Tools - Would you rather use

- words

- numbers

- diagrams

- objects

Language - Would you rather write

- a story

- a math story problem

- a set of instructions

Math - Which kind of math problem would you rather do?

- $49+24$

- If each package has 6 hot dog buns, how many packages will we need for 39 people?

Art - Would you rather draw

- a story illustration

- a pattern

- a map

Preferred Methods of Learning

Language - Would you rather

- listen to a story

- read a story

- tell a story

- write a story 
Math - Would you rather work on a math problem by

- figuring it out in your head

- figuring it out on paper

- drawing a sketch or diagram

- using manipulatives

Spatial - Would you rather learn about how something works by

- watching it

- reading about it

- taking it apart

- using it

Spatial - Would you rather work on an invention by

- planning it in your head

- writing about it

- drawing it

- building it

\section{Preferred Mode of Social Interaction}

Social Work Style - Would you rather work

- alone

- with a partner

- with a small group of 3 or 4 children

- together with the whole class

Social Work Orientation - Would you rather write or draw something that's

- your own idea

- your teacher's idea

- an idea you made up with other kids in the class 
APPENDIX B

CLASSROOM PREFERENCES QUESTIONNAIRE 
What are you better at?

\begin{tabular}{lll} 
math & or & reading? \\
\hline science & or & art? \\
\hline writing & or & science? \\
\hline reading & or & writing? \\
\hline science & or & math? \\
\hline art & or & writing? \\
\hline reading & or & art? \\
\hline math & or & writing? \\
\hline art & or & math? \\
\hline reading & or & science?
\end{tabular}

Would you rather use

\begin{tabular}{lll} 
words & or & numbers? \\
\hline objects & or & diagrams? \\
\hline numbers & or & objects? \\
\hline diagrams & or & words? \\
\hline words & or & objects? \\
\hline numbers & & diagrams?
\end{tabular}


Would you rather write

\begin{tabular}{lll} 
a story & or & a math problem? \\
\hline a set of instructions & or & a story? \\
\hline a math problem & or & a set of instructions?
\end{tabular}

Which kind of math problem would you rather do?

$49+24 \quad$ or
If each package has 6 hot dog buns, how many packages will we need for 39 people?

\section{口, 田，正。}

what comes next?
$49+24$

\footnotetext{
If each package has 6 hot dog buns, how many packages will we need for 39 people? 
Would you rather draw

\begin{tabular}{lll} 
a story illustration & or & a pattern? \\
\hline a map & or & a story illustration? \\
\hline a pattern & or & a map?
\end{tabular}

Would you rather

$\begin{array}{lll}\text { read stories or write stories? } & \text { or }\end{array}$

\begin{tabular}{lll}
\hline tell stories & or & listen to stories? \\
\hline write stories & or & tell stories? \\
\hline listen to stories & or & read stories? \\
\hline read stories & or & tell stories? \\
\hline write stories & or & listen to stories?
\end{tabular}


Would you rather work on a math problem by

figuring it out in your

figuring it out on paper?

head

\begin{tabular}{lll}
\hline $\begin{array}{l}\text { drawing a sketch or } \\
\text { diagram }\end{array}$ & or & using manipulatives? \\
\hline figuring it out on paper & or & $\begin{array}{l}\text { drawing a sketch or } \\
\text { diagram? }\end{array}$ \\
\hline
\end{tabular}

\begin{tabular}{lll}
\hline using manipulatives & or & figuring it out on paper?
\end{tabular}

\begin{tabular}{lll}
\hline $\begin{array}{l}\text { figuring it out in your } \\
\text { head }\end{array}$ & $\begin{array}{l}\text { drawing a sketch or } \\
\text { diagram? }\end{array}$ \\
\hline using manipulatives & or & $\begin{array}{l}\text { figuring it out in your } \\
\text { head? }\end{array}$
\end{tabular}

Would you rather learn about how something works by watching it or reading about it?

\begin{tabular}{lll}
\hline taking it apart & or & using it? \\
\hline reading about it & or & taking it apart? \\
\hline using it & or & watching it? \\
\hline watching it & or & taking it apart? \\
\hline reading about it & or & using it?
\end{tabular}


Would you rather work on an invention by

planning it in your head or writing about it?

\begin{tabular}{lll}
\hline drawing it & or & building it? \\
\hline writing about it & or & drawing it? \\
\hline building it & or & planning it in your head? \\
\hline planning it in your head & or & drawing it? \\
\hline writing about it & or & building it?
\end{tabular}

Would you rather work

alone or with a partner?

\begin{tabular}{lll}
\hline $\begin{array}{l}\text { with a small group of } 3 \text { or } \\
4 \text { kids }\end{array}$ & or & $\begin{array}{l}\text { together with the whole } \\
\text { class? }\end{array}$ \\
\hline with a partner & or & $\begin{array}{l}\text { with a small group of } 3 \text { or } \\
4 \text { kids? }\end{array}$ \\
\hline $\begin{array}{l}\text { together with the whole } \\
\text { class }\end{array}$ & or & alone? \\
\hline alone & or & with a small group of 3 or \\
& & $\begin{array}{l}\text { kids? } \\
\text { with a partner }\end{array}$ \\
& or & $\begin{array}{l}\text { together with the whole } \\
\text { class? }\end{array}$
\end{tabular}


Would you rather write or draw something that's

your own idea or

an idea you made up with or

other kids in the class or your teacher's idea?

your own idea? 


\section{APPENDIX C}

PARENT CONSENT FORMS 
May 20, 1992

\section{Dear Parents,}

I am currently doing a project for my master's thesis at Portland State University in which I am investigating children's work style, subject area, and classroom activity preferences. I want to find out whether children prefer to work alone, in partners, with small groups, or with the entire class. I also want to find out about their favorite subjects and activities, and whether their preferences have any bearing on their work in class.

In order to conduct this investigation, I need to interview children, administer a questionnaire about student preferences ${ }^{*}$, and observe students during class work times. I plan to videotape some of the class sessions so I can review them later. I will be the only one to view these tapes. Results of student interviews, questionnaires, and observations will be coded in such a way that children's actual names will not appear in my thesis.

I would like to request permission to involve your child in this study, which will be conducted this term. Your child's participation is strictly voluntary. Failure to participate will not affect grades or school status in any way. Permission to participate may be withdrawn at any time without penalty.

I would greatly appreciate it if you (and your child) would sign the consent forms attached to this letter. Please return one copy to your child's teacher as soon as possible and keep one for your own records. If you have any questions, please feel free to contact me.

Thank you very much.

$$
\text { Sincerely, }
$$

Ms. Allyn Snider

* The items on my questionnaire will solicit information about children's preferred work styles, subject areas, and classroom activities and will be phrased as follows:

Would you rather work alone or with a partner?

Would you rather conduct experiments or design and build things?

Would you rather learn about how something works by watching it or reading about it? 
I voluntarily consent to allow my child to participate in the study described in this letter. I have had the opportunity to ask questions about the project and I understand that I may withdraw my permission to participate at any time. I also understand that failure to participate will not affect my child's grades or school status.

Date 
APPENDIX D

SAMPLE RANKING COMPARISON SHEETS 


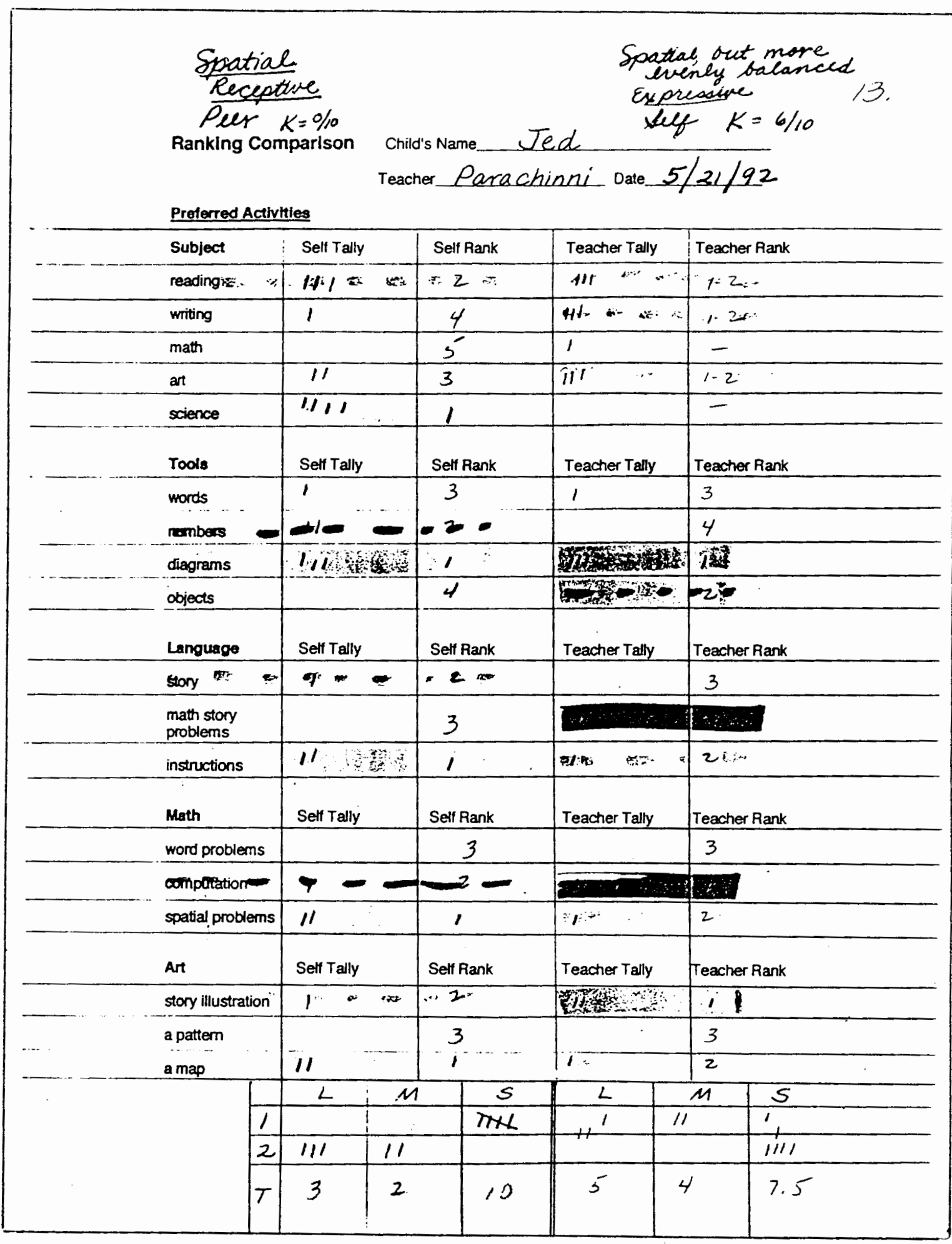


Preterred Level of Abstraction

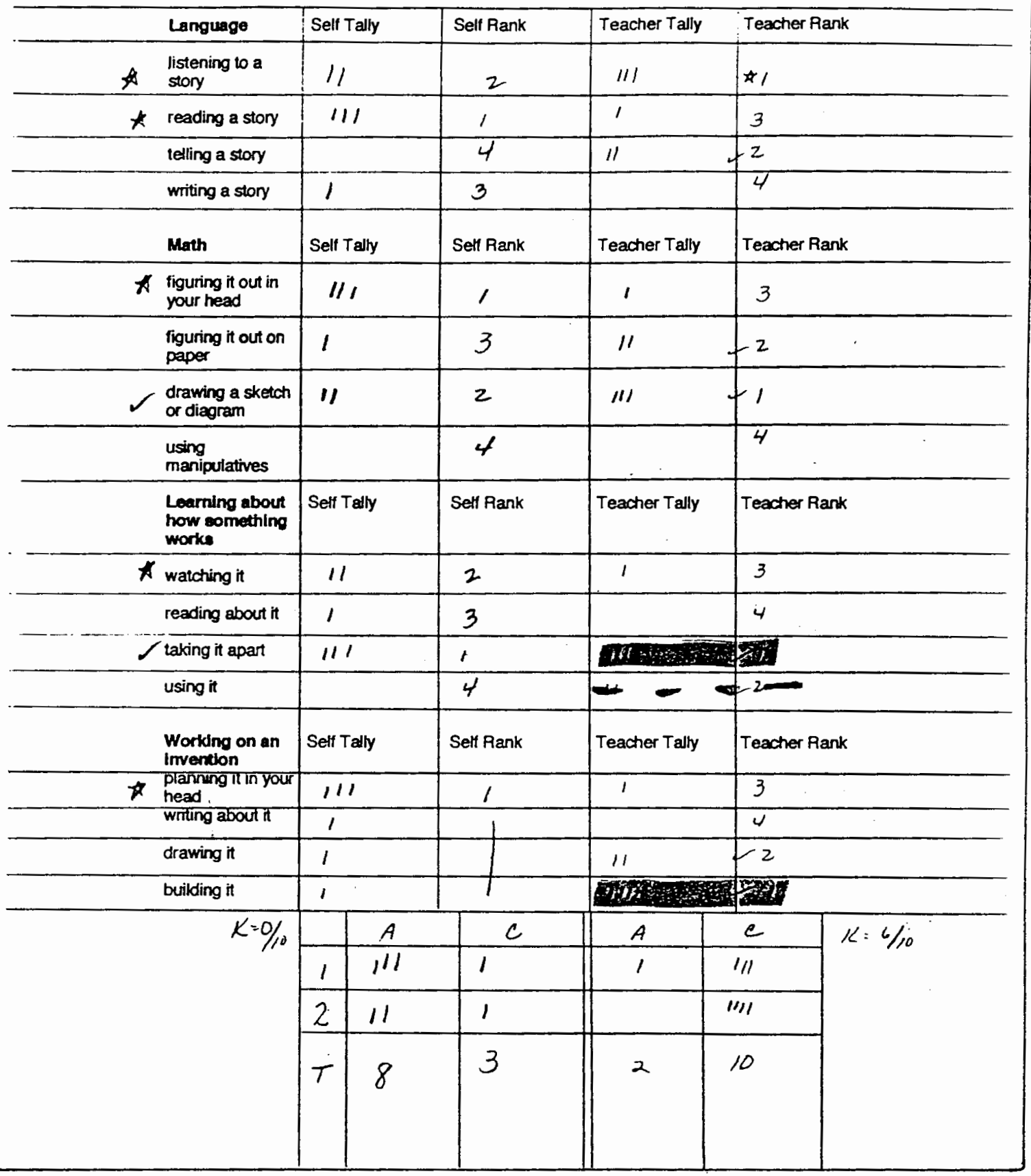


Preferred Level of Social Interaction

\begin{tabular}{|c|c|c|c|c|c|c|}
\hline Rather work & Self Tally & & & Teacher Tally & Teacher Rank & \\
\hline alone & & & & $\pi 1$ & 13 & \\
\hline with a partner & 11 & & & 1 & 3 & \\
\hline $\begin{array}{l}\text { with a small } \\
\text { group }\end{array}$ & 11 & & & $41=$ & tos & \\
\hline $\begin{array}{l}\text { with the whole } \\
\text { group }\end{array}$ & 11 & & & & 4 & \\
\hline $\begin{array}{l}\text { Rather do } \\
\text { something } \\
\text { that'a }\end{array}$ & Self Taily & \multicolumn{2}{|c|}{ Self Rank } & Teacher Tally & \multicolumn{2}{|l|}{ Teacher Rank } \\
\hline your own idea & 1 & \multicolumn{2}{|c|}{2} & $\pi$ & 13 & \\
\hline $\begin{array}{l}\text { your teacher's } \\
\text { rodea }\end{array}$ & & \multicolumn{2}{|c|}{3} & & 3 & \\
\hline 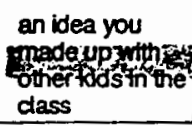 & & & 1 & \multicolumn{2}{|l|}{2} \\
\hline \multirow[t]{4}{*}{$\cdot$} & 5 & $\rho$ & $A$ & 5 & $P$ & $A$ \\
\hline & & 1 & & 11 & & \\
\hline & 1 & $\therefore$ & & & 11 & \\
\hline & 1 & 2 & & 4 & $z$ & \\
\hline
\end{tabular}

